\title{
ASSISTÊNCIA DE ENFERMAGEM MATERNO INFANTIL: APONTAMENTOS AO CUIDADO EM SAÚDE
}

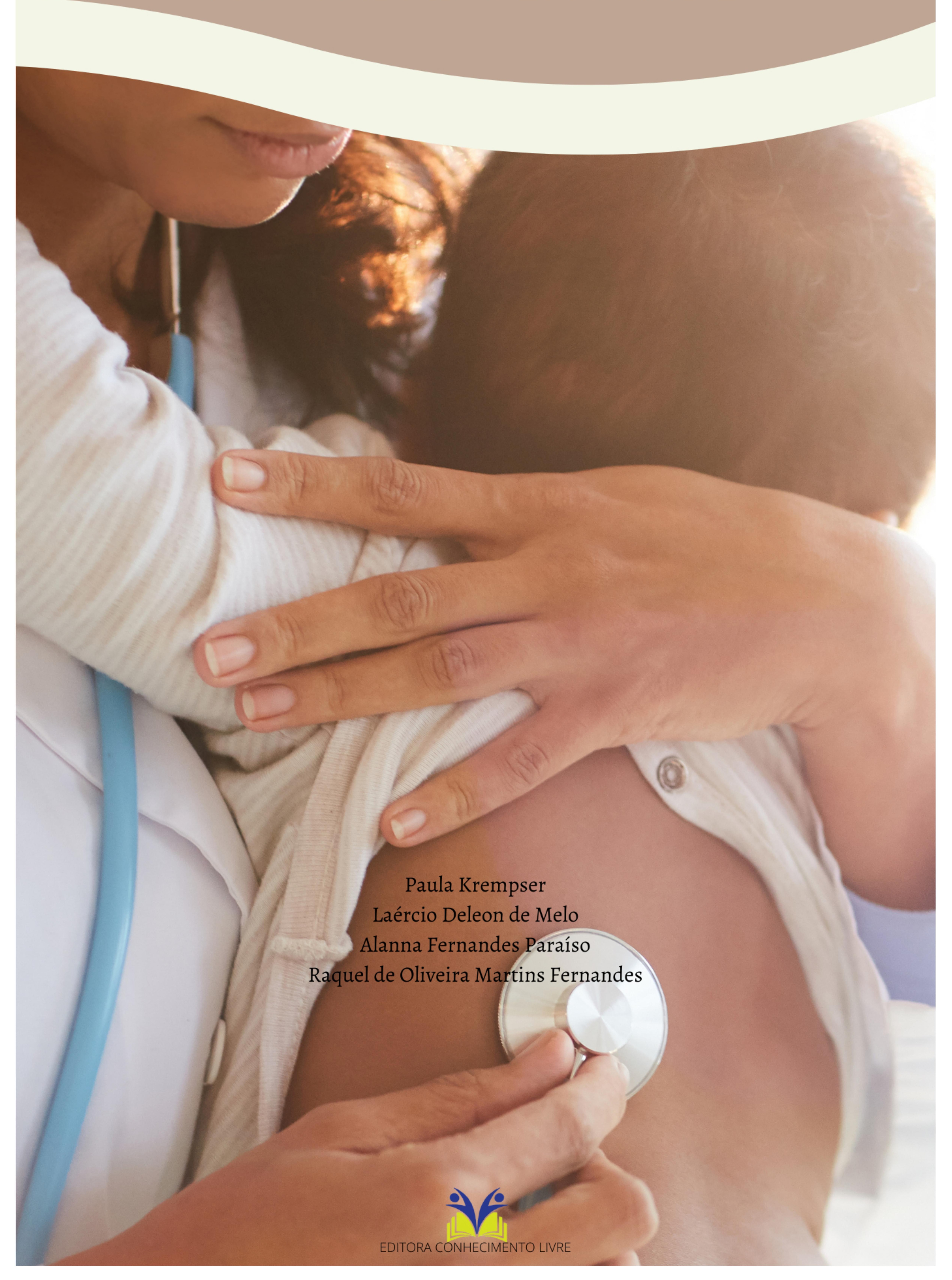




\author{
Paula Krempser \\ Laércio Deleon de Melo \\ Alanna Fernandes Paraíso \\ Raquel de Oliveira Martins Fernandes
}

ASSISTÊNCIA DE ENFERMAGEM MATERNO INFANTIL: APONTAMENTOS AO CUIDADO EM SAÚDE

$1^{\underline{a}}$ ed.

Piracanjuba-GO

Editora Conhecimento Livre

Piracanjuba-GO 
$1^{\mathrm{a}} \mathrm{ed}$

\section{Dados Internacionais de Catalogação na Publicação (CIP)}

Krempser, Paula

K32A ASSISTENCIA DE ENFERMAGEM MATERNO INFANTIL: APONTAMENTOS AO

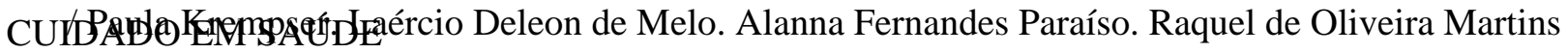

Fernandes. - Piracanjuba-GO

Editora Conhecimento Livre, 2021

89 f.: il

DOI: $10.37423 / 2021$. edcl 321

ISBN: 978-65-89955-51-1

Modo de acesso: World Wide Web

Incluir Bibliografia

1. enfermagem-materno-infantil 2. cateterismo-periférico 3. diabetes-mellitus 4. parto-humanizado

5. aleitamento-materno I. Krempser, Paula II. Melo, Laércio Deleon de III. Paraíso, Alanna

Fernandes IV. Fernandes, Raquel de Oliveira Martins V. Título

https://doi.org/10.37423/2021.edc1321

O conteúdo dos artigos e sua correção ortográfica são de responsabilidade exclusiva dos seus respectivos autores. 


\title{
EDITORA CONHECIMENTO LIVRE
}

\section{Corpo Editorial}

\author{
Dr. João Luís Ribeiro Ulhôa \\ Dra. Eyde Cristianne Saraiva-Bonatto \\ Dr. Anderson Reis de Sousa \\ MSc. Frederico Celestino Barbosa \\ MSc. Carlos Eduardo de Oliveira Gontijo
}

$\underline{\text { MSc. Plínio Ferreira Pires }}$

Editora Conhecimento Livre

Piracanjuba-GO 


\section{SUMÁRIO}

CAPÍTULO 1

PARTO HUMANIZADO: PRÁXIS DO ENFERMEIRO OBSTETRA E MÉTODOS NÃO

FARMACOLÓGICOS PARA O ALÍVIO DA DOR

Aline Carina Pereira de Assis

Paula Krempser

Laércio Deleon de Melo

Alanna Fernandes Paraíso

Isabela Verônica da Costa Lacerda

Milena Limp Mourão Ruffo

Ediane Mendes Lins

Raquel de Oliveira Martins Fernandes

Jéssica Adriana de Paiva

Giane Aparecida Delfino Neves

DOI 10.37423/210804677

CAPÍTULO 2

CUIDADOS DE ENFERMAGEM AO NEONATO PREMATURO E SUA FAMÍLIA DIRECIONADOS AO MÉTODO MÃE CANGURU

Ana Paula Cadette Jorge

Sâmela Fagundes de Oliveira

Paula Krempser

Laércio Deleon de Melo

Alanna Fernandes Paraíso

Isabela Verônica da Costa Lacerda

Giulia Alvim Bassani Silva

Emmanuel Jose Silva de Jesus

Ediane Mendes Lins

Raquel de Oliveira Martins Fernandes

DOI 10.37423/210804678

\section{CAPÍTULO 3}

CUIDADOS DE ENFERMAGEM NO CATETERISMO VENOSO PERIFÉRICO PEDIÁTRICO

Geisa Aisla Sandi Rodrigues Pereira

Paula Krempser

Laércio Deleon de Melo

Alanna Fernandes Paraíso

Isabela Verônica da Costa Lacerda

Giulia Alvim Bassani Silva

Emmanuel Jose Silva de Jesus

Raquel de Oliveira Martins Fernandes

Paulo Henrique Bezerra Silva

Bruno Souza

DOI 10.37423/210804679 
PRÁTICAS DE EDUCAÇÃO EM SAÚDE DESENVOLVIDAS POR ENFERMEIROS SOBRE O

ALEITAMENTO MATERNO EXCLUSIVO

Ana Paula Pedro da Silva

Fabiana dos Santos Clemente Silva

Irene Batista Nascimento

Laís Andrade Monterice

Paula Krempser

Laércio Deleon de Melo

Alanna Fernandes Paraíso

Isabela Verônica da Costa Lacerda

Ediane Mendes Lins

Lara Saber Silva

DOI 10.37423/210804680

\section{CAPÍTULO 5}

ATUAÇÃO DO ENFERMEIRO DA ATENÇÃO PRIMÁRIA NA ASSISTÊNCIA À CRIANÇA COM

DIABETES TIPO 1: FOCO NA QUALIDADE DE VIDA

Ana Carolina de Barros Nunes

Lidia da Dalt Martins Tostes

Luisa Maria Castro de Mendonça

Raquel de Oliveira Martins Fernandes

Laércio Deleon de Melo

Paula Krempser

Alanna Fernandes Paraíso

Jéssica Adriana de Paiva

Felipe Eduardo Taroco

Bruno Souza

DOI 10.37423/210804681 


\section{Capítulo 1}

\section{doi $10.37423 / 210804677$}

\section{PARTO HUMANIZADO: PRÁXIS DO ENFERMEIRO OBSTETRA E MÉTODOS NÃO FARMACOLÓGICOS PARA O ALÍVIO DA DOR}

Aline Carina Pereira de Assis

Paula Krempser

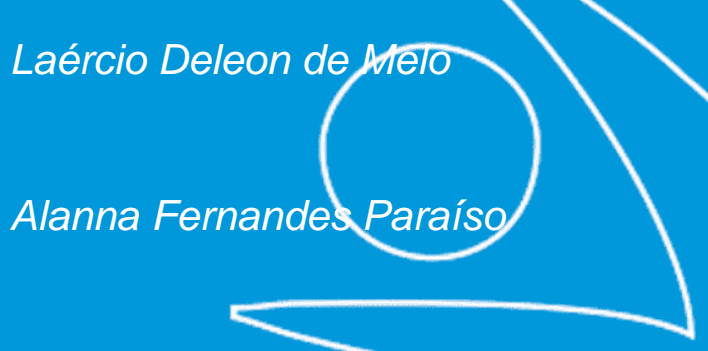

Isabela Verônica da Costa Lacerda

Milena Limp Mourão Ruff

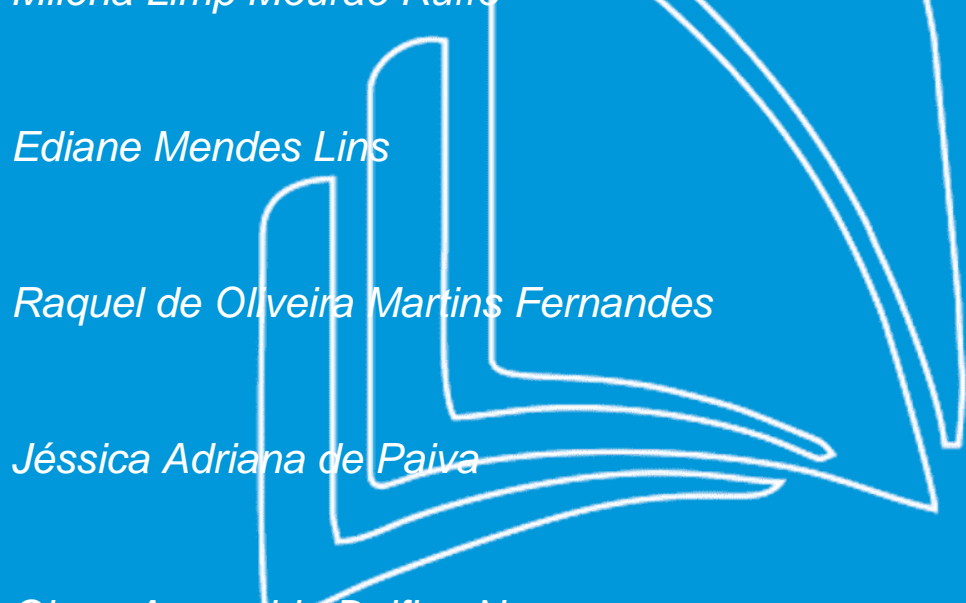

Giane Aparedida Delfino Neves
Centro Universitário Estácio de Juiz de Fora

Universidade Federal de Juiz de Fora

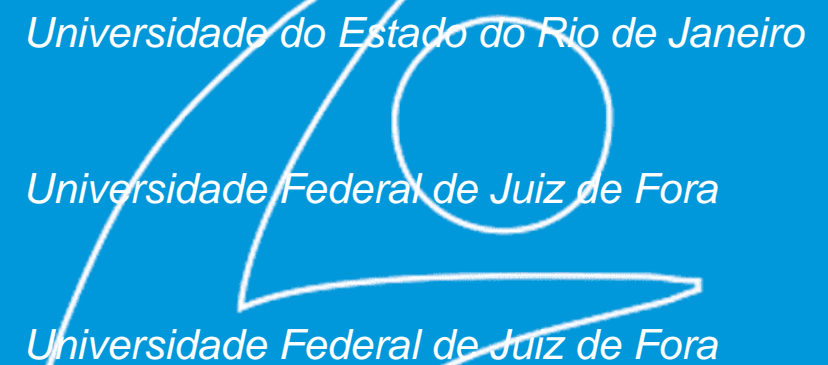

Universidade/Federal de Juiz de Fora

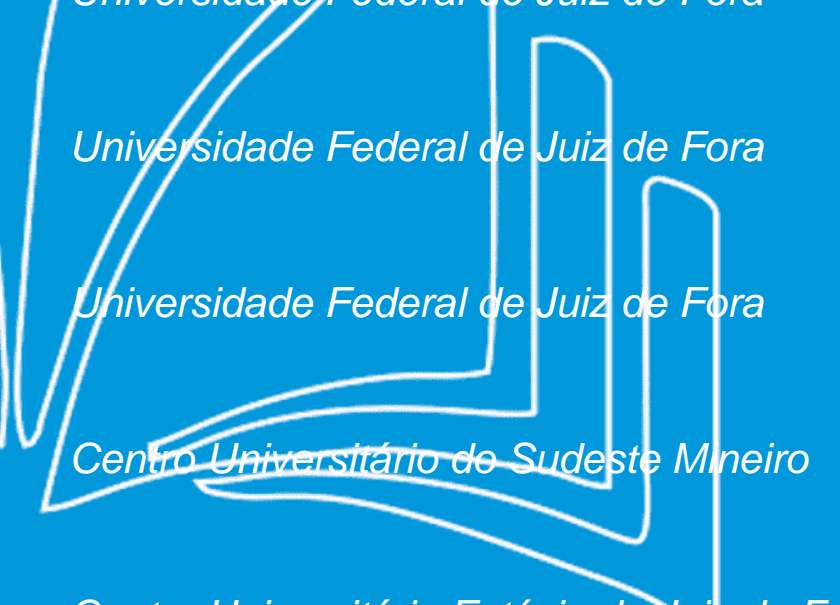

Centro Universitário Estácio de Jtilz de Fora 
Resumo: A dor é inerente ao momento do parto, mas pode ser amenizada através da humanização da assistência de enfermagem com o uso de métodos não farmacológicos de forma a favorecer a vivência do parto normal e fisiológico, conferindo conforto, satisfação emocional, redução da dor e o exercício da tomada compartilhada de decisões. Os objetivos da pesquisa foram identificar os métodos não farmacológicos para alívio da dor no parto, refletir sobre o impacto desses métodos de alívio da dor no parto e analisar a inserção do enfermeiro durante o parto humanizado. Trata-se de pesquisa qualitativa do tipo revisão de literatura. Foram analisados 20 estudos obtidos nas bases de dados eletrônicas SciELO, Lilacs e Bdenf. Para a busca na base de dados, utilizaram-se os descritores: parto humanizado, enfermagem obstétrica, dor do parto, alívio da dor e trabalho de parto em pares. Foram identificados os seguintes métodos não farmacológicos no alívio da dor no parto: hidroterapia, massagem, bola suíça, técnicas respiratórias, deambulação e mudança de posição, crioterapia e acupuntura. A maioria das técnicas se mostram benéficas para amenizar a dor da parturiente no momento do trabalho de parto e proporcionar relaxamento e bem-estar à mulher durante esse processo. Os métodos não farmacológicos e não invasivos de alívio da dor durante o parto se mostram eficazes e são de grande importância para que o enfermeiro obstetra preste uma assistência humanizada.

Palavras-chave: Parto Humanizado. Enfermagem Obstétrica. Dor do parto. Alívio da dor. Trabalho de parto. 


\section{INTRODUÇÃO}

A história do parto no Brasil é acompanhada no modelo hospitalar por procedimentos obstétricos muitas vezes sem a autorização da mulher, como o uso de imobilizações, obrigatoriedade da posição para parir, privação de alimentos e líquidos por via oral, abuso da medicalização para a indução do parto, toques vaginais constantes, tricotomia, privação do contato com familiares e, muitas vezes, uso de distocias como episiotomia e fórceps (CASTRO; ROCHA, 2020).

A Política Nacional de Humanização (PNH), denominada Humanizasus, tem como objetivo redimensionar essa atenção e gestão à saúde por meio da admissão com acolhimento, da atenção integral, da corresponsabilização e do vínculo, da valorização dos usuários, da democratização da gestão e do controle social participativo. No que tange ao Pré-Natal e ao Nascimento, o Ministério da Saúde definiu os princípios dessa atenção, assegurando os direitos de escolha da mulher durante o parto, para que ela receba uma assistência humanizada e de qualidade (PORTO; COSTA; VELLOSO, 2015; BRASIL, 2010; BRASIL, 2015; BRASIL, 2017; LEHUGEUR; STRAPASSON; FRONZA, 2017).

A expressão humanizar, quando se refere à parturiente, engloba uma assistência profissional qualificada, com uso de tecnologias de auxílio à mulher durante o parto, baseada em suas necessidades e em evidências científicas. Visa desmedicalizar o parto associado e respeitar os direitos da paciente, a sua subjetividade, a tomada de decisões, a comunicação efetiva, a inclusão do pai do bebê no parto e a assistência de doulas (LONGO; ANDRAUS; BARBOSA, 2010; BRASIL, 2017; SOUZA; GAIVA; MODES, 2011).

Nesse contexto, o enfermeiro tem uma importante função no período do trabalho de parto, ele incentiva a participação da mulher para que o parto seja vivido por ela ativamente, prestando as informações para o desenvolvimento do parto seguro e compreendendo os fatores que causam medo e insegurança nas parturientes para redimensionar sua assistência de forma integral e humanizada (BENTES; MELO; MARTINS, 2016; DAVIM et al., 2009).

Destarte, a informação fornecida contribui para a diminuição do medo do desconhecido e da ansiedade e, com isso, dá-se a atenuação da sensação de dor. A gestante precisa ser preparada no decorrer da gestação com orientações, a fim de torná-la mais autoconfiante e a experiência de trabalho de parto e parto, menos dolorosa e sem traumas (MEDEIROS et al., 2015; CARRARO et al., 2016). 
A dor do trabalho de parto faz parte da natureza humana e não está associada a patologia, mas sim, à experiência de gerar uma nova vida. Entretanto, algumas mulheres a consideram como a pior dor que se pode sentir e, muitas vezes, superior à sua expectativa, mas a intensidade da dor é influenciada por aspectos comportamentais, temperamentais e culturais, bem como pela constituição genética da mulher e por possíveis desvios da normalidade, como estresse e distocias (KATZER, 2016; GAYESKI; BRÜGGEMANN, 2010).

A aplicação de medidas não farmacológicas para o alívio da dor poderá favorecer o nascimento nas melhores condições possíveis e marcar essa fase como positiva e substituir, na medida do possível, os anestésicos e analgésicos no decorrer do trabalho de parto e parto (MORAES et al., 2010; LOPES et al., 2009; MEDEIRO et al., 2015).

O enfermeiro obstetra tem se destacado por favorecer a vivência do parto normal e fisiológico, respeitando a autonomia e necessidades da mulher, conferindo conforto e satisfação emocional da parturiente durante o trabalho de parto, por meio da redução da dor e do exercício da tomada compartilhada de decisões (REIS et al., 2017; TORAL et al., 2019; ROCHA et al., 2010).

A presente investigação se justifica pelos seguintes argumentos: 1) o parto é um momento único para a mulher e seus familiares; 2 ) o parto é um procedimento que envolve vários profissionais de saúde que devem estar preparados para oferecer um parto humanizado; 3) o alívio da dor pode ser possibilitado por técnicas não farmacológicas condizentes com o parto humanizado e 4) o parto humanizado é incentivado por diversos órgãos de saúde.

Diante do exposto, o objeto de pesquisa são os métodos não farmacológicos utilizados pelo enfermeiro para alívio da dor durante o parto e os objetivos da pesquisa são: identificar os métodos não farmacológicos para alívio da dor no parto, refletir sobre seus impactos na algia da parturiente e analisar a inserção do enfermeiro durante o parto humanizado.

\section{METODOLOGIA}

Pesquisa qualitativa do tipo revisão de literatura que objetivou demonstrar o panorama atual das pesquisas que abordam a temática relacionada ao objeto de pesquisa, os métodos não farmacológicos utilizados pelo enfermeiro para alívio da dor durante o parto, e discuti-los.

A revisão da literatura foi realizada nos meses de março a agosto de 2019 , atualizada em agosto de 2021, com uma pesquisa no portal da Biblioteca Virtual em Saúde (BVS) e no portal da Coordenação de Aperfeiçoamento de Pessoal de Nível Superior (Capes), nas bases de dados Literatura Latino- 
Americana em Ciências de Saúde (Lilacs), Banco de Dados Bibliográficos Especializado na Área de Enfermagem do Brasil (Bdenf), Scientific Electronic Library Online (SciELO) e no Directory of Open Acess Journals (Doaj), no período de 2000 a 2021 (tendo sido 2000 o ano de implementação da humanização do parto).

Para seleção dos estudos, utilizaram-se como critérios de inclusão: artigos completos em português, inglês e espanhol; dissertações e teses de abordagem e que estivessem disponíveis eletronicamente nas bases de dados. Foram critérios de exclusão: as publicações repetidas nas bases pesquisadas, as produções do tipo estudo de caso, artigos de reflexão e de revisão, livros e capítulos de livros e publicações que apresentassem falta de aderência ao tema investigado.

Para a realização da busca, foram utilizados os descritores: "Parto Humanizado", "Enfermagem Obstétrica", "Dor do parto", "Alívio da dor" e "Trabalho de parto" em combinações. Em seguida, foi realizada uma leitura analítica com a finalidade de categorizar as informações contidas nas fontes, de forma que estas possibilitassem a obtenção de respostas ao problema da pesquisa.

Ao combinar os descritores nas bases de dados pesquisadas e aplicados os critérios de inclusão e exclusão, foram encontradas 15 publicações no portal BVS, seis publicações no portal Capes, nove na base de dados Lilacs, seis na base de dados Bdenf, cinco na base de dados SciELO e duas na base de dados Doaj, totalizando 20 estudos.

\section{RESULTADOS E DISCUSSÃO}

As categorias que emergiram da etapa anterior foram analisadas e discutidas a partir do referencial temático do estudo e são apresentadas a seguir.

\subsection{MÉTODOS NÃO FARMACOLÓGICOS NO ALÍVIO DA DOR NO PARTO}

Ao analisar os artigos encontrados sobre a temática, identificamos os seguintes métodos não farmacológicos no alívio da dor no parto: hidroterapia, massagem, bola suíça, técnicas respiratórias, deambulação e mudança de posição, crioterapia e acupuntura.

A hidroterapia é um método que consiste em manter a parturiente no banho por um tempo superior

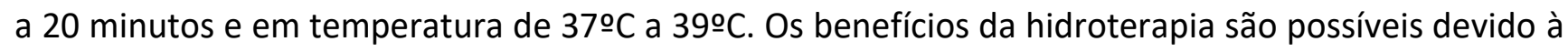
ação do calor ao gerar vasodilatação periférica e consequente relaxamento da musculatura local. Dáse a elevação dos níveis de endorfina e a liberação de catecolaminas, que contribuem para o alívio da 
dor. Esse método possui restrição de uso em mulheres com hipotensão arterial, dado que a água causa vasodilatação (SANTOS, 2018).

Outro método descrito na literatura é a massagem, uma técnica de estimulação sensorial caracterizada pelo toque sistêmico e pela manipulação dos tecidos, feita na região lombar, durante as contrações uterinas e seus intervalos, sendo considerada uma terapêutica simples e de baixo custo (GALLO et al., 2011).

No que tange à bola suíça, também conhecida como bola de parto, bola obstétrica ou bola de Bobath, autores relatam que o posicionamento da mulher em postura vertical permite que a força da gravidade favoreça a mudança de posição e de rotação do bebê para a saída pelo canal da vagina facilmente ao realizar os movimentos para frente e para trás (NASCIMENTO, 2018; BARBIERI et al., 2013).

Outra forma descrita como geradora de benefícios à mulher durante o trabalho de parto é a respiração de forma adequada. É um método simples, de fácil execução e efetivo, que consiste em uma respiração torácica lenta, com inspiração e expiração profundas e longas em um ritmo natural, sendo realizada e priorizada no momento das contrações uterinas. Para maior efetividade, recomenda-se que sejam feitos os exercícios de respiração no período expulsivo, pois podem promover o relaxamento e a mulher pode se sentir no controle de seu próprio corpo. Cabe ressaltar que essa técnica não deve ser iniciada antecipadamente para evitar hiperventilação da gestante. Apesar de benéfica, essa técnica pode não ser suficiente na redução da sensação dolorosa durante o primeiro estágio do trabalho de parto (SILVA et al., 2013; GALLO et al., 2011; MASCARENHAS et al., 2019).

A técnica de mudança de posição e deambulação durante o processo do parto também é descrita na literatura como capaz de aliviar a dor do parto. Nessa técnica, a parturiente é incentivada a se mover com frequência, alterando o assento entre cadeira e leito em decúbito lateral, agachada, ajoelhada, em pé com inclinação de tronco, em quatro apoios e demais posições de acordo com as habilidades motoras de cada paciente (SANTOS, 2018; NASCIMENTO, 2018).

A crioterapia, outro método encontrado na literatura, consiste na utilização de compressas ou cintas de gelo, aplicadas sobre a região lombar, em decúbito lateral esquerdo, por um período de tempo de 20 minutos. O uso da técnica pode amenizar a dor durante a fase ativa e o período expulsivo, podendo reduzir o tempo do parto (SILVA et al., 2013; MASCARENHAS et al., 2019). 
Ao analisar os estudos encontrados sobre métodos não farmacológicos para alívio da dor à parturiente no trabalho de parto, foram identificadas a aromaterapia e a musicoterapia como métodos que precisam ser mais estudados para indicação de seu uso (GAYESKII; BRÜGGEMANN, 2010; SILVA et al., 2013; OSÓRIO; SILVA JR.; NICOLAU, 2013).

A aromaterapia é descrita como método alternativo, de fácil aplicação e baixo custo, que se utiliza do efeito da essência das plantas. O mecanismo de ação ainda é desconhecido, mas parece estimular a produção de substâncias relaxantes, estimulantes e sedativas, que são próprias do corpo humano (GAYESKII; BRÜGGEMANN, 2010).

Ao analisar a musicoterapia, identifica-se na literatura que se trata de uma ciência que estuda os efeitos terapêuticos da música nos seres humanos. É um método de baixo custo e de fácil empregabilidade, porém possui avaliações conflitantes no que se refere à efetividade no alívio da dor (SILVA et al., 2013; OSÓRIO; SILVA JR.; NICOLAU, 2013).

\subsection{IMPACTO DOS MÉTODOS NÃO FARMACOLÓGICOS}

O banho quente, ao longo do trabalho de parto, proporciona relaxamento e alívio da dor. Outro benefício do banho é propiciar à mulher bem-estar durante o processo de nascimento, ele revitaliza, reduz o desconforto das contrações e resulta na dilatação cervical (SANTOS, 2018).

O calor intensifica a circulação sanguínea, atenuando o estresse provocado pelas contrações, e, em contato com alguns tecidos, melhora o metabolismo e a elasticidade amenizando a dor. Os resultados da terapia com banho quente revelaram que a ansiedade diminuiu significativamente (BARBIERI et al., 2013).

Já ao avaliar a técnica de massagem lombossacral, foram relatadas contribuições durante o trabalho de parto ao reduzir a dor, diminuindo os níveis de estresse emocional e melhorando o fluxo sanguíneo e a oxigenação dos tecidos (GALLO et al., 2011).

Apesar de benéfica, estudos divergem apontando que a massagem não muda os traços da dor das parturientes, porém ela é efetiva em duas das três fases da dilatação do colo uterino, a aceleração e inclinação máxima, ajudando a aliviar a intensidade da dor nas mesmas (DAVIM; TORRES; DANTAS, 2009). Esse método diminui as reações comportamentais e a ansiedade, visto que, para muitas pessoas, não há nada mais confortável e relaxante que o contato pele a pele (SOUZA; AGUIAR; SILVA, 2015). 
Ao avaliar os benefícios de exercícios feitos com a bola, encontram-se indicações de eficácia significativa na redução da dor, progresso durante o trabalho de parto, com aumento das contrações uterinas. Seu uso na fase ativa do trabalho de parto é mais satisfatório, sendo capaz de reduzir o período de dilatação, facilitar a circulação materno-fetal, auxiliar na descida e insinuação da apresentação do feto, diminuir as taxas de trauma perineal e episiotomia e ainda permite que a mulher assuma diferentes posições (BARBIERI et al., 2013).

Outra técnica analisada foram os exercícios respiratórios, que são relatados em estudos como capazes de reduzir a ansiedade, promover relaxamento, melhorar os níveis de saturação de oxigênio maternos e garantir à mulher que participe ativamente do processo de parturição e autonomia no controle da dor, sem causar efeitos colaterais (SILVA et al., 2013). Estudos mostram também que essa técnica proporciona baixo nível de ansiedade por maior tempo no processo parturitivo, bem-estar físico e emocional (MAFETONI; SHIMO, 2014).

A movimentação e a deambulação são favoráveis e contribuem para o alívio da dor, pois retiram o foco álgico da mulher e incentivam, por exemplo, sua ida ao chuveiro para o banho de ducha, melhorando a progressão do parto (MAFETONI; SHIMO, 2014). Outro benefício identificado na movimentação da parturiente é a estimulação da circulação materno-fetal e, quando na posição ereta, a gravidade auxilia a descida do feto, aumentam as frequências e intensidade das contrações (NASCIMENTO, 2018; SANTOS, 2018).

A deambulação tem maior influência sobre a duração do trabalho de parto nas três primeiras horas da fase ativa do período de dilatação, ou seja, quanto mais as parturientes deambularem nessas três horas do início da fase ativa do parto, maiores serão os benefícios percebidos para diminuir a duração do trabalho de parto (MORAES et al., 2010).

Ao analisar a aplicação de cinta com gelo, Silva et al. (2011), em seu estudo, relatam que algumas mulheres dormiram durante o uso ou pediram que não fosse retirada. Outra contribuição identificada, além do alívio da dor, foi a diminuição da exaustão, da ansiedade, do estresse e o enfrentamento das contrações durante o período de dilatação do colo uterino até a expulsão do feto pelo fato de o resfriamento promover a liberação de endorfina e favorecer o relaxamento muscular (NUNES; VARGENS, 2007).

Segundo Gayeskii e Brüggemann (2010), a aromaterapia foi o método menos avaliado acerca do alívio da dor, sendo assim, é necessária a realização de mais estudos para examinar os seus efeitos durante o trabalho de parto. Já a musicoterapia durante o trabalho de parto pode intervir no ciclo vicioso 
medo-tensão-dor de maneira relaxante e, consequentemente, minimizar a dor (SILVA et al., 2013). Já segundo estudo de Osório, Júnior e Nicolau (2013), há relatos de que a musicoterapia não impacta significativamente o alívio da dor.

\subsection{ATUAÇÃO DO ENFERMEIRO NO PARTO HUMANIZADO}

O enfermeiro e sua equipe, durante o trabalho de parto, devem se dedicar a auxiliar a gestante ao longo desse processo, respeitando o seu tempo, e utilizar técnicas que visam aliviar a dor e a ansiedade, como hidroterapia, exercícios respiratórios, massagens, deambulação, uso da bola obstétrica e mudança de posição (SILVA et al., 2016).

O enfermeiro obstetra desempenha seu papel com métodos não invasivos no cuidado de enfermagem, promovendo uma assistência embasada no respeito quanto à fisiologia do processo do parto e nascimento. Nesse caso, o enfermeiro exerce sua função de forma humanizada, com qualidade e consegue desenvolver as práticas de cuidado que fornecem benefícios tanto para a mãe quanto para o recém-nascido. Faz uso das práticas de cuidado para proporcionar conforto e ajudar durante o trabalho de parto, parto e nascimento e encoraja as mulheres a perceberem seus corpos com autonomia ao longo do parto (RAMOS et al.,2015).

Silva, Costa e Pereira (2011), em seu estudo, mostraram que os enfermeiros implementam as práticas de cuidado humanizado que possuem evidências científicas das vantagens. Os cuidados devem prezar pela cidadania das mulheres e os profissionais devem entender que o parto, para a mulher que o experiencia, é uma vivência relacionada à dor e ao medo. Dessa forma, pode-se favorecer a qualificação da assistência ao parto como experiência humana dignificante e prazerosa, cumprindo o enfermeiro obstetra uma importante função nesse processo.

O enfermeiro obstetra deverá ouvir as expectativas da gestante para o processo de parturição, mantendo um ambiente tranquilo, que facilite a liberdade da mulher e proporcione o uso de métodos não farmacológicos no alívio da dor. Essas práticas têm um papel fundamental para que a parturiente tenha um trabalho de parto e parto com conforto e de forma menos traumática (MAFETONI; SHIMO, 2014).

O cuidado da enfermagem pautado na humanização do parto normal está inserido na política de humanização e principalmente, no uso de métodos que proporcionam bem-estar, conforto e proteção para a mulher durante o trabalho de parto. O enfermeiro obstetra possui autonomia profissional e 
assim pode utilizar métodos únicos, ou em conjunto, que sejam capazes de reduzir a dor do parto, sendo eles não invasivos ou não farmacológicos (NASCIMENTO, 2018).

\section{CONSIDERAÇÕES FINAIS}

O parto humanizado precisa ser implementado, em razão do fato de possibilitar à mulher o poder de escolha, fazendo com que esta seja protagonista nesse processo, com respeito à sua privacidade, promovendo segurança, bem-estar e conforto, pautados em uma assistência de qualidade, com apoio familiar nesse momento único e especial da mulher.

Os métodos não farmacológicos identificados têm o intuito de reduzir a dor e proporcionar uma experiência positiva para a mulher. As técnicas de hidroterapia, massagem, bola suíça, exercícios respiratórios, deambulação e movimentação se mostram eficazes e benéficas no alívio da dor nas parturientes, além de reduzirem a duração do trabalho de parto, a ansiedade, o medo e proporcionarem relaxamento e bem-estar à gestante, com diminuição das distocias e dos efeitos colaterais de fármacos.

Existem métodos citados na literatura, como aromaterapia e musicoterapia, para os quais ainda não foram comprovados os benefícios de redução da dor durante o trabalho de parto e parto. Portanto, tais métodos necessitam ser mais estudados para indicação no alívio álgico da parturiente.

O enfermeiro é um profissional determinante durante o trabalho de parto por desempenhar o cuidar respeitando os aspectos fisiológicos, emocionais e socioculturais e elegível para inserir os métodos não farmacológicos para humanização do parto, objetivando uma experiência menos dolorosa, com autonomia e protagonismos da parturiente a respeito de seu parto.

A presente investigação tem como limite a busca por estudos que abordam técnicas para o alívio da dor da mulher durante o parto, mostrando a necessidade de se conhecer outros cuidados que contribuam para humanização do parto, bem-estar da mulher e autonomia nesse momento. Sugerese que novos estudos acerca de crioterapia, aromaterapia, musicoterapia e acupuntura sejam realizados para contribuir na inclusão de novos métodos não farmacológicos que busquem a redução da dor da parturiente e seus demais benefícios. 


\section{REFERÊNCIAS}

BARBIERI, Márcia et al. Banho quente de aspersão, exercícios perineais com bola suíça e dor no trabalho de parto. Acta paul. enferm. [online]. 2013, v.26, n.5, p.478-484. Disponível em: <http://dx.doi.org/10.1590/S0103-21002013000500012>. Acesso em 13 de maio de 2019.

BENTES, Natália Fernanda da Silva; MELO, Queize Nascimento de; MARTINS, Tays da Silva. A humanização da assistência de enfermagem durante o trabalho de parto na maternidade Mãe Luzia. Revista Eletrônica Estácio Saúde. 2016; v. 5, n.1. Disponível em <http://revistaadmmade.estacio.br/index.php/saudesantacatarina/article/viewFile/2225/1049> Acesso em 05 de maio de 2019.

BRASIL. Ministério da Saúde. Secretaria de Ciência, Tecnologia e Insumos Estratégicos. Departamento de Gestão e Incorporação de Tecnologias em Saúde. Diretrizes nacionais de assistência ao parto normal: versão resumida [recurso eletrônico] / Ministério da Saúde, Secretaria de Ciência, Tecnologia e Insumos Estratégicos, Departamento de Gestão e Incorporação de Tecnologias em Saúde. - Brasília : Ministério da Saúde, 2017. 51 p. : il.

BRASIL. Ministério da Saúde. Secretaria de Atenção à Saúde. Política Nacional de Humanização. HumanizaSUS: documento base para gestores e trabalhadores do SUS. Brasília (DF): MS; 2010.

CARRARO, Telma Elisa et al. Cuidado e conforto durante o trabalho de parto e parto: na busca pela opinião das mulheres. Texto contexto - enferm., Florianópolis, v. 15, n. spe, p. 97-104, 2006. Disponível em <http://dx.doi.org/10.1590/S0104-07072006000500011>. Acesso em 04 de maio de 2019.

CASTRO, Antonia Tainá Bezerra; ROCHA, Sibele Pontes. Violência obstétrica e os cuidados de enfermagem: reflexões a partir da literatura. Enfermagem em Foco, [S.I.], v. 11, n. 1, jun. 2020. ISSN 2357-707X. Disponível

em: <http://revista.cofen.gov.br/index.php/enfermagem/article/view/2798/725>. Acesso em: 05 ago. 2021. doi:https://doi.org/10.21675/2357-707X.2020.v11.n1.2798.

DAVIM, Rejane Marie Barbosa; TORRES, Gilson de Vasconcelos; DANTAS, Janmilli da Costa. Efetividade de estratégias não farmacológicas no alívio da dor de parturientes no trabalho de parto. Revista da Escola de Enfermagem da USP, 2009; v. 43, n. 2, p. 438-445. Disponível em <https://dx.doi.org/10.1590/S0080-62342009000200025>. Acesso em 18 de março de 2019.

GALLO, Rubneide Barreto Silva et al. Recursos não farmacológicos no trabalho de parto: protocolo assistencial. Femina. 2011 jan; v. 39, n. 1. Disponível em <http://files.bvs.br/upload/S/01007254/2011/v39n1/a2404.pdf>. Acesso em 06 de maio de 2019.

GAYESKI, Michele Edianez; BRÜGGEMANN, Odaléa Maria. Métodos não farmacológicos para alívio da dor no trabalho de parto: uma revisão sistemática. Texto \& Contexto - Enfermagem, 2010, v. 19, n. 4, p. 774-782. Disponível em <https://dx.doi.org/10.1590/S0104-07072010000400022>. Acesso em 13 de maio de 2019.

GONÇALVES, Juliana Josefa Araújo. A prática da Acupuntura para o alívio da dor no trabalho de parto normal: revisão sistemática de literatura. Monografia, como exigência parcial e obrigatória para conclusão do Curso de Medicina da Faculdade de Medicina da Bahia (FMB), da Universidade Federal 
da Bahia (UFBA) 2018. Disponível em: <https://repositorio.ufba.br/ri/handle/ri/28877> acesso em: 17 de maio de 2019.

LEHUGEUR, Danielle; STRAPASSON, Márcia Rejane; FRONZA, Edegar. Manejo não farmacológico de alívio da dor em partos assistidos por enfermeiras obstétricas. Rev. enferm. UFPE on line, Recife, v. 11, n. 12 p. 4929-37, 2017. DOI: https://doi.org/10.5205/1981-8963-v11i12a22487p4929-4937-2017.

LONGO, Cristiane Silva Mendonça; ANDRAUS, Lourdes Maria Silva; BARBOSA, Maria Alves. Participação do acompanhante na humanização do parto e sua relação com a equipe de saúde. Rev. Eletr. Enf. [Internet]. 2010 abr./jun.; v. 12, n. 2, p. 386-91. Disponível em: <http://dx.doi.org/10.5216/ree.v12i2.5266>. Acesso em 06 de maio de 2019.

LOPES, Caroline Vasconcellos et al. Experiências vivenciadas pela mulher no momento do parto e nascimento de seu filho. Cogitare enferm. 2009; v. 14, n. 3, p. 484-90. Disponível em: <http://revistas.ufpr.br/cogitare/article/view/1617 8/10697 2>. Acesso em 06 de maio de 2019.

MAFETONI, Reginaldo Roque; SHIMO, Antonieta Keiko Kakuda. Métodos não farmacológicos para alívio da dor no trabalho de parto: Revisão Integrativa. Rev. Min. Enfermagem. 2014; v. 18, n, 2, p. 513-520. Disponível em: <http://www.reme.org.br/artigo/detalhes/942>. Acesso em: 13 de maio de 2019.

MASCARENHAS, Victor Hugo Alves, et al. Evidências científicas sobre métodos não farmacológicos para alívio a dor do parto. Acta Paul Enferm. 2019;32(3):350-7. Disponível em: https://www.scielo.br/j/ape/a/QPfVQVTpmczQgjL783B9bVc/?format=pdf\&lang=pt. Acesso em: 08 de agosto de 2021.

MEDEIROS, Juliana et al. Métodos não farmacológicos no alívio da dor de parto: percepção de puérperas. Rev Espaço para a Saúde. 2015; v. 16, n. 2, p. 37-44. Disponível em: <http://www.uel.br/revistas/uel/index.php/espacoparasaude/article/view/20717> Acesso em 05 de maio de 2019.

MORAES, Maísa Suares Teixeiras, et al. Applicability of non-pharmacological strategies for pain relief in Parturient: integrative review. Rev. Enferm. UFPE [online]. 2010; v. 4, n. Spe. Disponível em: <https://periodicos.ufpe.br/revistas/revistaenfermagem/article/view/6260/5507>. Acesso em: 07 de maio de 2019.

MOURA, Fernanda Maria de Jesus S. Pires et al. A humanização e a assistência de enfermagem ao parto normal. Rev. bras. enferm. [online]. 2007, v.60, n.4, pp.452-455. ISSN 0034-7167. Disponível em: <http://dx.doi.org/10.1590/S0034-71672007000400018>. Acesso em 16 de maio de 2019.

NASCIMENTO, Nalva da Silva. Atuação do enfermeiro no parto normal humanizado: benefícios de métodos não invasivos para alívio da dor. Artigo científico (Bacharelado). - Centro Universitário São Lucas. Porto Velho, 2018. Disponível em:

<http://repositorio.saolucas.edu.br:8080/xmlui/handle/123456789/2907>. Acesso em: 13 de maio de 2019.

NUNES, Sonia; VARGENS, Octavio Muniz da Costa. O Uso do Gelo para Alívio da Dor no Cuidado à Parturiente: Revisão integrativa. Rev.Enfermagem obstétrica, setembro, 2014, pp. 95-99. Disponível em:<www.enfo.com.br/ojs/index.php/EnfObst/article/view/22> Acesso em 28 de maio de 2019. 
NUNES, Sonia; VARGENS, Octavio Muniz da Costa. A crioterapia como estratégia para alívio da dor no trabalho de parto: um estudo exploratório. Rev. enferm. UERJ; 15(3): 337-342, jul.-set. 2007. Disponível em: <www.facenf.uerj.br/v15n3/v15n3a03.pdf> Acesso em 28 de maio de 2019.

OSORIO, Samara Maria Borges; SILVA JR, Lourival Gomes da; NICOLAU, Ana Izabel Oliveira. Avaliação da efetividade de métodos não farmacológicos no alívio da dor do parto. Rev Rene [online] 2014, v. 15 (janeiro-fevereiro). Disponível em: <http://www.redalyc.org/articulo.oa?id=324030684022>. Acesso em 20 de maio de 2019.

PORTO, Any Alice Silva; COSTA, Lucília Pereira da; VELLOSO, Nádia Aléssio. Humanização da assistência ao parto natural: uma revisão integrativa. Rev. Ciência e Tecnologia. 2015;v. 1, n. 1, p. 12-19. Disponível

em:<http://revistaeletronica.unicruz.edu.br/index.php/CIENCIAETECNOLOGIA/article/view/284/528 >. Acesso em 07 de maio de 2019.

RAMOS WMA, AGUIAR BGC, CONRAD D, et al. Contribuição da enfermeira obstétrica nas boas práticas da assistência ao parto e nascimento. Rev Fund Care Online. 2018 jan./mar.; 10(1):173-179. Disponível em: < http://dx.doi.org/10.9789/2175-5361.2018.v10i1.173-179> Acesso em 25 de maio de 2019.

REIS, Thamiza Laureany da Rosa dos et al. Autonomia feminina no processo de parto e nascimento: revisão integrativa da literatura. Rev Gaúcha Enferm. 2017 mar; v. 38, n. 1:e64677. Disponível em: <http://dx.doi.org/10.1590/19831447.2017.01.64677>. Acesso em 16 de maio de 2019.

ROCHA, Ana Maria, MONTEIRO, Cláudia Sofia C.B.C; FERREIRA, Manuela; DUARTE, João. Cuidados no alívio da dor: perspectiva da parturiente. Rev. Millenium. 2010; v. 38, p. 299-309. Disponível em: <www.ipv.pt/millenium/Millenium38/20.pdf>. Acesso em 07 de maio de 2019.

SILVA, Dannielly Azevedo de Oliveira et al. Uso de métodos não farmacológicos para o alívio durante o trabalho de parto normal: revisão integrativa. Rev enferm UFPE, Recife, v. 7, n.(esp):4161-70, maio, 2013.

em:<http://www.revista.ufpe.br/revistaenfermagem/index.php/revista/article/viewFile/258 2/pdf_2608>. Acesso em 13 de maio de 2019.

SILVA, Eveline Franco da; STRAPASSON, Márcia Rejane; FISCHER, Ana Carla dos Santos. Métodos não farmacológicos de alívio da dor durante trabalho de parto e parto. R. Enferm. UFSM, 2011 Mai/Ago; v. 1, n. 2, p. 261-271. Disponível em: <https://periodicos.ufsm.br/reufsm/article/view/2526> acesso em 13 de maio de 2019.

SILVA, Taís Folgosa da; COSTA, Guilherme Augusto Barcello; PEREIRA, Adriana Lenho de Figueiredo. Cuidados de enfermagem obstétrica no parto normal. Cogitare enferm; 16(1): 82-87, jan.-mar. 2011. Disponível em: <https://revistas.ufpr.br/cogitare/article/view/21116> Acesso em 25 de maio de 2016.

SILVA, Ursula et al. O cuidado de enfermagem vivenciado por mulheres durante o parto na perspectiva da humanização. Rev Enferm UFPE. 2016;10(4):1273-9. Disponível em: <http://revista.cofen.gov.br/index.php/enfermagem/article/view/1318> Acesso em 25 de maio de 2019. 
SANTOS, Rosemary Alves Ramos dos. Métodos não farmacológico de alívio de dor durante o parto humanizado. 2018. 31f. Trabalho de Conclusão de Curso de Enfermagem - Faculdade Anhanguera, Santa Bárbara d’Oeste, 2018. Disponível em:

<https://repositorio.pgsskroton.com.br/bitstream/123456789/22265/1/ROSEMARY_+ALVES_RAMO S_DOS_+SANTOS+-+ATIVIDADE+DEFESA.pdf>. Acesso em 06 de maio de 2019.

SOUZA, Émilin Nogueira Silva e; AGUIAR, Maria Geralda Gomes; SILVA, Bianka Sousa Martins. Métodos não farmacológicos no alívio da dor: equipe de enfermagem na assistência a parturiente em trabalho de parto e parto. Rev. Enfermagem Revista v.18, n. 02, maio/ago. 2015. Disponível em: <http://periodicos.pucminas.br/index.php/enfermagemrevista/article/view/11693> . Acesso em 17 de maio de 2019.

SOUZA, Taísa Guimarães de; GAÍVA, Maria Aparecida Munhoz; MODES, ANJOS, Priscilla Shirley Siniak dos. A humanização do nascimento: percepção dos profissionais de saúde que atuam na atenção ao parto. Rev Gaúcha Enferm., Porto Alegre (RS) 2011 set; v. 32, n. 3, p. 479-86. Disponível em: <http://dx.doi.org/10.1590/S1983-14472011000300007>. Acesso em 07 de maio de 2019.

TORAL et al. Assistência De Enfermagem Na Humanização Do Parto: Uma Revisão Integrativa. Rev. Eletrônica Estácio Saúde, v. 8, n. 1, 2019. Disponível em:

<http://revistaadmmade.estacio.br/index.php/saudesantacatarina/article/view/5358>. Acesso em: 13 de maio de 2019. 


\section{Capítulo 2}

\section{doi $10.37423 / 210804678$}

\section{CUIDADOS DE ENFERMAGEM AO NEONATO PREMATURO E SUA FAMÍLIA DIRECIONADOS AO MÉTODO MÃE CANGURU}

Ana Paula Cadette Jorge

Sâmela Fagundes de Qliveira

Paula Krempser

\section{Laércio Deleon deMelo}

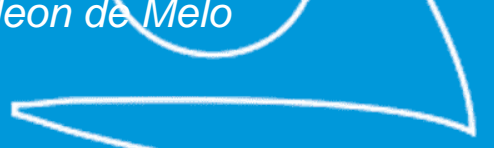

Alanna Fernandes Paraíso

Isabela Verônica da Coste Lacerds

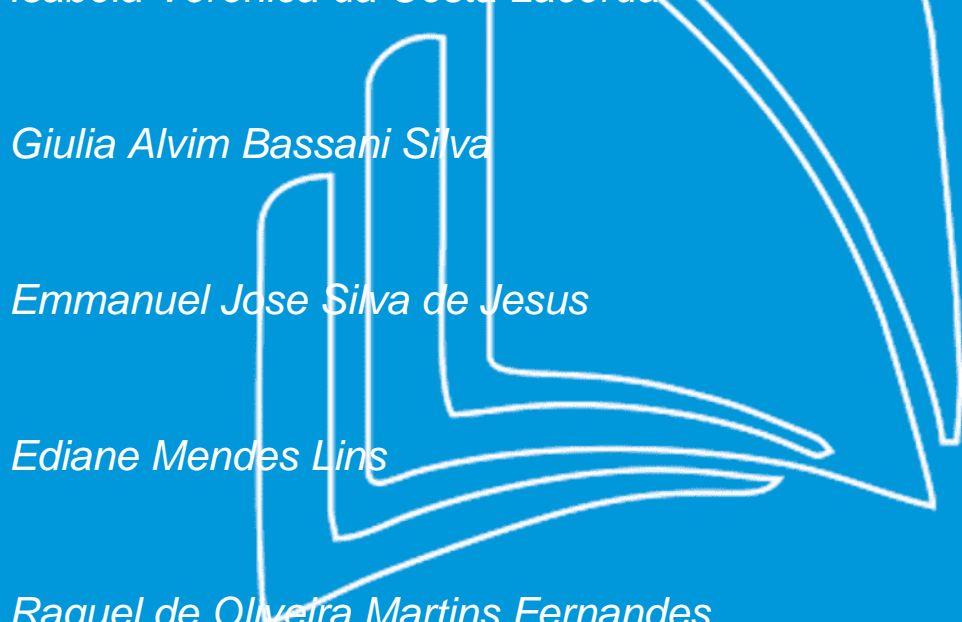

Centro Universitário Estácio de Juiz de Fora

Centro Universitário Estácjo de Juiz de Fora

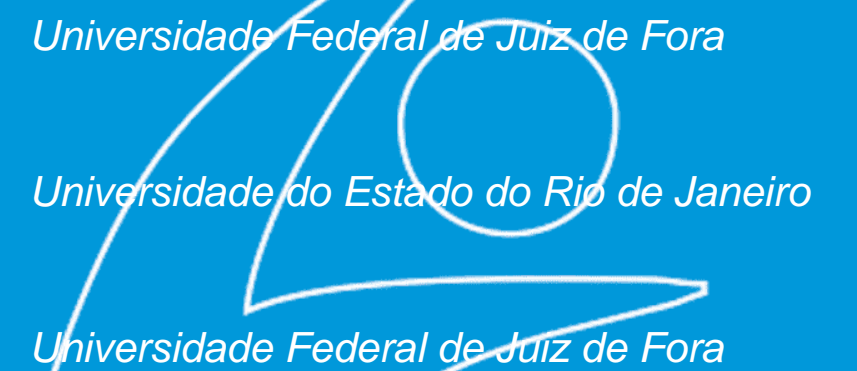

Raquel de Olveira Martins Fernandes 


\section{Resumo:}

Introdução: o Ministério da Saúde tem tido como foco principal a redução da mortalidade infantil e a diminuição do tempo de internação de prematuros. Para minimizar esse problema, lançou o Método Canguru, sendo este uma assistência neonatal voltada para o atendimento do recém-nascido prematuro, que implica colocar o bebê em contato pele a pele com sua mãe. Objetivou-se conhecer os benefícios e os desafios experienciados por profissionais de saúde acerca do Método Canguru. Realizou-se uma revisão de literatura de artigos indexados nas bases de dados: BVS, Capes, Scielo, Lilacs e Bdenf, no período de 2015 a 2021, tendo sido as buscas realizadas entre os meses de agosto a outubro de 2019 e atualizadas em agosto de 2021. Desenvolvimento: foram incluídos oito artigos que possibilitaram a formação das categorias: 1) a prematuridade e o Método Canguru, que apresentou os critérios de prematuridade e as indicações clínicas do Método Canguru; 2) benefícios do uso do Método Canguru e as atribuições do enfermeiro neonatologista, que descreveu as principais vantagens dessa terapêutica e as funções precípuas do enfermeiro. Considerações finais: os benefícios do método incluem a estabilização fisiológica como a frequência cardíaca; diminuição da dor e do choro da criança; auxílio no ganho de peso e na busca pela amamentação e sucção; formação de um vínculo afetivo entre mãe e RN; maior participação do enfermeiro e sua equipe durante a terapêutica. Como desafios assumem maior importância o medo da mãe de tocar na criança, às vezes pelo fato de esta estar ligada a aparelhos e a baixa adesão do pai à terapêutica.

Palavras-chave: Método Canguru. Família. Cuidados de Enfermagem. Recém-Nascido Prematuro. Relações Enfermeiro-Paciente. 


\section{NTRODUÇÃO}

As políticas públicas nacionais voltadas para a saúde materna e infantil vêm sendo articuladas e progressivamente construídas em nosso país. O Método Canguru (MC) surgiu no mundo na década de 70 e no Brasil começou a ser utilizado na década de 90, porém, somente no ano de 2000 , foi promulgada a Portaria MS/GM 693, e publicada a norma de atenção humanizada ao Recém-Nascido (RN) de baixo peso como uma estratégia de atendimento mais humanizado ao neonato prematuro, a fim de favorecer um contato precoce com a mãe e a família e seus cuidados (BRASIL, 2017; BRASIL, 2015).

Denominada "Mãe Canguru", a proposta consiste em colocar precocemente o RN de baixo peso em contato com a mãe pele a pele de forma contínua. Esse método foi idealizado na Colômbia, no ano de 1979, no Instituto Materno Infantil de Bogotá, pelos médicos Reys Sanabria e Hector Martinez, com objetivo de melhorar os cuidados prestados ao RN pré-termo, diminuir os custos da assistência perinatal e promover o vínculo afetivo mãe-RN, a estabilidade térmica, o desenvolvimento infantil e a alta hospitalar precoce (BRASIL, 2015).

No Brasil, o MC sempre foi utilizado como um cuidado diferenciado, visando à qualidade da assistência. Ao completar 15 anos de política no país, destaca-se, além da redução da mortalidade, uma série de vantagens evidenciadas em publicações científicas, entre elas um melhor desenvolvimento neuropsicomotor ao abranger cuidados técnicos com o bebê como cuidados com luz, som, dor, acolhimento à família (BRASIL, 2015).

Atualmente, o MC é uma política de saúde pública incorporada e atrelada às várias estratégias que visam à redução da mortalidade infantil, tais como: Pacto pela Redução da Mortalidade Infantil no Nordeste e na Amazônia Legal e, recentemente, a Rede Cegonha (BRASIL, 2017).

Importante também observar que, tendo em vista a necessidade de avaliar essa nova proposta de atenção, o Ministério da Saúde (MS), em 2005, financiou um estudo que verificou que as unidades canguru tiveram desempenho nitidamente superior em relação ao aleitamento materno exclusivo na alta hospitalar $(69,2 \%$ versus $23,8 \%$ ) e aos 3 meses após a alta, além de menores percentuais de reinternação $(9,6 \%$ versus $17,1 \%)$. Dessa forma, a estratégia de humanização adotada pelo MS é a maneira mais segura e moderna de tratamento e uma boa estratégia para a promoção do aleitamento materno (BRASIL, 2015). 
A adoção dessa estratégia contribuiu para a promoção de uma mudança institucional na busca da atenção à saúde materno-infantil, centrada em evidências científicas que garantem qualidade, humanização e o princípio de cidadania da família, além de aumentarem as chances de vida de RNs, sendo possível assim um suporte a esse grupo etário, voltado para suas necessidades biológicas, ambientais e familiares (BRASIL, 2017).

A atuação assistencial no MC começa numa fase prévia ao nascimento de um RN pré-termo e/ou de baixo peso, com a identificação das gestantes com riscos e com orientações voltadas aos cuidados específicos com suporte psicológico. Após o nascimento, com necessidade de permanência na Unidade de Terapia Intensiva Neonatal (UTI-N) e/ou de Cuidados Intermediários (UCI), é estimulada a entrada dos pais na unidade, para o estabelecimento do vínculo com seu RN e estimulação do contato direto, pele a pele, com o RN sempre que possível e desejado, de forma precoce, gradual, segura e agradável. $\mathrm{O}$ estímulo à lactação/amamentação e a participação dos pais nos cuidados do bebê também são prioridades (BRASIL, 2015).

Após a estabilidade clínica da criança, com ganho de peso regular e fortalecimento de segurança, interesse e disponibilidade da mãe, esta pode participar dos cuidados ao RN e permanecer com a criança o maior tempo desejado. Na alta hospitalar, é necessário o seguimento ambulatorial criterioso do RN e de sua família até a criança atingir 2.500g. Nessa etapa, há todo esse acompanhamento por uma equipe multiprofissional capacitada para a atenção humanizada ao RN de baixo peso (BRASIL, 2015).

A equipe de enfermagem é o grupo de profissionais que estão presentes em toda rotina a ser feita pelo $M C$, incluindo a família do neonato. A equipe deve construir um plano de cuidado terapêutico singular para cada RN e para família deste, acolhê-los de forma mais humanizada, para fazer as devidas orientações para mãe, pai e a família do RN durante todo o período de internação hospitalar, além de oferecer suporte e apoio aos pais nos diferentes momentos e espaços da unidade neonatal. Além disso, deve desenvolver ações educativas em saúde com a família, oferecendo atividades ocupacionais para as mães durante o período de permanência hospitalar junto ao filho internado. A equipe, por meio desse cuidado humanizado, pode promover ações que tornem o ambiente mais tranquilo, a fim de proporcionar mais conforto ao RN de baixo peso, bem como realizar as devidas orientações à família na alta hospitalar, reforçando a comunicação com a equipe hospitalar e a atenção básica (BRASIL, 2015). 
Diante do exposto, justifica-se a realização da pesquisa devido à necessidade e à importância da utilização do método mãe canguru como forma de promover o estabelecimento do vínculo RN-família, a recuperação do $\mathrm{RN}$, melhoria das condições de vida extrauterina e diminuição do número de mortalidade de prematuros antes do primeiro ano de vida. Justifica-se ainda pela necessidade de entender também a relação dos profissionais de enfermagem com a família do RN, já que o enfermeiro é o profissional que convive a maior parte do tempo com as famílias das crianças e desenvolve vínculo com elas, estando apto para propagar, incentivar e orientar O MC, esclarecendo suas etapas e as dúvidas da família do RN sempre que for necessário.

Os cuidados de enfermagem ao neonato prematuro e à família deste direcionados pelo $\mathrm{MC}$ foram o objeto desta investigação. Sendo assim, o objetivo foi descrever as atribuições do enfermeiro e sua equipe em relação ao uso do $\mathrm{MC}$ nos cuidados ao RN prematuro e à família deste.

Para uma atenção mais humanizada, o enfermeiro deve promover educação em saúde, que precisa ser desenvolvida em todos os momentos de assistência prestada na inclusão do método, nas visitas de enfermagem, permitindo a convivência dos familiares do RN com a família de outros neonatos, para que possam compartilhar experiências vividas de histórias parecidas. O enfermeiro deve ainda prestar uma assistência integral, assumindo o seu de papel cuidador, uma vez que o cuidado é a essência da enfermagem. Sendo assim, o enfermeiro toma para si toda a responsabilidade de orientações à família do neonato e encontra certas dificuldades na realização do Método Canguru $\mathrm{Na}$ rotina hospitalar, em todos os procedimentos. O enfermeiro deve sempre incentivar o aleitamento materno, pois é um dos principais motivos do elo entre mãe e RN.

Este estudo tem abordagem qualitativa do tipo revisão de literatura e objetivou apresentar o panorama atual das pesquisas que tratam da temática relacionada ao objeto de pesquisa e discutir sobre elas. A revisão da literatura foi realizada nos meses de agosto a outubro de 2019 e atualizada em agosto de 2021, nas bases de dados: Biblioteca Virtual em Saúde (BVS) e no portal da Coordenação de Aperfeiçoamento de Pessoal de Nível Superior (Capes), Literatura Latino-Americana em Ciências de Saúde (Lilacs), Banco de Dados Bibliográficos Especializado na Área de Enfermagem do Brasil (Bdenf) e na Scientific Electronic Library Online (SciELO) no período de 2015 a 2021.

Para seleção dos estudos, utilizaram-se como critérios de inclusão: artigos completos em português, inglês e espanhol; dissertações e teses; disponíveis eletronicamente nas bases de dados para acesso gratuito. Foram critérios de exclusão: as publicações repetidas nas bases pesquisadas; delineamentos 
do tipo estudo de caso, artigos de reflexão, livros e capítulos de livros e publicações que apresentassem falta de aderência ao tema investigado.

Para a realização da busca, foram utilizados os descritores: "Método Canguru"; "Família"; "Cuidados de Enfermagem"; "Recém-Nascido Prematuro" e "Relações Enfermeiro-Paciente" em combinação por pares. Posteriormente foi realizada uma leitura analítica com a finalidade de categorizar as informações contidas nas fontes, e estas possibilitaram a obtenção de respostas ao problema da pesquisa.

\section{DESENVOLVIMENTO}

Ao combinar os descritores nas bases de dados pesquisadas, foram encontradas 228 publicações, sendo incluídas oito destas (seis da Lilacs e duas da Bdenf), conforme apresentado no Quadro 1.

Quadro 1- Panorama atual das pesquisas que abordam os cuidados de enfermagem ao neonato prematuro e a sua família fundamentados no Método Canguru segundo base de dados, periódico, título do artigo e autores de acordo com critérios de seleção.

\begin{tabular}{|c|c|c|c|}
\hline $\begin{array}{c}\text { BASE } \\
\text { DE } \\
\text { DADOS }\end{array}$ & REVISTA & $\begin{array}{l}\text { TÍTULO DO } \\
\text { ARTIGO }\end{array}$ & AUTORES \\
\hline Lilacs & $\begin{array}{l}\text { Rev. Enferm. } \\
\text { UFPE on-line }\end{array}$ & $\begin{array}{l}\text { Fortalecimento do } \\
\text { vínculo entre a } \\
\text { família e o } \\
\text { neonato } \\
\text { prematuro }\end{array}$ & Sousa et al. 2019. \\
\hline $\begin{array}{l}\text { Lilacs, } \\
\text { Bdenf - } \\
\text { Enfermage } \\
\text { m }\end{array}$ & $\begin{array}{l}\text { Rev. Pesqui. cuid. } \\
\text { fundam. (On-line); }\end{array}$ & $\begin{array}{l}\text { Benefícios do } \\
\text { Método Canguru: } \\
\text { uma revisão } \\
\text { integrativa }\end{array}$ & Zirpoli et al. 2019. \\
\hline $\begin{array}{l}\text { Bdenf - } \\
\text { Enfermagem }\end{array}$ & $\begin{array}{l}\text { Rev. Enferm. UFPE } \\
\text { on-line; }\end{array}$ & $\begin{array}{l}\text { O valor atribuído } \\
\text { pelos profissionais } \\
\text { de enfermagem aos } \\
\text { cuidados } \\
\text { preconizados pelo } \\
\text { Método Canguru }\end{array}$ & Stelmak et al. 2017 \\
\hline $\begin{array}{l}\text { Bdenf - } \\
\text { Enfermagem }\end{array}$ & Rev. Enferm. UFSM & $\begin{array}{l}\text { Método Canguru: } \\
\text { Benefícios e } \\
\text { desafios } \\
\text { experienciados por } \\
\text { profissionais de } \\
\text { saúde }\end{array}$ & Gesteira et al. 2016 \\
\hline $\begin{array}{l}\text { Lilacs, Bdenf } \\
\text { Enfermagem }\end{array}$ & $\begin{array}{l}\text { Rev. Eletrônica } \\
\text { Enferm; }\end{array}$ & $\begin{array}{l}\text { Posição canguru em } \\
\text { recém-nascidos pré- } \\
\text { termo de muito } \\
\text { baixo peso: estudo } \\
\text { descritivo }\end{array}$ & Farias et al. 2017 \\
\hline
\end{tabular}




\begin{tabular}{|c|c|c|c|}
\hline Lilacs & $\begin{array}{l}\text { Rev. Bras. Ciênc. } \\
\text { Saúde }\end{array}$ & $\begin{array}{l}\text { Métodos } \\
\text { alternativos de } \\
\text { alimentação do } \\
\text { recém-nascido } \\
\text { prematuro: } \\
\text { considerações e } \\
\text { relato de } \\
\text { experiência }\end{array}$ & Pessoa et al. 2016 \\
\hline Lilacs & $\begin{array}{l}\text { Revista } \\
\text { Enfermagem UFSM }\end{array}$ & $\begin{array}{l}\text { Método canguru: } \\
\text { percepções da } \\
\text { equipe de } \\
\text { enfermagem em } \\
\text { terapia intensiva } \\
\text { neonatal }\end{array}$ & Mantelli et al. 2017 \\
\hline $\begin{array}{l}\text { Lilacs, Bdenf } \\
\text { E } \\
\text { Enfermagem }\end{array}$ & Rev. Rene (On-line) & $\begin{array}{l}\text { Cuidado centrado } \\
\text { na família e sua } \\
\text { prática na unidade } \\
\text { de terapia intensiva } \\
\text { neonatal }\end{array}$ & Rodrigues et al. 2019 \\
\hline
\end{tabular}

A seguir, são apresentadas as categorias emergidas da análise dos artigos selecionados nas bases de dados, a saber: 1) a prematuridade e o Método Canguru; 2) benefícios do uso do Método Canguru e as atribuições do enfermeiro neonatologista.

\section{A PREMATURIDADE E O MÉTODO CANGURU}

A prematuridade de RN é considerada para aqueles nascimentos que ocorram na idade gestacional (IG) inferior a 37 semanas e com peso menor que $2.500 \mathrm{~g}$ (baixo peso), menor que $1.500 \mathrm{~g}$ (muito baixo peso) ou menor que 1.000g (extremo baixo peso). Segundo a Organização Mundial de Saúde (OMS), no mundo, há 15 milhões de recém-nascidos pré-termo (RNPTs), o que se torna um problema para a saúde pública. A ocorrência no Brasil é de 279 mil partos prematuros a cada cem nascimentos de crianças vivas por ano, totalizando uma taxa de 9,2\% dos partos (SOUZA et al., 2019).

Pode-se assim considerar prematuro limítrofe o RN com uma idade gestacional de 36 semanas e 36 dias, o que leva a um estado de alto risco, podendo desenvolver sérios problemas, como instabilidade fisiológica e alterações metabólicas. Ao nascerem nessas condições, necessitam de um cuidado mais especializado. Possuem um peso relativo entre $2.200 \mathrm{~g}$ e $2.800 \mathrm{~g}$, medem entre 45 e $46 \mathrm{~cm}$ de comprimento e aproximadamente $32,5 \mathrm{~cm}$ de perímetro cefálico (SOUZA et al., 2019).

Já os RNs com prematuridade moderada possuem mais de $2.000 \mathrm{~g}$ de peso, o que leva a uma baixa mortalidade e diminuição de óbitos. Há também os RNs de prematuridade extrema, que possuem 
idade gestacional menor que 30 semanas, grau alto de imaturidade, intercorrências mais graves, aumentando riscos de deficiência. Possuem uma faixa de peso de $1.500 \mathrm{~g}$, com uma estatura menor ou igual a $38 \mathrm{~cm}$ e menos de $29 \mathrm{~cm}$ de perímetro cefálico (BRASIL, 2017).

Os RNPTs precisam de internação em Unidade de Terapia Intensiva Neonatal (UTIN) e Unidade de Cuidados Intermediários (UCl) para estabilização hemodinâmica e alcance de peso satisfatório a ponto de ser possível sua alta hospitalar. Nesse contexto, ocorre a separação de família, mãe e filho, o que pode comprometer o vínculo afetivo familiar e dificultar a aproximação dos familiares ao novo membro da família, uma vez que são parcial ou totalmente privados de ver e tocar o bebê, assim como de falar com ele e cuidar-lhe[L1] durante esse período (SOUZA et al., 2019).

Dessa forma, os profissionais de saúde precisam acolher a mãe do RN e os familiares, proporcionar condições para participação ativa dos pais nos cuidados ao filho, favorecendo o vínculo afetivo. O MC é considerado uma estratégia de atenção humanizada ao RNBP, voltada a auxiliar na reversão dessa realidade (SOUZA et al., 2019).

Com os avanços da qualidade dos cuidados intensivos na área neonatal, aliados a uma assistência multiprofissional humanizada, os índices de morbimortalidade dos RNPTs vêm diminuindo a cada ano e isso impacta a qualidade de vida dessas crianças, mas a prematuridade ainda constitui a principal causa de mortalidade neonatal (BRASIL, 2017).

Em todo o mundo, nascem 15 milhões de prematuros a cada ano, sendo que o Brasil se encontra entre os dez primeiros países onde ocorre o maior número de nascimentos. O baixo peso, associado à prematuridade, é responsável por cerca de $60 \%$ a $80 \%$ das mortes neonatais. Além disso, outro desfecho é o comprometimento no desenvolvimento neurológico das crianças que sobreviverem (SOUZA et al., 2019).

O uso tecnológico e especializado na assistência ao RNPT e ao RN, de peso inferior a 2.500 e $1500 \mathrm{~g}$ respectivamente, tem possibilitado a diminuição do índice de mortalidade perinatal e neonatal. O RN de baixo peso e o prematuro precisam de assistência neonatal especializada, e a utilização do MC está listada como uma das três intervenções prioritárias mais eficientes no atendimento ao RNPT. Evidência na redução da morbimortalidade e sepse (BRASIL, 2017).

A equipe de enfermeiros deve estar atenta na UTIN para promover o desenvolvimento do fortalecimento do vínculo entre a família e o RN, motivando-a a realizar a troca de fraldas e a alimentar 
o RN, assim como conversar com ele e a tocá-lo. Além disso, oportunizar aos pais do RN o conhecimento do MC para que possam praticá-lo com o filho. (SOUSA et al., 2019).

$\mathrm{O}$ MC consiste em um contato pele a pele precoce dos RNPTs e de baixo peso em uma posição de decúbito ventral junto ao peito da mãe. Ele pode ser realizado não somente pela mãe, mas também pelo pai ou familiares próximos, o que gerou a troca de sua nomenclatura. A denominação "mãe canguru" foi substituída por "Método Canguru" pelo fato de outros membros da família estarem aptos a realizá-lo também (ZIRPOLI et al., 2019; GESTEIRA et al., 2016).

Esse contato promove a estabilidade clínica do RN a partir do momento que é iniciado, e o neonato permanece junto da mãe como se estivesse numa bolsa, semelhante a um canguru. Esse contato, toque pode proporcionar também ao neonato menos períodos de apneia, aumento ponderado de peso e bom funcionamento do sistema nervoso central. Esse método terapêutico usado na assistência de crianças prematuras nessas internações de unidades neonatais faz com que os RNs fiquem menos tempo em incubadoras até o alcance do peso considerado para alta. A longa permanência deles traz riscos não só para o bebê, como para a mãe também, pois aumenta a chance de infecções por conta da internação prolongada na unidade (GESTEIRA et al., 2016).

O Método Canguru é composto de três etapas, a saber: a primeira inicia-se no pré-natal, quando da identificação de uma gestação de alto risco, e é continuado na Utin até alta hospitalar do RN; a segunda etapa vai ocorrer de forma contínua numa pré-alta hospitalar, em que a mãe é estimulada a cuidar do seu filho, permanecendo por mais tempo nesse contato pele a pele e a terceira vai ocorrer em casa ou em ambulatório até o alcance de 2,5kg pelo RN (ZIRPOLI et al., 2019; GESTEIRA et al., 2016).

A primeira etapa se inicia no pré-natal durante a gestação, com orientações dos cuidados especializados durante todo o parto e o nascimento, seguidas da possível necessidade de internação do RN na UTI neonatal, da rotina da unidade, dos cuidados de lavagem das mãos, da importância da presença dos avós e dos irmãos como forma de acolher os pais e a família (BRASIL, 2017).

A segunda etapa passa a ser realizada na unidade de Cuidados Intermediários Canguru (Ucinca), com todos os processos de cuidados iniciados na primeira etapa, além do aleitamento materno. Logo o RN permanece junto à mãe, na posição canguru. A equipe deve garantir à puérpera a permanência na unidade hospitalar, oferecendo o suporte assistencial necessário, além de propiciar o contato pele a pele precoce, respeitando as condições clínicas do RN e a disponibilidade de aproximação e interação dos pais com o bebê. Para realização dessa etapa, o neonato necessita de estar com uma boa estabilidade, além de estar em nutrição enteral plena e com mínimo de peso de $1.250 \mathrm{~g}$. Em relação à 
mãe, é necessário que tenha conhecimentos e habilidades, além de disponibilidade para realizar o MC (BRASIL, 2017).

Na terceira etapa, o RNBP recebe alta da unidade hospitalar e deve ser acompanhado em casa pela equipe do hospital e pela unidade de atenção básica do MC. Para efetivação dessa etapa, o neonato necessita de peso mínimo de $1.600 \mathrm{~g}$. É de extrema importância que a mãe esteja sempre segura, motivada e bem orientada para realizar esse cuidado domiciliar ao RN. A equipe de saúde deve garantir atendimento na unidade hospitalar de origem, a qualquer momento, até a alta da terceira etapa, além de assegurar acompanhamento ambulatorial do RN até que ele atinja o peso de $2.500 \mathrm{~g}$ (BRASIL, 2017).

\section{BENEFÍ́CIOS DO USO DO MÉTODO CANGURU E AS ATRIBUIÇÕES DO ENFERMEIRO} NEONATOLOGISTA

O Método Canguru traz inúmeros benefícios não só para o neonato, mas também para os pais. Deve ser realizado de maneira orientada, segura e acompanhada de suporte assistencial por uma equipe de Saúde adequadamente capacitada (ZIRPOLI et al., 2019).

Pode-se destacar como benefício desse método um maior ganho de peso de forma acelerada devido à termorregulação possibilitada pela troca de calor entre a pele do RN e da/do mãe/pai. O método também contribui para a diminuição do choro e do estresse da criança, além da melhora do sono devido a esse contato, uma vez que a criança se sente mais segura junto à pele da/do mãe/pai. 0 neonato tende a ficar mais tranquilo e calmo, pois a agitação neuropsicomotora é reduzida devido a esse contato pele a pele (ZIRPOLI et al., 2019; GESTEIRA et al., 2016). Outro benefício relatado na literatura é a diminuição da incidência de infecção hospitalar pelo neonato, menor tempo no oxigênio e melhor resposta ao tratamento, com recuperação e alta precoce (STELMAK et al., 2017).

Ambos são beneficiados com o método, pois a permanência dos familiares durante a internação do RN na unidade de tratamento aumenta o vínculo afetivo e a confiança entre mãe, pai e familiares e o $\mathrm{RN}$, com formação da identidade materna e paterna. Além disso, estabelece-se a corresponsabilização pelo cuidado do RN com a equipe de saúde (ZIRPOLI et al., 2019; GESTEIRA et al., 2016).

O contato aumentado com a mãe incentiva também o aleitamento materno, ao fortalecer o estado emocional da mãe, contribui para a "descida do leite", aumentado pela frequência da sucção e, consequentemente, eleva as chances de sucesso na amamentação e diminui as intercorrências. Além 
disso, ao perceber e sentir o carinho e afeto dos pais, o $\mathrm{RN}$ tende a recuperar-se mais rápido, aumentando as chances de alta da UTI (ZIRPOLI et al., 2019; GESTEIRA et al., 2016).

A importância do $M C$ se prende a um de seus principais benefícios, fortalecer os laços afetivos entre o neonato e a mãe e/ou pai, visto que o vínculo entre eles foi rompido no momento do nascimento do bebê antes da hora. A equipe deve estar sempre presente, para incentivar a família a consolidar esse vínculo (SOUZA et al., 2019).

Sabe-se que a gravidez é um momento especial para a mulher, ao se tornar mãe, ela já começa a imaginar os momentos a serem vivenciados, a lidar com as mudanças pelas quais o corpo passa e com o bebê em seu ventre, e este passa a ter uma boa participação da vida da mãe. Ela espera uma gravidez tranquila, sem intercorrências durante a gestação, mas nem sempre isso acontece, pode ocorrer um parto prematuro, ou seja, a criança nasce antes do tempo previsto. Essa chegada antes da hora acaba gerando outros sentimentos, como medo, insegurança nos pais e familiares. Essa separação não planejada entre mãe e filho acaba gerando uma ruptura no elo afetivo, que foi sendo construído durante toda a gravidez. Com essa quebra, a mãe pode se sentir culpada, e aquele sentimento que unia a mãe ao filho pode se arrefece (FARIAS et al., 2017).

Para que os pais se sintam mais seguros, é necessário que a equipe de enfermagem estabeleça uma boa relação com eles, deixando-os mais confiantes em relação ao quadro clínico de seu filho, esclarecendo, na medida do possível, todas as dúvidas, assim diminuindo a ansiedade em relação à recuperação do RN. O enfermeiro é o elo da aproximação da família com o bebê (SOUZA et al., 2019).

A equipe de enfermagem tem papel fundamental em encorajar os pais a tocarem na criança e a retomarem esse vínculo afetivo, incentivando-os na aplicação do Método Canguru, com as devidas orientações relacionadas ao esclarecimento de todas as etapas, e apoiando a família sempre que necessário (SOUZA et al., 2019).

O enfermeiro deve atuar de forma dedicada, carinhosa e respeitosa, considerando que as famílias de RNs prematuros se encontram fragilizadas, por verem a criança tão esperada em um ambiente cheio de aparelhos e equipamentos, com risco de morte. Nesse sentido, o enfermeiro deve ser empático com toda a família, trabalhando de forma eficiente e eficaz para prestar uma assistência digna e de qualidade. O enfermeiro pode elaborar estratégias para uma prática mais humanizada, visando fortalecer o vínculo entre a mãe e o neonato (SOUZA et al., 2019). 
Outro benefício que comprova a eficácia do Método Canguru na assistência trazida pelo enfermeiro é a oportunidade de aproximação deste com o paciente, além do estabelecimento de vínculo mãe e filho. Também se constrói uma ligação entre enfermeiro, mãe e bebê. Essa aproximação da tríade profissional-família-criança é elemento crucial para a recuperação do RN, proporcionando à mãe segurança para cuidar de seu bebê. A relação enfermeiro-paciente tem grande influência na recuperação do RN (SOUZA et al., 2019; STELMAK et al., 2017).

Por meio da assistência humanizada, o enfermeiro também pode proporcionar mais conforto ao neonato de baixo peso, como ambiente com uma iluminação adequada e sem ruídos; uma boa posição na incubadora, que possa lhe trazer mais conforto e segurança; cuidado em todas as etapas, sempre observando como o bebê se comporta ao final de cada procedimento e, acima de tudo, na medida do possível, aumentar o vínculo afetivo entre RN e a família deste. Deve-se amenizar a dor da família mostrando-Ihe o RN antes de encaminhá-lo para a UTI, explicar o motivo de estar ligado a aparelhos e qual a função de cada um destes e envolver a família do RN nos cuidados básicos (STELMAK et al., 2019; BRASIL, 2017; GESTEIRA et al., 2016).

Pelo fato de o Método Canguru ser algo novo e um tipo de tratamento mais técnico, a equipe acaba enfrentando alguns problemas em relação à família do neonato, uma vez que esta pode sentir grande insegurança para a realização do método, como o medo de tocar no RN por ser ainda muito pequeno, ou o medo de realizar alguma etapa errada e prejudicar a sua saúde, que já está instável. Dessa forma, cabe ao enfermeiro e à sua equipe estar sempre presentes durante os procedimentos, auxiliando os familiares do RN mais atentamente no que for preciso (RODRIGUES et al., 2019).

Além dessas situações, destaca-se a questão da participação do pai do RN na aplicação do método, já que ele também tem grande influência no tratamento. As barreiras, como a dificuldade que os pais normalmente têm de segurar um RN, precisam ser rompidas e estes devem ser incluídos nesse momento, que é importante para a criação de vínculo entre eles (MANTELLI et al., 2017).

A equipe deve demonstrar solidariedade nesse momento, oferecer um cuidado humanizado, proteger e acolher essa família, ajudá-la a lidar com a dor e o sofrimento. Por meio de educação em saúde, deve deixar o mais claro possível todo o processo de cuidar. Cabe ainda à equipe, de um modo geral, orientar a família do RN quanto a medidas de proteção à criança, cuidados gerais e banho de sol. 0 enfermeiro deve dar todas as informações possíveis de forma individual, apoiando a família e a mãe do RN (PESSOA et al., 2016). 


\section{CONSIDERAÇÕES FINAIS}

Os benefícios do MC incluem: a estabilização fisiológica, como a frequência cardíaca; a diminuição da dor e do choro da criança; auxílio no ganho de peso e na busca pela amamentação e sucção; a formação de um vínculo afetivo entre mãe e RN; maior participação do enfermeiro e sua equipe durante a terapêutica. Como desafios assumem maior importância o medo da mãe de tocar na criança, às vezes pelo fato de esta estar ligada a aparelhos e a baixa adesão do pai à terapêutica, fato que deve ser influenciado e incluso ao Método Canguru.

Um dos fatores limitantes desta investigação envolve o delineamento metodológico, do tipo revisão integrativa. Sugere-se a realização de novas pesquisas de campo a respeito da temática em busca de mais evidências científicas que contribuam para a conscientização dos profissionais que atuam nos cuidados intensivos ao RN, visando à abordagem e a utilização clínica do MC. 


\section{REFERÊNCIAS}

ALCÂNTARA, DC et al. Cateter central de inserção periférica: contribuições para a enfermagem oncológica. Rev enferm UFPE on line., Recife, v.13, n. 3, p.715-31, mar., 2019. Disponível em: https://periodicos.ufpe.br/revistas/revistaenfermagem/article/view/236058/31568. Acesso em: 10 out. 2019.

BRASIL. Ministério da Saúde. Secretaria de Ciência, Tecnologia e Insumos Estratégicos. Departamento de Ciência e Tecnologia. Agenda de prioridades de pesquisa do Ministério da Saúde - APPMS. Brasília, 2018. Disponível em:

http://bvsms.saude.gov.br/bvs/publicacoes/agenda_prioridades_pesquisa_ms.pdf. Acesso em: 10 out. 2019.

BRASIL a. Agência Nacional de Vigilância Sanitária (ANVISA). Medidas de Prevenção de Infecção Relacionada à Assistência à Saúde. Brasília; ANVISA, 2017. Disponível em: https://www20.anvisa.gov.br/segurancadopaciente/index.php/publicacoes/item/caderno-5. Acesso em: 20 set. 2019.

BRASIL b. [Parecer COFEN no 243/2017]. Minuta de Resolução que atualiza a normatização do procedimento de inserção, fixação, manutenção e retirada de cateter periférico central por enfermeiro - PICC. (2017). Disponível em: http://www.cofen.gov.br/parecer-de-relator-cofen-no2432017_57604.html. Acesso em: 22 set. 2019.

BRASIL. [Lei № 7.498/86, de 25 de Junho de 1986]. Dispõe sobre a regulamentação do exercício da Enfermagem e dá outras providências (1986). Disponível em: http://www.cofen.gov.br/lei-n-749886de-25-de-junho-de-1986_4161.html. Acesso em: 20 set. 2019.

BRASIL. Ministério da Saúde. Secretaria de Atenção à Saúde. Departamento de Ações Programáticas Estratégicas. Atenção humanizada ao recém-nascido: Método

Canguru: manual técnico / Ministério da Saúde, Secretaria de Atenção à Saúde, Departamento de Ações Programáticas Estratégicas. - 3. ed. - Brasília : Ministérioda Saúde, 2017. 340 p. Disponível em:

http://bvsms.saude.gov.br/bvs/publicacoes/atencao_humanizada_metodo_canguru_manual_3ed.p df. Acesso em: 18 set. 2019.

BRASIL. Instituto de Saúde. Método Canguru no Brasil: 15 anos de política pública /organizado por Maria Teresa Cera Sanches. [et al]. São Paulo: Instituto de Saúde,2015. 261p. (Temas em saúde coletiva, 19). Disponível em

http://www.saude.sp.gov.br/resources/instituto-de-saude/homepage/temas-saude coletiva/pdfs/canguru_capa_miolo.pdf. Acesso em: 16 set. 2019.

FARIAS et al. Posição canguru em recém-nascidos pré-termo de muito baixo peso: estudo descritivo. Rev. Eletrônica enferm; 19: 1-10, 20170000. Disponível em:

http://docs.bvsalud.org/biblioref/2017/06/836934/a15.pdf. Acesso em: 11 out. 2019. 
GESTEIRA et al. Método canguru: benefícios e desafios experienciados por profissionais de saúde. Rev. enferm. UFSM; 6(4): 518-528, out.-dez. 2016. Disponível em:

https://periodicos.ufsm.br/reufsm/article/view/20524/pdf.Acesso em: 11 out. 2019.

MANTELLI et al. Método canguru: percepções da equipe de enfermagem em terapia intensiva neonatal. Rev. Enfer UFSM, Porto Alegre, v.7 n.1, p. 51-60, Jan/Fev. 2017. Disponível em: https://periodicos.ufsm.br/reufsm/article/view/21182. Acesso em: 02 nov 2019.

RODRIGUES et al. Cuidado centrado na família e sua prática na unidade de terapia intensiva neonatal. Rev Rene (Online); 20(1): e39767, jan. -dez. 2019. Disponível

em:http://periodicos.ufc.br/rene/article/view/39767/pdf. Acesso em: 11 out. 2019.

SOUSA et al. Fortalecimento do vínculo entre a família e o neonato prematuro, Rev.enferm. UFPE online13(2): 298-306, Fev. 2019. Disponível em:

https://pesquisa.bvsalud.org/brasil/resource/pt/biblio-1009888. Acesso em: 11 out. 2019.

STELMAK et al. O valor atribuído pelos profissionais de enfermagem aos cuidados preconizados pelo método canguru, Rev. Enferm. UFPE online; 11(9): 3376-3385, set.2017. Disponível em: https://pesquisa.bvsalud.org/brasil/resource/pt/bde-32924. Acesso em: 11 out. 2019.

ZIRPOLI et al. Benefícios do Método Canguru: uma revisão integrativa, Rev. Pesqui. Cuid. Fundam. (online); 11(2, n.esp): 547-554, jan. 2019. Disponível em:

http://www.seer.unirio.br/index.php/cuidadofundamental/article/view/6541/pdf. Acesso em: 11 out. 2019. 


\section{Capítulo 3}

\section{doi $10.37423 / 210804679$}

\section{CUIDADOS DE ENFERMAGEM NO CATETERISMO VENOSO PERIFÉRICO PEDIÁTRICO}

Geisa Aisla Sandi Rodrigues Pereira

Paula Krempser

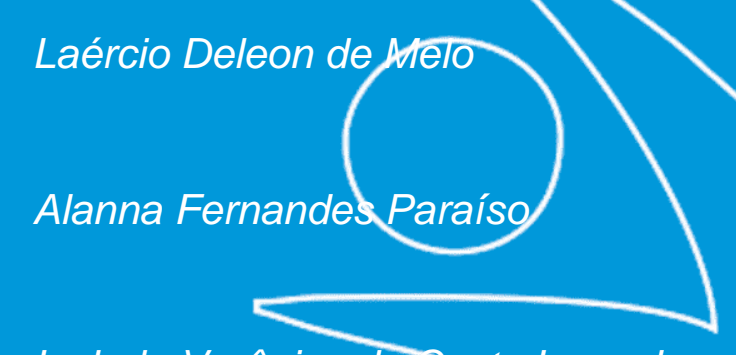

Isabela Verônica da Costa Lacerda

Giulia Alvim Bassani Silvé

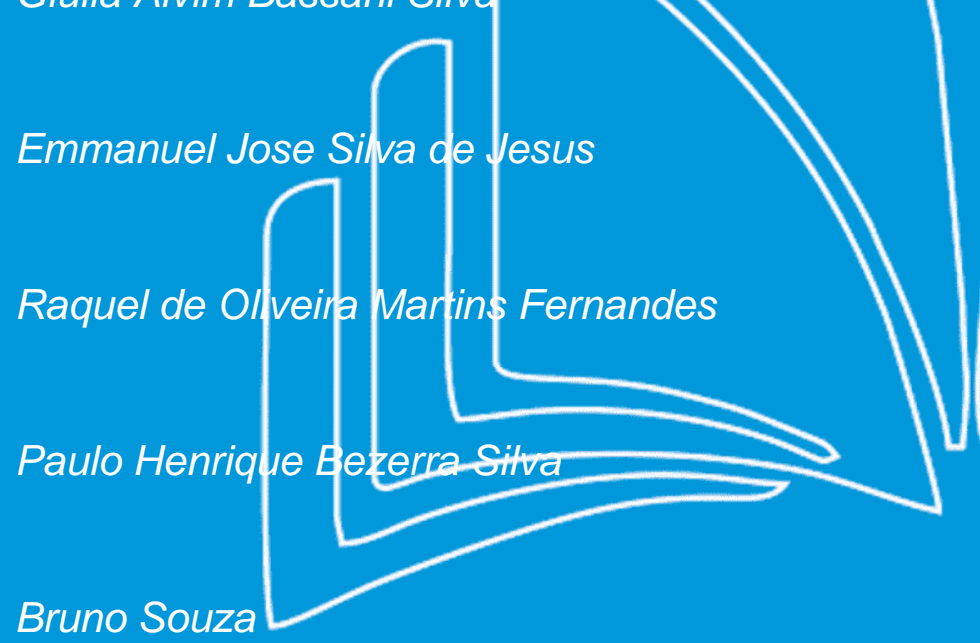

Centro Universitário Estácio de Juiz de Fora

Universidade Federal de Juiz de Fora

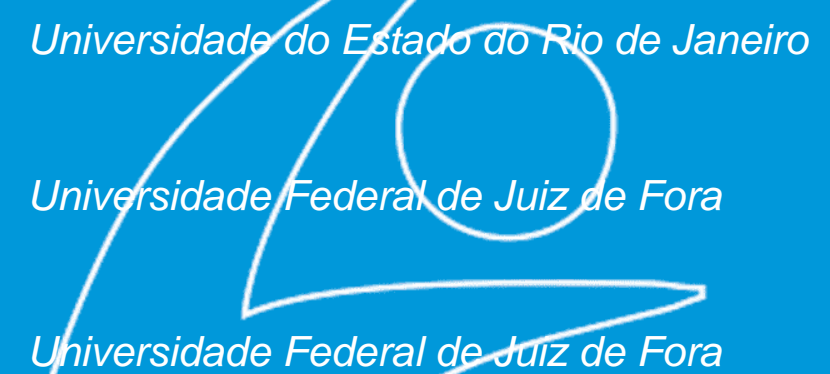

Universidade Federal de Juiz de Fora

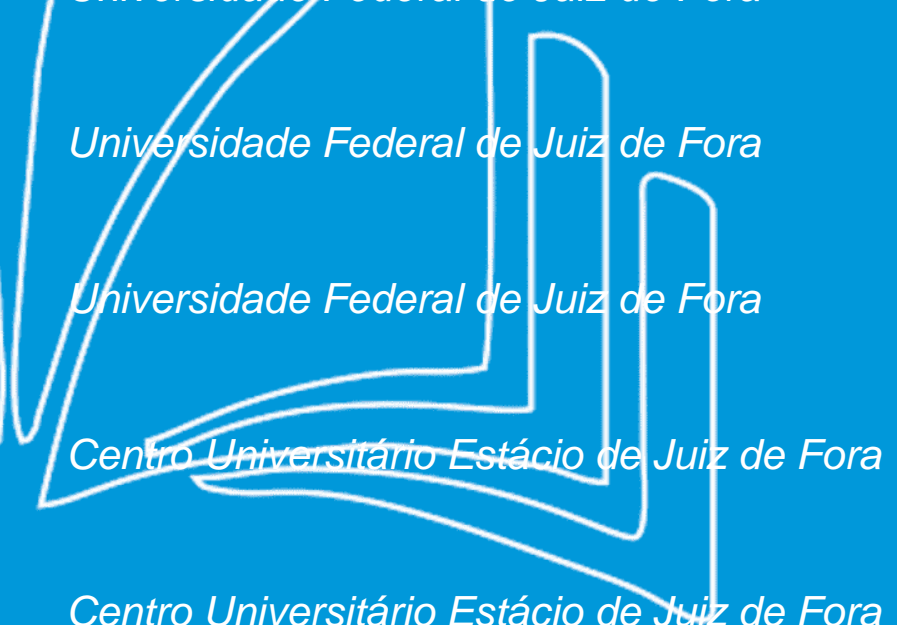


Resumo: O processo de punção venosa periférica é uma técnica utilizada desde a Segunda Guerra Mundial e tornou-se procedimento de escolha na hospitalização de crianças para viabilizar terapias medicamentosas. Apesar de benéfico, o cateterismo periférico em crianças pode causar traumas vasculares, desconfortos emocionais e físicos e impactar de forma traumática o seu desenvolvimento, configurando a importância da assistência qualificada da enfermagem. Os objetivos da presente investigação foram identificar os cuidados de enfermagem direcionados ao cateterismo venoso periférico pediátrico, avaliar a necessidade de qualificação da equipe de enfermagem e as dificuldades enfrentadas por esta. Trata-se de pesquisa do tipo revisão de literatura. Foram realizadas buscas nas bases de dados eletrônicas Lilacs, Bdenf e SciELO, a partir dos portais BVS e Capes, utilizando os descritores: Enfermagem; Pediatria; Cateterismo Periférico; Segurança do Paciente e Infusões Intravenosas em combinações, no período de 2009 a 2021, resultando, após leitura e aplicação dos critérios de inclusão e exclusão, em 15 publicações. Foram identificados cuidados de enfermagem direcionados ao cateterismo venoso periférico pediátrico que são capazes de diminuir a dor, o número de punções e a perda de acesso; aumentar o entendimento e a aceitação do procedimento pela criança e, consequentemente, diminuir o seu sofrimento. Ressalta-se a necessidade de qualificação e capacitação dos profissionais de enfermagem para o uso dessas tecnologias. O enfermeiro e a família são imprescindíveis para a realização de um cuidado humanizado e voltado para prevenção de agravos à criança submetida a punção venosa.

Palavras-Chaves: Enfermagem. Pediatria. Cateterismo Periférico. Segurança do Paciente. Infusões Intravenosas. 


\section{INTRODUÇÃO}

Após a descoberta do funcionamento da circulação sanguínea corpórea por William Harvey, começaram as especulações acerca da forma como essa circulação poderia auxiliar no tratamento de doenças. Foi então que Christopher Wren inventou um dispositivo capaz de chegar até a hipoderme e realizar as primeiras punções. Inicialmente foi utilizado material inferior para construir o dispositivo, que foi aprimorado, passando de aço inoxidável para material flexível e descartável (DOMINGUES; MORAES; JÚNIOR, 2012).

A técnica começou a ser aplicada durante a segunda Guerra Mundial por médicos que utilizavam as punções como uma das formas auxiliares no tratamento de feridos, mas, com a grande demanda e poucos profissionais, a enfermagem começou a desempenhar a técnica, tornando-se um dos procedimentos mais realizados pela equipe de enfermagem (PHILLIPS, 2014).

A punção venosa periférica é um dos procedimentos mais utilizados na hospitalização de crianças para a infusão de fármacos e hemoderivados. Tal escolha é feita pelo fato de conseguir infundir uma quantidade de volume maior e também por proporcionar a ação medicamentosa quase que imediatamente, trazendo à criança uma melhora de seu quadro clínico (MELO et al., 2015).

A punção venosa periférica é um procedimento invasivo que causa complicações como os traumas vasculares e desconfortos emocionais e físicos em crianças no processo de hospitalização, podendo impactá-las de forma traumática a ponto de interferir em seu crescimento e desenvolvimento. Pode interferir no mundo lúdico, colocando em evidência o momento de sofrimento, de dor, de aflição, e gerar, entre outras complicações, retração social e fobias (CUNHA; SILVA, 2012; MELO et al. , 2015; KREMPSER, 2014).

Para que o processo de punção venosa nas crianças seja menos traumático, o enfermeiro desempenha um papel fundamental, desde o conhecimento técnico- científico até os cuidados pós-remoção do cateter (MELO et al., 2015). Dessa forma, o profissional de enfermagem habilitado a realizar a técnica deve explicar o procedimento que irá desempenhar para que o seu tratamento seja realizado com sucesso e sem complicações, atentando para a comunicação não verbal, pois, nessa fase da vida, a criança não consegue expor de forma clara seus sentimentos (CUNHA; SILVA, 2012).

Estima-se que uma taxa significativa de $1 \%$ a $10 \%$ das hospitalizações cause dano ao paciente, sendo sistêmico ou local, decorrente de alguma alteração na pele durante o processo de inserção do cateter 
venoso periférico. No entanto um cuidado pautado em evidências científicas pode evitar que isso aconteça (MACHADO; PEDREIRA; CHAUD, 2008).

O procedimento de cateterismo venoso periférico é uma atribuição da equipe de enfermagem no cotidiano de sua assistência, caracterizando-se como um procedimento invasivo que necessita de planejamento, sistematização das ações, conhecimentos e atualização (MELO et al., 2015).

O enfermeiro é o profissional que está habilitado a exercer funções de gestão e administração de cuidados de enfermagem e também atua junto com sua equipe. Cabe a ele realizar escolhas adequadas e capacitar sua equipe, objetivando segurança e conforto às crianças durante o processo de cateterismo venoso periférico, uma técnica relativamente simples, mas que pode trazer maiores danos à criança hospitalizada caso o profissional não atente aos passos do procedimento e aos cuidados a serem tomados (MELO et al., 2015).

A presente investigação se justifica por: 1) ser o cateterismo periférico essencial para o estabelecimento da terapia medicamentosa em crianças, caracterizado como a via de escolha de tratamento pediátrico pela eficiência e eficácia de tratamento nesse público, 2) existir especificidade de cuidados de enfermagem que devem ser realizados nesse público devido ao perfil de agitação, instabilidade emocional e dificuldade de aceitação dos cuidados de enfermagem e 3) ser o público infantil caracterizado por necessitar de um familiar como cuidador em tempo integral durante a hospitalização.

Diante do exposto, o objeto desta pesquisa são os cuidados de enfermagem direcionados ao cateterismo venoso periférico pediátrico. Os objetivos da pesquisa foram identificar os cuidados de enfermagem direcionados ao cateterismo venoso periférico pediátrico, avaliar a necessidade de qualificação da equipe de enfermagem e as dificuldades enfrentadas por essa equipe referentes ao cateterismo venoso pediátrico.

\section{METODOLOGIA}

Pesquisa qualitativa do tipo revisão de literatura que objetivou demonstrar o panorama atual das pesquisas que abordam a temática relacionada ao objeto de pesquisa e discutir sobre os cuidados de enfermagem direcionados ao cateterismo venoso periférico pediátrico.

A revisão da literatura foi realizada nos meses de março a maio de 2019 e atualizada em agosto de 2021, com uma pesquisa no portal da Biblioteca Virtual em Saúde - BVS e no portal da Coordenação de Aperfeiçoamento de Pessoal de Nível Superior (Capes) e nas bases de dados Literatura Latino 
Americana em Ciências de Saúde (Lilacs), Banco de Dados Bibliográficos Especializado na Área de Enfermagem do Brasil (Bdenf), National Library of Medicine (Medline) e Scientific Electronic Library Online (SciELO), no período de 2009 a 2021.

Para seleção dos estudos, utilizaram-se os seguintes critérios de inclusão: artigos completos em português, inglês e espanhol; dissertações e teses de abordagem qualitativa e que estivessem disponíveis eletronicamente nas bases de dados. Foram critérios de exclusão: as publicações repetidas nas bases pesquisadas, as produções do tipo estudo de caso, artigos de reflexão e de revisão, livros e capítulos de livros e publicações que apresentassem falta de aderência ao tema investigado.

Para a realização da busca, foram utilizados os descritores: "Enfermagem"; Pediatria"; "Cateterismo Periférico"; "Segurança do Paciente" e "Infusões Intravenosas" em combinações. Após, foi realizada uma leitura analítica com a finalidade de categorizar as informações contidas nas fontes, de forma que essas possibilitassem a obtenção de respostas ao problema da pesquisa.

Ao combinar os descritores nas bases de dados pesquisadas, foram encontradas no total 15 publicações, tendo sido, no portal BVS, identificados na base de dados Medline cinco artigos; na Lilacs, foram encontrados três artigos e, na Bdenf, foram encontrados dois artigos. No portal da Capes, na base de dados SciELO, foram cinco artigos.

\section{RESULTADOS E DISCUSSÕES}

As categorias que emergiram da etapa anterior foram analisadas e discutidas a partir do referencial temático do estudo e são apresentadas a seguir.

\subsection{OS CUIDADOS DE ENFERMAGEM DIRECIONADOS AO CATETERISMO VENOSO PERIFÉRICO PEDIÁTRICO}

A anamnese é o primeiro passo para que se obtenha uma história prévia da criança, de forma a identificar seus históricos de internação; experiências e vivências, relatos de eventos adversos como flebites e infiltrações, múltiplas tentativas de punção venosa; oportunidade de entrevistar a família e/ou responsável e a própria criança e oportunidade de estabelecer vínculos e confiança com a criança para procedimentos dolorosos, mas necessários (NEGRI et al., 2012).

Estudo indica que técnicas devem ser utilizadas para diminuir o sofrimento da criança antes da punção venosa como o uso de anestésico local como a Lidocaína Lipossomal $4 \%$ de 30 a 60 minutos antes da 
punção, como forma de reduzir a dor, aumentar o conforto da criança e assim contribuir para o sucesso na punção venosa periférica (SKARBECK-BOROWSKA, 2006).

Outra técnica muito significativa que vem sendo utilizada durante a hospitalização da criança é a utilização de brinquedos terapêuticos, que auxilia o enfermeiro a se aproximar da criança e formar um vínculo, criando empatia e gerando confiança na explicação do procedimento terapêutico a que a criança irá ser submetida, sendo utilizado quando a equipe de enfermagem enfrenta dificuldade em se comunicar com a criança. Eles possuem a finalidade de aliviar a ansiedade da criança que está passando por um momento atípico para sua idade, o qual está ameaçando seu mundo lúdico; auxiliar na compreensão da sua nova experiência; desestressar a criança até o conhecimento de seu tratamento e desmitificar conceitos errôneos preestabelecidos (BARROSO et al., 2020).

A escala Difficult Intravenous Access Score (DIVA score) é mais uma tecnologia que vem para aprimorar os conhecimentos da enfermagem e tornar a punção venosa periférica menos dolorosa para a criança, com ela é possível avaliar o grau de dificuldade da punção e diminuir o seu insucesso. Ela se apresenta em uma escala, em que cada item tem sua pontuação (visibilidade, palpabilidade, idade, prematuridade, tom de pele) e, de acordo com a pontuação, avalia-se o grau de dificuldade da punção na primeira tentativa (MULLER, 2015).

O primeiro passo para se obter uma maior efetividade no processo de punção é a escolha correta do local de inserção para que o acesso tenha durabilidade. A primeira opção de escolha para puncionar são os membros superiores, evitando proximidade do membro, mão dominante e, se possível, fora das articulações. A segunda opção, que se destina a Recém-Nascidos (RNs), são as veias do couro cabeludo, pois apresentam acesso fácil e comodidade ao RN e aos lactantes, e a veia dos pés, que são a opção para a criança que não engatinha, dando-Ihe mais conforto a ela (MALYON, 2014).

A escolha correta proporciona mais eficácia à terapêutica, pois a criança continua com suas movimentações habituais e diminuem as limitações dela durante a hospitalização. É necessário escolher veias mais calibrosas porque trazem mais conforto às crianças e calibre do cateter adequado ao tipo de medicação que será infundida, e se devem evitar locais como a fossa antecubital, que dificulta a mobilidade (DOMINGUES; MORAES; JUNIOR, 2012).

Regiões com hematomas preexistentes devido a infiltrações de acessos passados apresentam um grau de dificuldade maior para realizar a punção, sendo necessário o garroteamento de membros que deve ser distalmente do local da punção, a fim de evitar uma pressão maior na parede do vaso e causar um extravasamento no ato da punção (NEGRI et al., 2012). 
A manutenção do cateter é influenciada por escolhas adequadas como o calibre do dispositivo, uso de curativo estéril, transparente e impermeável, salinização ou heparinização, realização de flushing, higienização do local de inserção. Considerando que as crianças são pacientes que apresentam difícil acesso e uma maior chance de desenvolver traumas e de perda acidental do acesso, tais ações aumentam o tempo de permanência e o funcionamento do cateter, evitando que complicações apareçam (NEGRI et al., 2012).

Ainda na manutenção, a observação diária do acesso é primordial, possibilitando identificar precocemente os sinais e sintomas de flebite e evitar a hiperplasia luminal, que é a diminuição do lúmen da veia e do fluxo sanguíneo, que gera o surgimento de eritema e de dor no local da punção (ALVES et al., 2019).

Na pediatria, não existe um tempo predeterminado para a retirada do cateterismo venoso periférico. Para que essa ação aconteça, será necessário que haja o cumprimento dos seguintes itens: avaliação rotineira da equipe de enfermagem, inspeção do local de inserção, avaliação da integridade da pele, curativo adequado, tipo de terapia medicamentosa, condição clínica do paciente, local de atendimento, integridade e permeabilidade do dispositivo, minimizando, assim, complicações como flebites, hematomas ou até mesmo infecção sanguínea mais grave que pode colocar em risco a vida da criança (ALMEIDA et al., 2016).

\subsection{A QUALIFICAÇÃO DA EQUIPE DE ENFERMAGEM PARA ATUAR NO CATETERISMO PERIFÉRICO PEDIÁTRICO}

A educação continuada para equipe de enfermagem é de suma importância para atualizar e avaliar suas técnicas, melhorando seu atendimento assistencial, para assim evitar futuras complicações durante a inserção do acesso venoso periférico. Disponibilizar mais conhecimento a toda equipe deve ser uma prática contínua, com abordagem em grupo, uso de métodos on-line e apresentação de práticas evidentes de inserção e manutenção do cateter (ALVES et al., 2019).

A utilização de tecnologias favorece bastante o trabalho da enfermagem. O uso do ultrassom de baixa frequência vem contribuindo muito durante a inserção do cateter, mostrando o trajeto da veia e o fluxo sanguíneo, mas, para que obtenha sucesso, o profissional necessita capacitação institucional para manusear o aparelho (SKARBECK-BOROWSKA, 2006).

Os enfermeiros precisam ter capacitação sobre a fixação do cateter venoso periférico, pois novas tecnologias já surgiram e eles têm que se aprimorar para prestar um cuidado adequado à criança. $A$ 
utilização de gazes e fitas adesivas para fixar o acesso já está ultrapassada, hoje estudos mostram que 71\% das flebites estão relacionados a fixações errôneas, por isso a utilização de oclusão do acesso venoso periférico por material transparente e estéril permite observar e detectar precocemente sinais de complicações (ALVES et al., 2019).

A obstrução do cateter ocorre em $2 \%$ a $22 \%$ dos pacientes hospitalizados independentemente da idade.Tal obstrução vem mostrar que alguma alteração clínica está acontecendo como o funcionamento inadequado do cateter. Estudo relata a importância do flushing como assistência e qualificação de enfermagem, mantendo sempre a via pérvia para assegurar um cateter funcionante sem a necessidade de sua remoção (BRAGA et al., 2017).

Outra qualificação necessária à equipe de enfermagem é a identificação de casos de flebite, por representar uma causa muito comum durante a hospitalização da criança, sendo necessário se ter conhecimento sobre os sinais e sintomas para identificar precocemente e intervir terapeuticamente. Segundo Jacinto et al. (2014), a flebite é classificada em três tipos: 1) Infecciosa: quando há contaminação da solução que está sendo infundida, do dispositivo e do local de inserção do cateter; 2) Mecânica: quando o dispositivo entra em contato com a parede do vaso causando um trauma na veia e 3) Química: quando a solução ou medicamento entram em contato com o exterior do vaso, atingindo a epiderme. Os sinais e sintomas da flebite são edema, calor no local, hiperemia, cordão fibroso no trajeto da veia e saída de exsudato no local da inserção do dispositivo.

Conhecer e divulgar os protocolos institucionais, mantê-los atualizados e revisados e ofertar educação continuada da equipe faz parte do processo do cuidado, de forma a capacitar os profissionais a desenvolver suas funções orientados a realizar a técnica correta, pautados em evidências científicas atualizadas (ALVES et al., 2019).

\subsection{AS DIFICULDADES ENFRENTADAS PELA EQUIPE DE ENFERMAGEM NO CATETERISMO VENOSO PEDIÁTRICO}

A inserção do cateter venoso periférico em criança é dificultada devido a anatomia, fisiologia e cognição próprias de cada etapa da infância. Somados a esses fatores, são identificados riscos que aumentam a chance de ter insucesso na punção venosa periférico como uso prévio de cateter central de inserção periférica e cateter venoso central, estado de desnutrição, histórico clínico de dificuldade na punção venosa periférica e complicações do tratamento intravenoso, como infiltração e extravasamento (NEGRI et al., 2012). 
Uma pesquisa realizada em um hospital público no estado de São Paulo, com cerca de 134 crianças hospitalizadas, sobre os fatores relacionados à retirada do cateter venoso periférico em crianças evidenciou que o motivo da retirada dos 134 CVPs foi dividido em 44,03\% para retiradas não planejadas, distribuídas em 16,42\% de infiltrações ou extravasamentos, 11,94\% flebites, 3,73\% obstruções, $8,21 \%$ retiradas acidentais e 3,73\% retiradas por causas não específicas, inclusive o uso de anti-infecciosos $(O R=7,03 ; p=0,0001)$. Punções venosas em membros inferiores $(O R=5,12 ; p=0,0070)$, punções anteriores $(O R=3,24 ; p=0,0014)$ e sexo masculino $(O R=2,70 ; p=0,0092)$ aumentaram o risco de retirada dos CVPs por causas não planejadas, os outros 55,97\% foram por retiradas planejadas, como término da terapia intravenosa, altas hospitalares ou transferências da pediatria (SILVA et al., 2020).

A agitação psicomotora da criança durante a punção venosa, sua manutenção e retirada é causada pela falta de conhecimento sobre a necessidade e importância do acesso venoso, as consequências da submissão a um procedimento doloroso, bem como pelo medo ao ver o sofrimento das demais crianças submetidas à punção venosa. Este se configura como mais um fator dificultador de sucesso no procedimento executado pelos profissionais de enfermagem. Para que seja possível realizar a cateterização venosa, pode ser necessário imobilizar a criança (FERREIRA et al., 2012; KREMPSER et al., 2020).

A escolha do local adequado para inserção do dispositivo e sua correta fixação devem ser bem avaliadas, pois a opção certa pelo local de inserção do cateter otimiza muito o serviço de enfermagem de forma a não restringir os movimentos da criança, diminuir o risco de perda acidental do cateter e a necessidade de nova punção (MALYON, 2014).

Além desses fatores estressores interpessoais sentidos pelos profissionais de enfermagem também desafiam o sucesso do procedimento alguns como dificuldades de acesso, agitação da criança e identificação da presença de dor na criança. Estas são causas que, direta ou indiretamente, podem impactar a realização da inserção do catéter (KREMPSER et al., 2020).

A presença da família no período de internação da criança é muito importante e eficaz, mas pode ser um estressor interpessoal, visto que os acompanhantes podem ter uma reação negativa ou não permitir a realização de vários procedimentos, uma vez que os familiares não estão acostumados com as rotinas e normas hospitalares e isso lhes gera sofrimento e medo. Por isso, é necessário que a equipe de enfermagem desenvolva relações interpessoais e cabe ao enfermeiro explicar as normas e rotinas para proporcionar o maior conforto para a criança e flexibilizar regras de forma a manter a 
harmonia da equipe com a família. Isso faz com que a criança tenha um tratamento terapêutico eficaz e satisfatório, diminuindo a perda de acessos precocemente, evitando a agitação da criança e futuras complicações que possam surgir (KREMPSER et al., 2020; XAVIER; GOMES; SALVADOR, 2014).

A interação entre a família da criança e o profissional de enfermagem deve ser construída desde o primeiro contato até a alta hospitalar da criança, pois esse passo se torna importante para proporcionar à criança uma segurança no decorrer de sua internação e nos possíveis procedimentos a serem realizados durante esse período. Esse contato também se torna útil para que o familiar obtenha informações sobre o caso clínico da criança, sobres seus direitos e deveres durante a hospitalização, assim como as normas e rotinas institucionais (XAVIER; GOMES; SALVADOR, 2014).

A participação familiar serve como um pilar para unir a criança e o enfermeiro, criando um vínculo de confiança que facilita o desempenho das atividades profissionais, além de gerar responsabilidades mútuas, o familiar como intermediador e o profissional como supervisor e gerenciador de cuidados, identificando as dificuldades (MELO et al., 2015).

\section{CONSIDERAÇÕES FINAIS}

Ao analisar os cuidados de enfermagem prestados à criança submetida ao cateterismo venoso periférico, verificou-se que eles devem ocorrer em todo o processo e que as ações da equipe de enfermagem são capazes de diminuir a dor, o estresse, o número de punções e a perda de acesso, além de aumentar o entendimento e a aceitação do procedimento pela criança e consequentemente diminuir seu sofrimento.

Cuidados são necessários de forma a diminuir as dificuldades para estabelecer, manter e retirar acessos venosos em criança. Entre as dificuldades relacionadas à criança estão estresse emocional, mudanças de hábitos de seu quotidiano, negação, perda de seu mundo lúdico, a presença da família, a agitação psicomotora, aspectos fisiológicos e anatômicos.

Para que a assistência de enfermagem direcionada ao acesso venoso periférico em crianças seja efetiva, é necessária a constante qualificação e capacitação dos profissionais de enfermagem para o uso das tecnologias existentes. Manter protocolos atualizados e disponíveis para a equipe torna o trabalho mais eficaz e sugestivo de sucesso, facilitando a aceitação do tratamento tanto pela criança quanto por sua família.

A presente investigação tem como limite a busca por estudos que abordassem os cuidados da enfermagem direcionados ao processo de punção venosa periférica, mostrando a necessidade de se 
conhecer na prática clínica como esses cuidados vêm sendo realizados para que atualizações sejam implementadas na assistência frente ao grande impacto que o procedimento gera, psicológica e fisicamente, na criança.

Sugere-se que novos estudos acerca do redimensionamento dos cuidados de enfermagem direcionados ao processo de punção venosa em crianças sejam realizados para contribuir na inclusão de novos ações que impactem a qualidade da assistência de enfermagem. 


\section{REFERÊNCIAS}

AMARAL, MCK do; PETTENGILL, MAM. Uso do ultrassom para guiar a punção venosa periférica em crianças: significado para a enfermeira. ACTA, São Paulo, 2010. Disponível em: www.scielo.br/pdf/ape/v23n4/05.pdf. Acesso em: 23 maio 2019.

ANVISA; BRASIL. Medidas de Prevenção de Infecção Relacionada à Assistência à Saúde. Brasília: Copyright @) 2017. Disponível em: portal.anvisa.gov.br/...4...à.../a3f23dfb-2c54-4e64-881cfccf9220c373. Acesso em: 7 maio 2019.

ALMEIDA, TJC de. et al. Acessos venosos periféricos em crianças hospitalizadas: um estudo fotográfico. Rev enferm UFPE on line., Recife, V. 10, (Supl. 2), p. 701-7, fev., 2016. Disponível em: https://periodicos.ufpe.br/revistas/revistaenfermagem/article/viewFile/11009/12379. Acesso em: 18 de maio de 2019.

ALVES, DA. et al. Avaliação das condutas de punção e manutenção do cateter intravenoso periférico. RECOM, São João Del Rei, 2019. Disponível em:

http://www.seer.ufsj.edu.br/index.php/recom/article/view/3005. Acesso em: 18 maio 2019.

ALVES, DA. et al. Cateter Intravenoso Periférico: Características Físicas do Sítio de Inserção e Conhecimento da Equipe de Enfermagem. 2019;9: e3005. Disponível em:

http://seer.ufsj.edu.br/index.php/recom/article/view/3005/2081. Acesso em: 25 mar. 2019. DOI: http://dx.doi.org/10.19175/recom.v9i0.3005

BARROSO, MCCS et al. Percepção das crianças acerca da punção venosa por meio do brinquedo terapêutico. Acta Paulista de Enfermagem, v. 33, 2020. Disponível em: https://www.scielo.br/j/ape/a/YkWGF8SkcBkF73467PQYcZq/?format=pdf\&lang=pt. Acesso em: 08 de agosto de 2021.

BATALHA, LMC et al. Fixação de cateteres venosos periféricos em crianças: estudo comparativo. Escola Anna Nery, Rio de Janeiro, jul/set 2010. Disponível em: http://www.scielo.br/scielo.php?pid=S1414$81452010000300012 \&$ script=sci_abstract\&tlng=pt. Acesso em: 16 maio 2019.

BRAGA, LM et al. Taxa de incidência e o uso do flushing na prevenção das obstruções de cateter venoso periférico. Texto Contexto Enfermagem, Florianópolis, Nov 2018. Disponível em: http://www.scielo.br/pdf/tce/v27n4/0104-0707-tce-27-04-e2810017.pdf. Acesso em: 23 mar. 2019.

CUNHA, GL da; SILVA, LF da. Lúdico Como Recurso Para o Cuidado de Enfermagem Pediátrica na Punção Venosa. REVISTA da Rede de Enfermagem do Nordeste, Ceará, 2012. Disponível em: www.periodicos.ufc.br/rene/article/view/4098. Acesso em: 7 maio 2019.

DOMINGUES, G; MORAES, FRRL de; JÚNIOR, MAF. Tempo de permanência dos cateteres venosos periféricos e seus riscos para flebite relacionado ao sítio de inserção. Revista Científica Indexada Linkania Júnior, [S. I.], Abril/Jul 2012. Disponível em: linkania.org/junior/article/view/50. Acesso em: 26 mar. 2019.

FERREIRA, $M$ et al. Care of nursing team to children with peripheral venous puncture: descriptive study. Online Brazilian Journal of Nursing. v. 11, n. 1, April 2012. 
GOMES, GC; OLIVEIRA, PK de. Vivências da família no hospital durante a internação da criança. Rev Gaúcha Enferm., v. 33, n. 4, p. 165-171, Dec. 2012. Disponível em $<$ http://www.scielo.br/scielo.php?script=sci_arttext\&pid=S1983-14472012000400021. Acesso em: 06 Abril 2019. DOI: dx.doi.org/10.1590/S1983-14472012000400021

JACINTO, AKL et al. Flebite associada a cateteres intravenosos periféricos em crianças: estudo de fatores predisponentes. Esc. Anna Nery, Rio de Janeiro, 2014. Disponível em: www.scielo.br/scielo.php?pid=S1414-81452014000200220\&script=sci...tlng... Acesso em: 23 maio 2019.

KREMPSER, P. Trauma Vascular Periférico em Urgência: Impacto após implantação de Bundle [Dissertação de Mestrado]. Juiz de Fora: Universidade Federal de Juiz de Fora, 2014.

KREMPSER, P et al. Representações sociais e os estressores da punção venosa pediátrica: contribuições para o cuidado de enfermagem. Enfermagem em Foco, [S.I.], v. 11, n. 4, jan. 2021. ISSN 2357-707X. Disponível em: <http://revista.cofen.gov.br/index.php/enfermagem/article/view/3032>. Acesso em: 04 ago. 2021.

MACHADO, AF; PEDREIRA, MLG; CHAUD, MN.Eventos Adversos Relacionados ao Uso de Cateteres Intravenosos Periféricos em Criança de Acordo com Tipos de Curativos.. REVISTA LATINO AMERICANO EM ENFERMAGEM, SÃO PAULO, MAIO/JUNHO 2008. Disponível em:

www.scielo.br/pdf/rlae/v16n3/pt_05.pdf. Acesso em: 26 mar. 2019.

MALYON, L et al. Duração periférica intravenosa cateter e falha em cuidados intensivos pediátricos: Um estudo prospectivo. EMA, Austrália, 2014. Disponível em:

https://www.ncbi.nlm.nih.gov/pubmed/25346034. Acesso em: 18 maio 2019.

MELO, EM et al. Cuidados Dispensados pela Equipe de Enfermagem Durante o Procedimento de Punção Venosa Periférica. REVISTA DE ENFERMAGEM DA UFPE, RECIFE, 30 mar. 2015. Disponível em: https://periodicos.ufpe.br/revistas/revistaenfermagem/article/download/10430/11226. Acesso em: 26 mar. 2019. DOI: 10.5205/reuol.7505-65182-1-RV.0903201502

MÜLLER, PCS. Adaptação Transcultural e Validação Clínica do Difficult Intravenous Access score - DIVA score - para uso no Brasil. Programa de Pós Graduação em Enfermagem, Mestrado Profissional em Enfermagem - Universidade Federal do Paraná. Curitiba, PR, 2015.Disponível em :

https://acervodigital.ufpr.br/handle/1884/41871. Acesso em 26 maio 2019.

NEGRI, DC de et al. Fatores predisponentes para insucesso da punção intravenosa periférica em crianças. REVISTA LATINO-AMERICANA EM ENFERMAGEM, SÃO PAULO, Nov/Dez 2012. Disponível em: www.scielo.br/pdf/rlae/v20n6/pt_09.pdf. Acesso em: 26 mar. 2019.

PHILLIPS, LD; GORSKI, LA. Manual de IV Terapêutica: Prática Baseada em Evidências para Terapia por Infusão. Filadélfia: F.A. Davis Company by Copyright @) 2014. Disponível em: iranianfamilyphysicians.com/images/book/Lynn_D_Phillips_MSN_RN_CRNI,_.pdf. Acesso em: 26 mar. 2019. 
SKARBECK-BORAWSKA, SMD et al. Brief Focal Ultrasound With Topical Anesthetic Decreases the Pain of Intravenous Placement in Children. Pediatric Emergency Care, v.22, n. 5 , p 339-345, Mai 2006. Disponível em:

https://journals.Iww.com/peconline/Abstract/2006/05000/Brief_Focal_Ultrasound_With_Topical_A nesthetic.7.asp. Acesso em: 26 maio 2019.

XAVIER, DM; GOMES, GC.; SALVADOR, MS. O familiar cuidador durante a hospitalização da criança: convivendo com normas e rotinas. Escola Anna Nery, Rio de Janeiro, 2014. Disponível em: www.scielo.br/pdf/ean/v18n1/1414-8145-ean-18-01-0068.pdf. Acesso em: 23 maio 2019. 


\section{Capítulo 4}

\section{doi $10.37423 / 210804680$}

\section{PRÁTICAS DE EDUCAÇÃO EM SAÚDE DESENVOLVIDAS POR ENFERMEIROS SOBRE O ALEITAMENTO MATERNO EXCLUSIVO}

Ana Paula Pedro da Silva

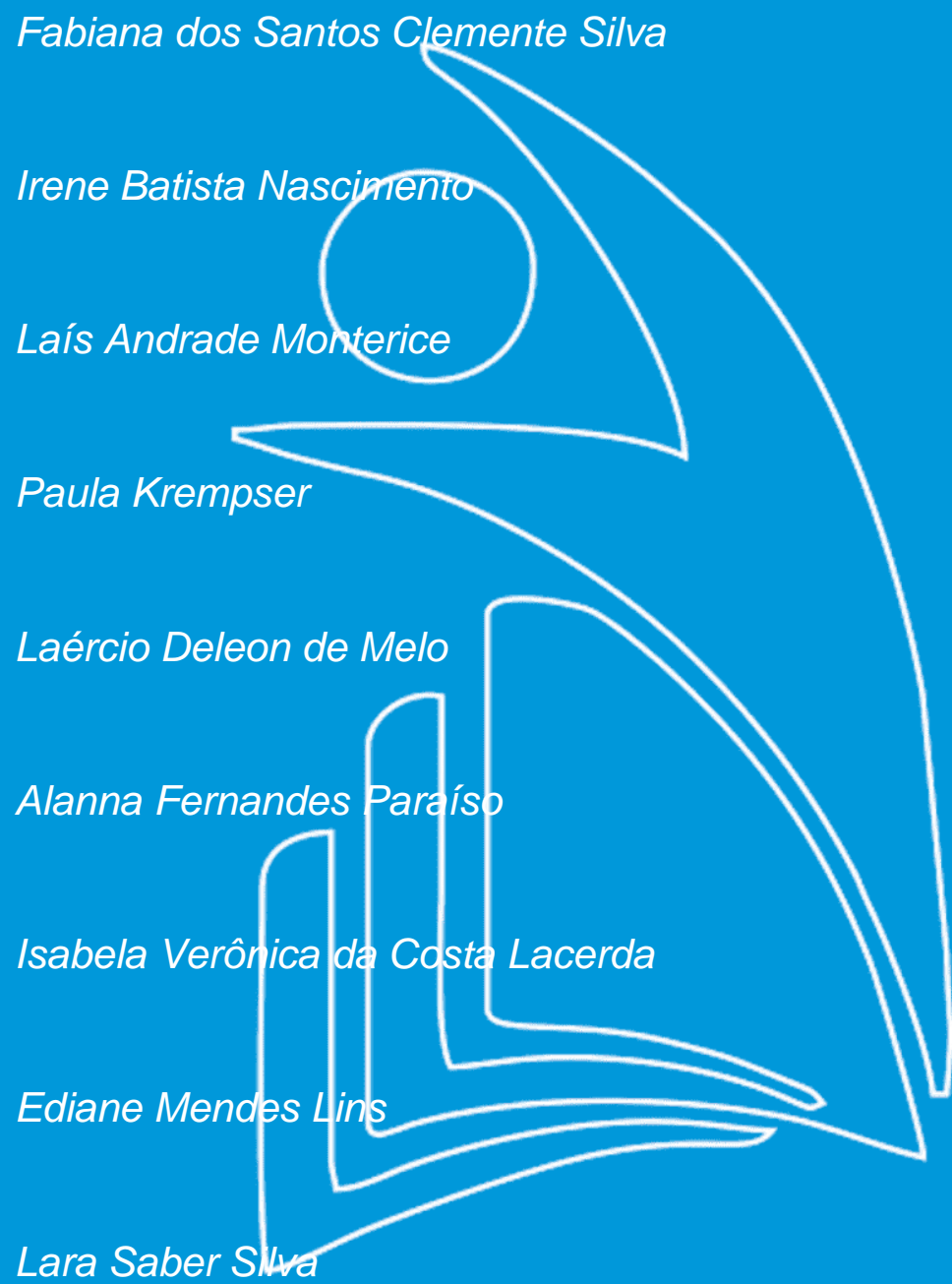

Centro Universitário Estácio de Juiz de Fora

Centro Universitário Estácjo de Juiz de Fora

Centro Univgrsitárjb Estaciode Juiz de Fora

Universidade a Estado do Rio de Janeiro

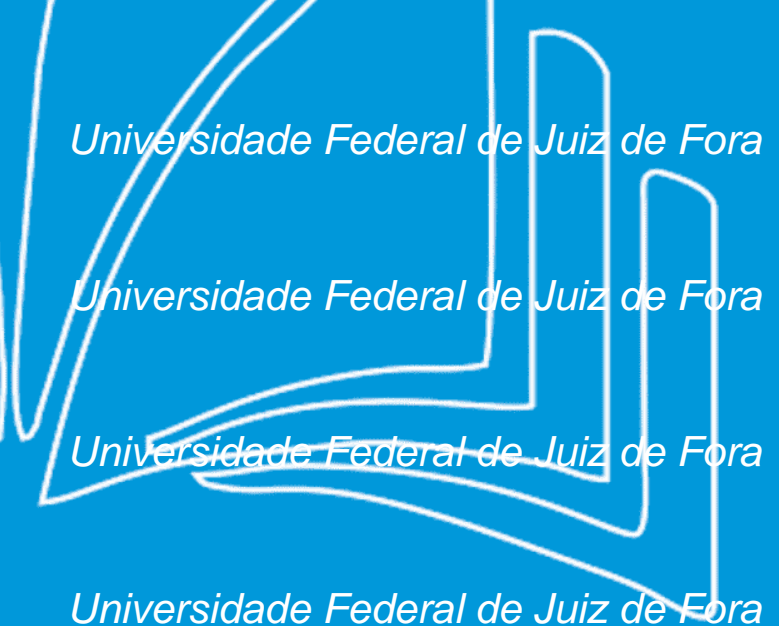




\section{Resumo:}

Introdução: o aleitamento materno exclusivo (AME) é benéfico tanto para a mãe quanto para o bebê, e o enfermeiro desempenha um papel importante por meio de práticas educativas. Objetivou-se descrever as ações de educação em saúde desenvolvidas por enfermeiros para aderência ao AME. Foi realizada uma pesquisa qualitativa do tipo revisão de literatura nos meses de agosto a outubro de 2019 e atualizada em agosto de 2021, nas bases de dados: BVS, portal da Capes, Lilacs, Bdenf e SciELO. Utilizaram-se como critérios de inclusão artigos completos em português, inglês e espanhol, disponíveis eletronicamente nas bases de dados no período de 2015 a 2021. Desenvolvimento: após aplicação dos critérios de inclusão e exclusão, foram incluídas 13 investigações, que possibilitaram a estruturação de duas categorias: a importância da educação em saúde no $A M E$, que abordou estratégias para promoção da qualidade dos cuidados realizados e atuação em serviço de forma segura e efetiva, proporcionando a aquisição de novos conhecimentos para que se atinja a capacidade profissional e o desenvolvimento pessoal de acordo com a realidade social e institucional; atuação do enfermeiro no AME, que envolve as ações assistenciais e educativas à lactante direcionadas a pega e sucção, correta da amamentação e apropriado posicionamento do bebê, esvaziamento adequado das mamas, importância dos intervalos das mamadas e AME, orientações sobre os fatores que contribuem para a descida do leite, uso do próprio leite como cicatrizante do mamilo fissurado. Considerações finais: as práticas de educação em saúde desenvolvidas por enfermeiros para a aderência ao AME são estratégias importantes de promoção de saúde e geradoras de mudança de comportamentos. Portanto é fundamental que o enfermeiro conheça e forneça informações acerca da importância da amamentação e seus benefícios para o binômio mãe-bebê.

Palavras-chaves: Educação em Saúde. Enfermagem Materno-Infantil. Aleitamentoto Materno. Enfermagem em Saúde Pública. Promoção da Saúde. 


\section{INTRODUÇÃO}

A amamentação é uma prática natural e adequada para a nutrição do recém-nascido, principalmente durante os seis primeiros meses de vida. Proporciona benefícios que atuam na condição alimentar, estimulando o crescimento e desenvolvimento adequado da criança, reduzindo os índices de morbimortalidade infantil, além de favorecer o vínculo afetivo entre mãe e filho. Segundo a Organização Mundial de Saúde (OMS), a amamentação deve ser exclusiva até os seis primeiros meses de vida, sendo o único alimento necessário para a alimentação infantil por ser composto de: vitaminas, carboidratos, minerais, gorduras e água (BRASIL, 2019).

A importância do aleitamento materno exclusivo ( $\mathrm{AME}$ ) vem sendo destacada ao longo dos anos devido a seus benefícios, que se iniciam desde os primeiros dias após o parto. O colostro é produzido nos primeiros cinco dias após o parto e é considerado a primeira imunização do recém-nascido por conta da alta concentração de anticorpos presentes, além de auxiliar no desenvolvimento intestinal e na eliminação do mecônio, as primeiras fezes do bebê. O leite maduro, contém proteína, lactose, vitaminas, minerais, água, gordura e oferece proteção imunológica à criança de inúmeras doenças, como as crônicas, respiratórias, alergias e câncer com impactos sobre a morbimortalidade infantil (SANTOS; SCHEID, 2019; COSTA et al., 2013).

Além dos benéficos do aleitamento para o recém-nascido, o ato de amamentar possui diversos benefícios para as mães, como a involução uterina, recuperação de peso pré-gestacional, redução das chances de câncer de mama e nos ovários e desenvolvimento de um vínculo afetivo com o bebê (REA, 2004).

Diante da importância do AME, o enfermeiro deve orientar a mãe, por meio de práticas educativas, quanto aos benefícios que esse ato traz para mãe e filho, bem como sobre o posicionamento adequado do bebê, pega correta e da livre demanda. Dessa forma, evitam-se complicações decorrentes da amamentação incorreta, como lesões nos mamilos, ingurgitamento mamário, mastite, com possível cessação do aleitamento materno (FRANÇA et al., 2016).

As práticas educativas desenvolvidas pelos enfermeiros constituem um desafio, pois sua abrangência de ação é maior que o campo específico da saúde e envolve uma combinação de estratégias, a saber: ações do Estado (políticas públicas saudáveis), da comunidade (reforço da ação comunitária), de indivíduos (desenvolvimento de habilidades pessoais), do sistema de saúde (reorientação do sistema de saúde) e de parcerias intersetoriais (MASCARENHAS; MELO; FAGUNDES, 2012). 
O profissional de enfermagem tem grande importância nas práticas educativas, e deve estar preparado para fornecer as orientações necessárias com a finalidade de estimular e apoiar a mãe no momento da amamentação e identificar qual a prática de educação é mais efetiva diante das necessidades da mãe, de suas dificuldades e assim criar um plano de cuidados individualizado (DIAS; DIAS; NOGUEIRA, 2019).

O aconselhamento sobre aleitamento materno é de grande relevância, pois, a partir de um diálogo efetivo, é possível realizar modelos assistenciais para o binômio mãe-filho, esclarecer dúvidas visto que a falta de informações é um fator que leva ao desmame precoce, e, ao sanar as dúvidas da nutriz, o enfermeiro possibilita uma amamentação efetiva (BRANDÃO, 2012).

Destarte, a realização da presente pesquisa se justifica pela importância das práticas educativas como estratégia de promoção de saúde e geradoras de mudança de comportamentos e por ser fundamental que o enfermeiro conheça e forneça informações acerca da importância da amamentação e seus benefícios para a mãe e a criança.

O interesse por esse tema foi devido à percepção da importância do enfermeiro na orientação e no incentivo ao aleitamento materno, visto que muitas mães não entendem os benefícios proporcionados pela amamentação tanto para ela quanto para o bebê. O objeto da presente investigação foram as práticas de educação em saúde desenvolvidas por enfermeiros sobre o aleitamento materno exclusivo e o objetivo foi descrever as ações de educação em saúde realizadas por enfermeiros para motivar a aderência ao AME.

Trata-se de uma pesquisa qualitativa do tipo revisão de literatura, que objetivou demonstrar o panorama atual das pesquisas que abordam a temática relacionada ao objeto de pesquisa e discutilo. A revisão da literatura foi realizada nos meses de agosto a outubro de 2019 , atualizada em agosto de 2021, com uma pesquisa no portal da Biblioteca Virtual em Saúde (BVS) e no portal da Coordenação de Aperfeiçoamento de Pessoal de Nível Superior (Capes), nas bases de dados Literatura LatinoAmericana em Ciências de Saúde (Lilacs), Banco de Dados Bibliográficos Especializado na Área de Enfermagem do Brasil (Bdenf) e na Scientific Electronic Library Online (SciELO) no período de 2015 a 2021. Para seleção dos estudos, utilizaram-se como critérios de inclusão: artigos completos em português, inglês e espanhol; dissertações e teses e que estivessem disponíveis eletronicamente nas bases de dados.

Foram critérios de exclusão: as publicações repetidas nas bases pesquisadas, produções tipo estudo de caso, artigos de reflexão, livros e capítulos de livros e publicações que apresentassem falta de 
aderência ao tema investigado. Para a realização da busca, foram utilizados os descritores: “Educação em Saúde", "Enfermagem Materno-Infantil", "Aleitamento Materno", "Enfermagem em Saúde Pública" e "Promoção da Saúde" em combinações por pares. Em seguida, foi realizada uma leitura analítica com a finalidade de categorizar as informações contidas nas fontes, de forma que essas possibilitassem a obtenção de respostas ao problema da pesquisa.

\section{DESENVOLVIMENTO}

Ao combinar os descritores nas bases de dados pesquisadas, foram encontradas 13 publicações, sendo três na Lilacs, três na Bdenf e sete na SciELO conforme apresentado no Quadro 1.

Quadro 1- Panorama atual das pesquisas que abordam ações de educação em saúde desenvolvidas por enfermeiros direcionadas ao AME, segundo base de dados, periódico, título do artigo e autores de acordo com critérios de seleção.

\begin{tabular}{|l|l|l|l|}
\hline \multicolumn{1}{|c|}{$\begin{array}{c}\text { Base de } \\
\text { Dados }\end{array}$} & \multicolumn{1}{|c|}{ Revista } & \multicolumn{1}{|c|}{ Título do Artigo } & \multicolumn{1}{c|}{ Autos e Ano } \\
\hline SciELO & $\begin{array}{l}\text { Seção Artigos } \\
\text { Originais }\end{array}$ & $\begin{array}{l}\text { Educação Permanente } \\
\text { em Saúde: Instrumento } \\
\text { de transformação do } \\
\text { trabalho de enfermeiro. }\end{array}$ & $\begin{array}{l}\text { PUGGINA CC, AMESTOY } \\
\text { SC, FERNANDES HN et al, } \\
2015 .\end{array}$ \\
\hline SciELO & $\begin{array}{l}\text { ANAIS dos Cocifa } \\
2018\end{array}$ & $\begin{array}{l}\text { Intervenções do } \\
\text { Enfermeiro no } \\
\text { Aleitamento Materno } \\
\text { Exclusivo. }\end{array}$ & $\begin{array}{l}\text { SILVA CR, LIMA MR, LOBO } \\
\text { MRG, 2018. }\end{array}$ \\
\hline SciELO & $\begin{array}{l}\text { Ciência e Saúde } \\
\text { Coletiva }\end{array}$ & $\begin{array}{l}\text { Impacto de estratégias } \\
\text { educacionais no pré- } \\
\text { natal de baixo risco: } \\
\text { revisão sistemática de } \\
\text { ensaios clínicos } \\
\text { randomizados. }\end{array}$ & $\begin{array}{l}\text { SILVA EP, LIMA RT, } \\
\text { OSÓRIO MM, 2016. }\end{array}$ \\
\hline Lilacs & $\begin{array}{l}\text { Revista Oficial do } \\
\text { Conselho Federal } \\
\text { de Enfermagem }\end{array}$ & $\begin{array}{l}\text { Caracterização clínica e } \\
\text { epidemiológica da } \\
\text { mastite puerperal em } \\
\text { uma maternidade de } \\
\text { referência. }\end{array}$ & $\begin{array}{l}\text { MOTA TC, NERY IS, } \\
\text { SANTOS JDM et al., 2019. }\end{array}$ \\
\hline Bdenf & $\begin{array}{l}\text { Revista Brasileira } \\
\text { Interdisciplinar de } \\
\text { Saúde }\end{array}$ & $\begin{array}{l}\text { Aleitamento Materno é } \\
\text { mais que um direito: um } \\
\text { benefício para toda a } \\
\text { família. }\end{array}$ & $\begin{array}{l}\text { RODRIGUES GMS, LIMA } \\
\text { OF, AOYMA EA et al., } \\
\text { 2019. }\end{array}$ \\
\hline
\end{tabular}




\begin{tabular}{|c|c|c|c|}
\hline SciELO & $\begin{array}{l}\text { Revista on-line de } \\
\text { pesquisa }\end{array}$ & $\begin{array}{l}\text { Atuação do enfermeiro } \\
\text { no manejo clínico da } \\
\text { amamentação: } \\
\text { estratégias para o } \\
\text { aleitamento materno. }\end{array}$ & $\begin{array}{l}\text { COSTA EFG, ALVES VH, } \\
\text { SOUZA RMP et al } 2018 .\end{array}$ \\
\hline Lilacs & Revista Nursing & $\begin{array}{l}\text { Percepção da equipe de } \\
\text { enfermagem frente ao } \\
\text { aleitamento materno: do } \\
\text { conhecimento à } \\
\text { implementação. }\end{array}$ & $\begin{array}{l}\text { FASSARELLA BPA, } \\
\text { RIBEIRO WA, PIMENTA } \\
\text { ESS et al., } 2018 .\end{array}$ \\
\hline SciELO & $\begin{array}{l}\text { Revista Paulista } \\
\text { de Pediatria }\end{array}$ & $\begin{array}{l}\text { Primeira Visita Domiciliar } \\
\text { Puerperal: Uma } \\
\text { estratégia protetora do } \\
\text { aleitamento materno } \\
\text { exclusivo. }\end{array}$ & $\begin{array}{l}\text { CARVALHO MJLN, } \\
\text { CARVALHO MF, SANTOS } \\
\text { CR et al., } 2018 .\end{array}$ \\
\hline SciELO & $\begin{array}{l}\text { Ciências e saúde } \\
\text { coletiva }\end{array}$ & $\begin{array}{l}\text { Conhecimento de } \\
\text { enfermeiras e } \\
\text { estratégias de incentivo } \\
\text { da participação familiar } \\
\text { na amamentação. }\end{array}$ & $\begin{array}{l}\text { DIAS RB, BOERY RNSO, } \\
\text { VILELA ABA, } 2016 .\end{array}$ \\
\hline Bdenf & $\begin{array}{l}\text { Revista da Escola } \\
\text { de Enfermagem } \\
\text { da USP }\end{array}$ & $\begin{array}{l}\text { Binômios atendidos por } \\
\text { consultores em lactância } \\
\text { e interrupção da } \\
\text { lactância materna } \\
\text { exclusiva no primeiro } \\
\text { mês. }\end{array}$ & $\begin{array}{l}\text { GASPARIN VA, STRADA } \\
\text { JKR, MORAES BA et al., } \\
2019 .\end{array}$ \\
\hline Bdenf & $\begin{array}{l}\text { Revista de } \\
\text { enfermagem do } \\
\text { centro-oeste } \\
\text { mineiro }\end{array}$ & $\begin{array}{l}\text { Aleitamento Materno: } \\
\text { percepção do pai sobre } \\
\text { seu papel. }\end{array}$ & $\begin{array}{l}\text { TESTON EF, REIS TS, } \\
\text { GÓIS LM et al., } 2018 .\end{array}$ \\
\hline Lilacs & $\begin{array}{l}\text { Revista Brasileira } \\
\text { de Ciências da } \\
\text { Saúde. }\end{array}$ & $\begin{array}{l}\text { Aleitamento Materno: } \\
\text { Conhecimento das } \\
\text { Gestantes Sobre a } \\
\text { Importância da } \\
\text { Amamentação na } \\
\text { Estratégia de Saúde da } \\
\text { Família. }\end{array}$ & $\begin{array}{l}\text { SILVA KMS, GOETZ ER, } \\
\text { SANTOS MVJ, } 2017 .\end{array}$ \\
\hline SciELO & Revista Uniplac & $\begin{array}{l}\text { Mastite Granulomatosa } \\
\text { Idiopática. }\end{array}$ & FURLANETTO ME, 2016. \\
\hline
\end{tabular}


Após leitura atenta dos artigos selecionados sobre a temática do presente estudo, emergiram as seguintes categorias: importância da educação em saúde no AME e atuação do enfermeiro no AME.

\subsection{IMPORTÂNCIA DA EDUCAÇÃO EM SAÚDE NO AME}

A atuação do profissional de enfermagem deve abordar a promoção e a proteção da amamentação e o fornecimento de apoio emocional durante essa prática, visando contribuir para a superação de obstáculos no processo de amamentar, como fatores culturais, sociais e/ou econômicos que podem prejudicar a prática da amamentação. Apenas fornecer informações não é o suficiente para que as mães sejam motivadas a amamentar, é necessária uma estratégia por meio do acolhimento e da escuta ativa, com a qual o enfermeiro crie um plano de cuidados específico, disponibilize orientações necessárias, destacando os aspectos biológicos e técnicos da amamentação para que a nutriz seja a corresponsável pelo cuidado (COSTA et al., 2018).

O enfermeiro é o profissional de saúde que tem maior contato com a mulher durante o processo gestacional e puerpério, portanto suas estratégias e intervenções de educação em saúde devem atingir o núcleo familiar da nutriz. É preciso, portanto, que o profissional de saúde acolha os familiares no momento das realizações de orientações, durante as consultas de pré-natal, e ressalte a importância do fortalecimento do vínculo familiar para a amamentação, a fim de que os desafios vivenciados durante o processo de amamentação sejam vencidos em conjunto (TESTON, 2018).

De acordo com Fassarella et al. (2018), o enfermeiro precisa ter um olhar atento e abrangente, levando em consideração, além dos aspectos emocionais, culturais e familiares da nutriz, o conhecimento técnico da lactação. Nesse sentido, a educação em saúde ofertada pela enfermagem aos clientes tem como responsabilidade atualizar e capacitar motivada pelo autoconhecimento, aperfeiçoamento e atualização profissional. É considerada uma estratégia para promover a qualidade dos cuidados prestados, permitindo a atuação em serviço de forma segura e efetiva, proporcionando a aquisição de novos conhecimentos para que se atinja a capacidade profissional e o desenvolvimento pessoal de acordo com a realidade social e institucional. Com isso, a educação em saúde se torna um importante instrumento de mudança (PUGGINA et al., 2015).

O enfermeiro, em seu papel de educador em saúde, promove grupos educativos, sala de espera e visitas domiciliares voltadas para a amamentação, o que gera grande impacto na prática de amamentar. A visita domiciliar atua como fator protetor na manutenção da amamentação exclusiva, é o momento em que o enfermeiro realiza atividades assistenciais e de educação em saúde. Estas 
geram impacto favorável na saúde materna e infantil, por meio da escuta qualificada e da atenção humanizada com esclarecimento de dúvidas e com orientações sobre a técnica correta de amamentar e o suporte nas possíveis intercorrências que podem dificultar o processo do AME (CARVALHO et al., 2018).

Segundo Dias et al. (2016), a enfermagem usa como estratégia para a inserção da família no AME ações de educação em saúde, como grupos educativos e salas de espera, com a finalidade inserir a família no processo de amamentação, visto que a nutriz necessita do apoio familiar para que a amamentação seja efetiva. Com essas atividades, é possível realizar as orientações e os cuidados com a amamentação, propiciando aos acompanhantes a oportunidade de sanarem suas dúvidas e se envolverem mais nesse processo.

\subsection{ATUAÇÃO DO ENFERMEIRO NO AME}

Segundo a OMS, o Fundo das Nações Unidas para a Infância (Unicef) e o Ministério da Saúde (MS), o AME é recomendado durante os seis primeiros meses de vida do bebê, não sendo necessário qualquer complemento alimentar, como água, chás e alimentos. O leite materno tem todos os suprimentos nutricionais para o bebê, além de reduzir as taxas de mortalidade infantil, estimular o crescimento e desenvolvimento da criança e fortalecer o vínculo afetivo entre mãe e filho (GASPARIN, 2019).

O enfermeiro tem como foco principal as ações assistenciais e educativas voltadas à lactante, que devem ser direcionadas a pega e sucção, amamentação correta e posicionamento adequado do bebê, esvaziamento apropriado das mamas, orientações e importância dos intervalos das mamadas e AME, além de orientações sobre os fatores que contribuem para a descida do leite, uso do próprio leite como cicatrizante do mamilo fissurado. A técnica inadequada é a causa da maioria das dificuldades do aleitamento para a mãe, levando a problemas mamários, como a mastite, ingurgitamento mamário, que pode causar o desmame precoce (SILVA; LIMA; LOBO, 2018). A técnica correta quanto ao local de pega do peito na amamentação foi apresentada na Figura 1. 


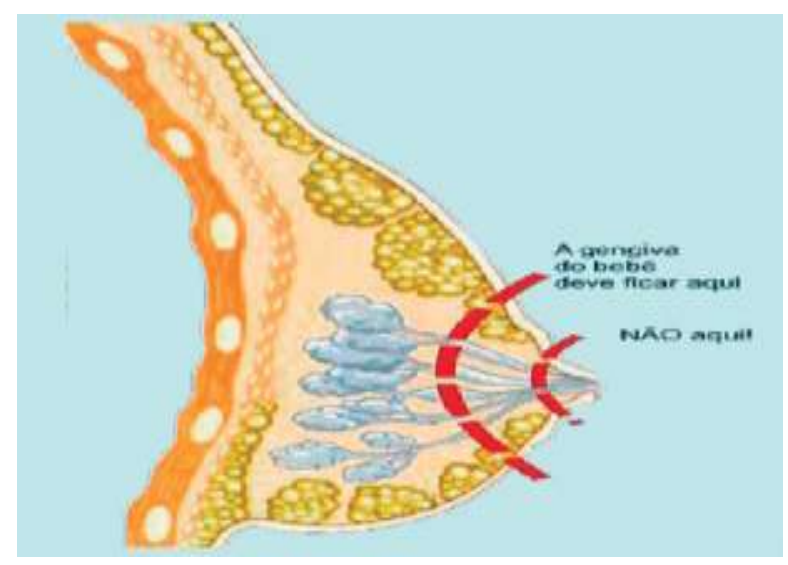

Fonte: BRASIL, 2015, p.26

Para que a amamentação seja eficaz, o enfermeiro deve orientar a mãe no sentido de que ela ocorra em um local tranquilo, onde a nutriz se sinta confortável. Deve ainda indicar a posição correta da pega, que é quando o bebê consegue abocanhar toda a região do mamilo e o seio aprofunda em sua boca, permitindo uma melhor sucção, retirada do leite e estimulação da produção do leite (SILVA; GOETZ; SANTOS, 2017).

De acordo com o manual de amamentação de 2015, a má pega pode dificultar o esvaziamento da mama, gerando diminuição da produção do leite e consequentemente a perda de peso do bebê. 0 esvaziamento correto da mama é de extrema importância para prevenir a mastite e o ingurgitamento mamário (BRASIL, 2015).

A mastite é a infeção mais frequente no puerpério e pode ocorrer nas primeiras semanas de amamentação, é definida como um processo inflamatório dos lóbulos glandulares e pode ser classificada em infecciosa e não infecciosa. Na mastite infecciosa, ocorre penetração de microorganismos nas glândulas mamárias, que são os responsáveis pela inflamação; já na não infecciosa, ocorre o acúmulo de leite nos ductos mamários, ocasionando inflamação e ingurgitamento mamário, que é caracterizado pelo acúmulo de leite nas mamas, causando dor (MOTA et al., 2019).

Conforme o Manual da Amamentação de 2015, para que maiores complicações não ocorram, é necessário ofertar o leite em livre demanda por intervalos inferiores a três horas; aplicar compressas úmidas e mornas sobre a área afetada por 10 a 15 minutos, em seguida, compressas geladas pelo mesmo tempo, depois massagear a cada mama delicadamente, com movimentos circulares, e, logo após, tentar retirar o leite. O procedimento deverá ser mantido até que a mãe se sinta aliviada. Se necessário, o médico pode prescrever o uso de analgésicos antes de proceder à auto-ordenha (FURLANETTO, 2016). 
O profissional de enfermagem deve orientar a mãe quanto à descida do leite, que ocorre de três a quatro dias após o parto, o que pode fazer com que a mãe acredite que não produz leite. Dessa forma, não colocará o bebê no peito e isso impedirá a estimulação de produção de leite, por isso a relevância do profissional de saúde para desenvolver a confiança da mãe e orientar quanto à importância da estimulação da sucção frequente do bebê e da ordenha. Quando o bebê inicia a sucção, as terminações nervosas do seio se ligam ao cérebro, produzindo o hormônio ocitocina, que é responsável pelas contrações musculares mamárias que comprimem os alvéolos e os lóbulos, proporcionando a descida do leite (RODRIGUES et al., 2019).

As ações do enfermeiro voltadas para promoção do AME devem ser promovidas desde o acolhimento da gestante no momento das consultas de pré-natal, oportunidade em que o enfermeiro acompanha adequadamente a gestante, desenvolve um planejamento exclusivo para ela, com orientações necessárias sobre os benefícios do AME e promove a autoconfiança e autocuidado. Assim, é possível prevenir e identificar intercorrências mamárias. A realização de práticas educativas como grupos de gestantes e visitas domiciliares contribuem para resultados satisfatórios para o AME por minimizarem dúvidas e ansiedades da mulher durante o processo de gestação até o ato de amamentar (SILVA; LIMA; OSÓRIO, 2016).

\section{CONSIDERAÇÕES FINAIS}

As práticas de educação em saúde desenvolvidas por enfermeiros para a aderência ao AME são importantes estratégias de promoção de saúde e geradoras de mudança de comportamentos. Por isso, é fundamental que o enfermeiro conheça e forneça informações acerca da importância da amamentação e de seus benefícios para o binômio mãe-bebê.

Esta pesquisa tem como contribuição o levantamento de conhecimentos sobre as ações de educação em saúde desenvolvidas por enfermeiros relacionados ao AME. A limitação desta investigação se prende ao delineamento metodológico, do tipo revisão. Sendo assim, sugere-se a produção de mais estudos, que se utilizem de pesquisa de campo, com foco na importância do enfermeiro nas práticas educativas voltadas para o AME. 


\section{REFERÊNCIAS}

BRANDÃO EC, SILVA GRF, GOUVEIA MTO et al. Caracterização da comunicação no aconselhamento em amamentação. Revista Eletrônica de Enfermagem. 2012 abr/jun;14(2):355-65. Acesso em 30/10/2019. Disponível em: https://www.fen.ufg.br/revista/v14/n2/v14n2a16.htm

BRASIL. Ministério da Saúde. Aleitamento materno 2019. Acesso em: 15/09/2019. Disponível em: http://portalarquivos.saude.gov.br/campanhas/amamentacao/

BRASIL. Ministério da Saúde. Cadernos de Atenção Básica. Saúde da Criança Aleitamento Materno e Alimentação Complementar. Brasília: Ministério da Saúde, 2015. Acesso em 2/10/2019. Disponível em http://bvsms.saude.gov.br/bvs/publicacoes/aleitamento_materno_alimentacao_complementar_2ed icao.pdf

COSTA, EFG et al. Atuação do enfermeiro no manejo clínico da amamentação: estratégias para o aleitamento materno. Rev. Fund Care Online. 2018 jan./mar.; 10(1): 217-223. Acesso em 07/10/2019. Disponível

em:

file://C:/Users/Positivo/Downloads/Nursing_practice_in_clinical_management_of_breastf.pdf

COSTA, LKO et al. Importância do aleitamento materno exclusivo: uma revisão sistemática da literatura Rev. Ciênc. Saúde, São Luís, v.15, n.1, p. 39-46, jan-jun, 2013. Acesso em: 16/09/2019. Disponível em: http://www.periodicoseletronicos.ufma.br/index.php/rcisaude/article/view/1920

CARVALHO, MJLN et al. Primeira Visa Domiciliar Puerperal: Uma estratégia protetora do aleitamento materno exclusivo. Revista Paulista de Pediatria. vol.36 no.1 São Paulo jan./mar. 2018 Epub 15-Jan2018. Acesso em 22/10/2019. Disponível em: http://www.scielo.br/pdf/rpp/v36n1/0103-0582-rpp2018-36-1-00001.pdf

DIAS, CMNM; DIAS, GLB; NOGUEIRA, MS. Atuação do Enfermeiro no estímulo da Amamentação Exclusiva até o sexto mês de vida. Anais do 15 Simpósio de TCC e 8 Seminário de IC do Centro Universitário ICESP. 2019(15); 877-880. Acesso em 15/09/2019. Disponível em: http://nippromove.hospedagemdesites.ws/anais_simposio/arquivos_up/documentos/artigos/d308f ff61cdf8d78860422fb31aa8c64.pdf

DIAS, RB; BOERY, RNSO; VILELA, ABA. Conhecimento de enfermeiras e estratégias de incentivo da participação familiar na amamentação. Ciências e saúde coletiva 2016. Disponível em: http://www.scielo.br/pdf/csc/v21n8/1413-8123-csc-21-08-2527.pdf. Acesso 22/10/2019.

FASSARELLA, BPA. Percepção da equipe de enfermagem frente ao aleitamento materno: do conhecimento à implementação. Revista Nursing 2018. Disponível em https://pesquisa.bvsalud.org/portal/resource/pt/biblio-970871. Acesso em 09/10/2019.

FRANÇA, AFSS et al. Contribuições da Educação em Saúde por Enfermeiros na adesão ao Aleitamento Materno. Rev. Ciênc. Saúde Nova Esperança - abr. 2016;14(1):73-8. Disponível em: http://www.facene.com.br/wp-content/uploads/2010/11/8.-CONTRIBUICOES-DA-EDUCA\%C3\%87\%C3\%830-EM-SA\%C3\%9ADE_PRONTO.pdf.

FURLANETTO ME. Revista Uniplac. V.14, n.1 2016. Disponível em: http://revista.uniplac.net/ojs/index.php/uniplac/article/view/2552. Acesso em 31/10/2019. 
GASPARIN, VA et al. Binômios atendidos por consultores em lactância e interrupção da lactância materna exclusiva no primeiro mês. Revista da Escola de Enfermagem da USP, vol.53 São Paulo 2019 Epub 21 de janeiro de 2019. Disponível em:

http://www.scielo.br/scielo.php?script=sci_arttext\&pid=S0080-62342019000100403\#fn1. Acesso em 23/10/2019.

MASCARENHAS, NB; MELO, CMM; FAGUNDES NC. Produção do conhecimento sobre promoção da saúde e prática da enfermeira na atenção primaria. Revista Brasileira de Enfermagem, vol.65, núm 6, Brasilia Brasil, 2012. Disponível em: http://www.scielo.br/pdf/reben/v65n6/a16v65n6.pdf. Acesso em 16/09/2019.

MOTA, TC et al. Caracterização clínica e epidemiológica da mastite puerperal em uma maternidade de referência. Revista Oficial do Conselho Federal de Enfermagem. V. 10, n. 2 2019. Teresina PI. Disponível em: http://revista.cofen.gov.br/index.php/enfermagem/article/view/1331/512. Acesso em: 30/10/2019.

PUGGINA CC, et al. Educação Permanente em Saúde: Instrumento de transformação do trabalho de enfermeiro. Seção Artigos Originais, 2015. Disponível em:

http://espacoparasaude.fpp.edu.br/index.php/espacosaude/article/view/386. Acesso: 19/10/2019.

REA, MF. Os benefícios da amamentação para a saúde da mulher. Jornal de Pediatria (Rio J). 2004; 80(5 Supl):S142-S146. Disponível em: http://www.scielo.br/pdf/jped/v80n5s0/v80n5s0a05. Acesso em 29/10/2019.

RODRIGUES, GMS et al. Aleitamento Materno é mais que um direito: um benefício para toda a família. Revista Brasileira Interdisciplinar de Saúde. ReBIS. 2019;1(1):1-8 Brasília DF. Disponível em: https://revista.rebis.com.br/index.php/rebis/article/view/121/45. Acesso em 30/10/2019.

SANTOS, PP; SCHEID, MMA. Importância do aleitamento materno exclusivo nos primeiros seis meses de vida para a promoção da saúde da mãe e bebê. J Health Sci Inst. 2019;37(3):276-80. Disponível em: https://repositorio.unip.br/wp-content/uploads/2020/12/15V37_n3_2019_p276a280.pdf. Acesso em 05/05/2021.

SILVA, CR; LIMA, MR; LOBO, MRG. Intervenções do Enfermeiro no Aleitamento Materno Exclusivo. Anais dos CONCIFA v.1 n.1 2018. Disponível em:

http://periodicos.fametro.edu.br/index.php/AE/article/view/52. Acesso em 07/10/2019.

SILVA, EP; LIMA, RT; OSÓRIO, MM. Impacto de estratégias educacionais no pré-natal de baixo risco: revisão sistêmica de ensaios clínicos randomizados. Ciência e Saúde Coletiva. Vol.21 n 9 Rio de Janeiro set. 2016. Disponível em: https://doi.org/10.1590/1413-81232015219.01602015. Acesso em $30 / 10 / 2019$.

SILVA, KMS; GOETZ, ER; SANTOS, MVJ. Aleitamento Materno: Conhecimento das Gestantes Sobre a Importância da Amamentação na Estratégia de Saúde da Família. Revista Brasileira de Ciências da Saúde. V. 21 n. 2 Pag. 111-118 2017 ISNN 1415-2177 Santa Catarina. Disponível em: https://periodicos.ufpb.br/ojs/index.php/rbcs/article/view/18116/17222. Acesso em 31/10/2019. 
TESTON, EF et al. Aleitamento Materno: Percepção do pai sobre seu papel. Revista de Enfermagem do centro-oeste Mineiro (RECOM). 2018;8:e2723. Disponível em:

http://seer.ufsj.edu.br/index.php/recom/article/view/2723/2042. Acesso em 30/10/2019. 


\section{Capítulo 5}

\section{doi $10.37423 / 210804681$}

\section{ATUAÇÃO DO ENFERMEIRO DA ATENÇÃO PRIMÁRIA NA ASSISTÊNCIA À CRIANÇA COM DIABETES TIPO 1: FOCO NA QUALIDADE DE VIDA}

Ana Carolina de Barros Nunes

Lidia da Dalt Martins Tostes

Luisa Maria Castro de Mtexddpça

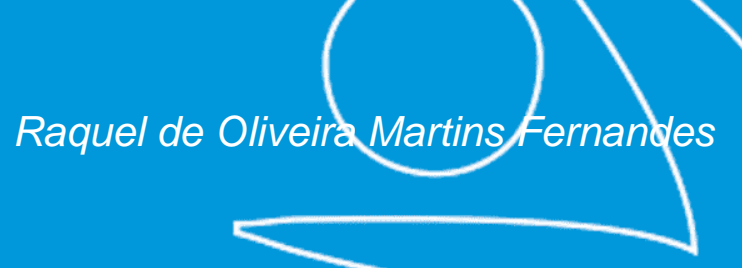

Laércio Deleon de Mieto

Paula Krempser

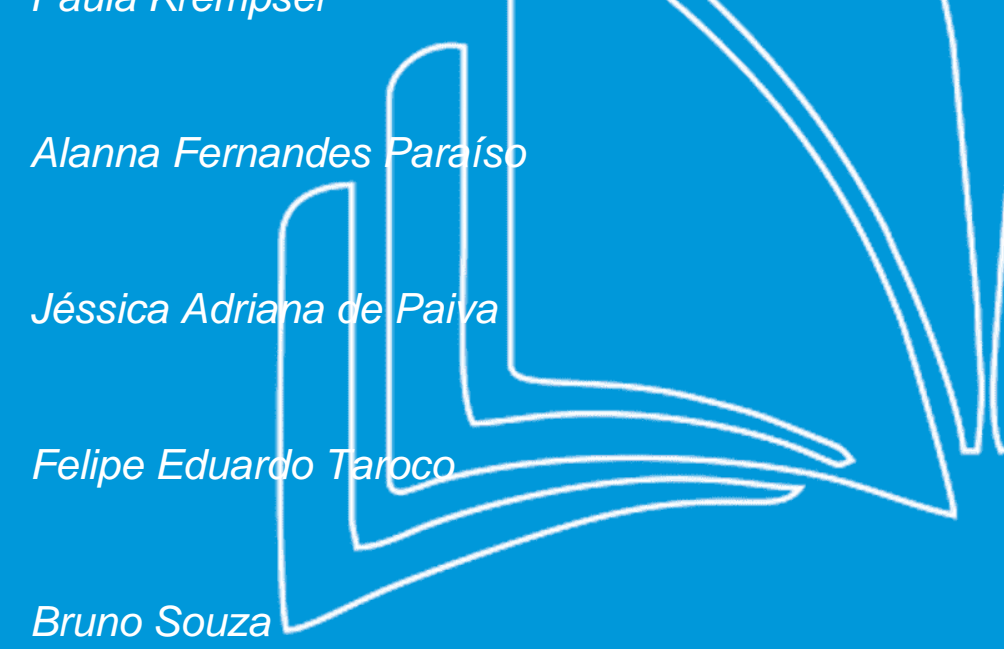

Centro Universitário Estácio de Juiz de Fora

Centro Universitário Estácjo de Juiz de Fora

Centro Univgrsitárjb Estaciode Juiz de Fora

Universidade Federal d'e Juiz de Fora

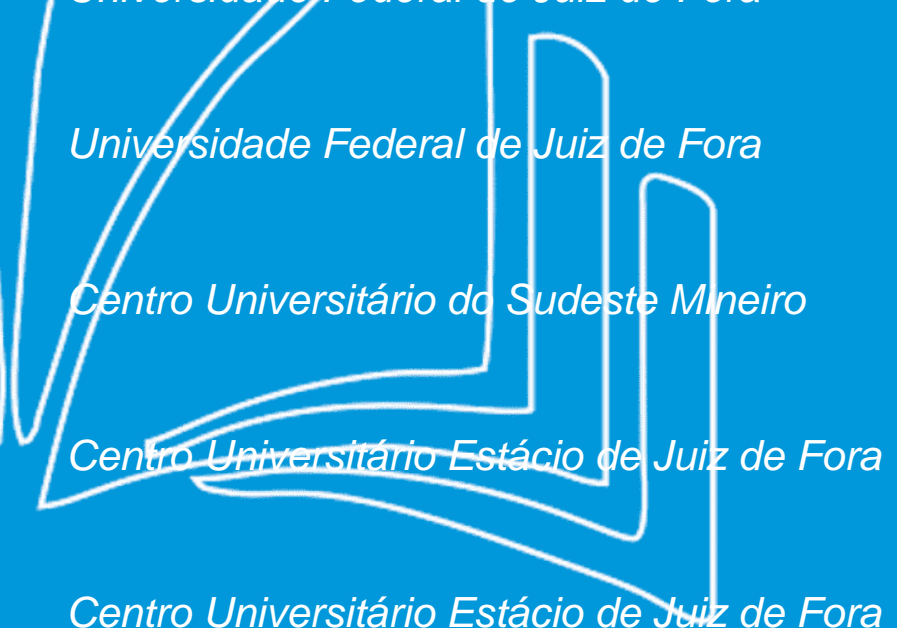




\section{Resumo:}

Introdução: esse estudo exibe a visão sobre a qualidade de vida de crianças com Diabetes Mellitus Tipo 1 (DM1) em seus vários aspectos e aponta caminhos para o enfermeiro acompanhar esses pacientes durante a assistência de enfermagem na atenção primária. Objetivo: evidenciar o papel do enfermeiro na atenção primária no tratamento dos pacientes com DM1 com foco na qualidade de vida. Metodologia: trata-se de uma revisão bibliográfica da literatura do tipo integrativa, na qual foram utilizados os descritores com base no DeCS: "Diabetes Mellitus", "Criança”, "Atenção Primária", "Qualidade de vida", "Papel do enfermeiro" e "Familiares", formando combinações com o conector booleano AND. Incluíram-se 20 artigos científicos publicados entre 2016 e 2020, encontrados no acesso eletrônico das bases de dados: Sistema Latino-Americano e do Caribe de Informação em Ciências da Saúde (Lilacs), Banco de Dados em Enfermagem (Bdenf) e biblioteca eletrônica SciELO. A síntese do conhecimento foi apresentada de forma estruturada em: 1) O diabetes mellitus: conceito, diagnóstico e tratamento, 2) A criança e o diabetes mellitus e 3) Atuação do enfermeiro da Atenção Primária na assistência à criança com DM1, visando à qualidade de vida. Considerações Finais: a pesquisa constatou a importância do enfermeiro na assistência relacionada ao DM1, nas orientações sobre o autocuidado, no entendimento à criança portadora da patologia, no apoio à família desta, abrangendo todas as ações necessárias ao tratamento da criança. 


\section{INTRODUÇÃO}

Considerada uma das principais causas de mortes no mundo segundo a Organização Mundial da Saúde (OMS), a diabetes mellitus é uma doença crônica de característica metabólica causada pela incapacidade parcial ou total na produção de insulina no pâncreas, a qual é um dos principais hormônios produzidos no corpo. No Brasil, estima-se que a patologia compromete 16 milhões de pessoas com um aumento crescente de 61,8\% nos últimos dez anos (OKIDO et al., 2017; FIOCRUZ, 2018).

O Atlas 2017 da Federação Internacional de Diabetes aponta que 8,8\% da população no mundo com 20 a 79 anos convive com a diabetes e estima que, se esses dados se mantiverem em 25 anos, aproximadamente 630 milhões de pessoas terão que se tratar de diabetes mellitus.

Segundo as diretrizes da Sociedade Brasileira de Diabetes (SBD, 2020), o tipo de diabetes mellitus que geralmente acomete as crianças é a diabetes mellitus tipo 1 (DM1), que aparece entre 5 a $10 \%$ dos casos. Nessa faixa etária, embora seja difícil a percepção dos sintomas, por estes serem confundidos com aqueles próprios de mudanças biológicas, tal como a poliúria, polidipsia, polifagia e emagrecimento, é extremamente importante que o diagnóstico seja feito o mais precoce possível (PEREIRA; FIGUEIREDO, 2017).

O tratamento para a DM1 é feito por meios farmacológicos e não farmacológicos. A intenção é que os níveis glicêmicos permaneçam controlados, proporcionando mais qualidade de vida. De acordo com as fontes pesquisadas, a insulinoterapia é um dos recursos terapêuticos mais importantes para o controle da doença. Ela é uma das etapas determinantes do tratamento, mas o fator primordial é um controle alimentar alinhado com a prática diária de exercícios físicos (CUNHA et al., 2017).

Receber esse diagnóstico na infância afeta a vivência por completo dos pacientes, uma vez que, acometidas por uma doença crônica e grave nessa fase, as crianças ficam bastante vulneráveis ao aparecimento de outras doenças com mais facilidade. Além disso, o entendimento da necessidade de nova rotina e a adaptação a ela influenciam também o desenvolvimento psicossocial da criança (PEREIRA; FIGUEIREDO, 2017).

Por se tratar de uma doença grave cujo tratamento é desconfortante e inclui cuidados diários intensos, ela traz diversos transtornos e adaptações à vivência da criança. Entre esses transtornos, podem-se citar o familiar, já que os pais podem divergir nos cuidados com o filho ou não ter tempo para se dedicarem a um tratamento tão severo. A rotina dessa criança sofre diversas mudanças, 
principalmente no que concerne à alimentação, visto que suas preferências alimentares nem sempre serão atendidas. Isso pode acarretar nela um sentimento de revolta e tristeza, modificando o cotidiano de toda a família (QUEIROZ et al., 2016).

A criança precisa do acompanhamento do enfermeiro para auxiliar no seu autocuidado, juntamente com a família. Também na transição da infância para a adolescência, esse atendimento se faz fundamental, pois podem surgir alguns conflitos internos, como a reclusão do jovem por causa da doença, resultando em um sentimento de revolta (COLLET et al., 2018).

O papel do enfermeiro como educador é muito relevante para que a criança e os familiares sigam corretamente as orientações. Ele pode fornecer-lhes todas as informações necessárias ao enfrentamento da doença, assim como ensinar as medições de glicose, aplicações de insulina e orientá-los quanto à realização de atividade física e ao descarte correto dos perfurocortantes (ORTIZ et al., 2017).

O enfermeiro deve estar pronto a acompanhar e tirar todas as dúvidas das pessoas envolvidas nesse contexto, mostrando-Ihes que é possível se adaptar a essa nova realidade e ter uma boa qualidade de vida, estimulando também a criança a ter autocuidado, para que não fique dependente futuramente de seus responsáveis. Deve também motivar a criança e o familiar desta, informando-os de que, seguindo todo o planejamento do tratamento, com o passar do tempo, ficará mais fácil lidar com a patologia e sempre alertando sobre os riscos das complicações (ORTIZ et al., 2017). Nesse sentido, justifica-se a relevância da realização deste estudo para a prática do enfermeiro na assistência à criança com diabetes mellitus, a qual, por conta disso, enfrenta uma série de desafios.

A motivação da escolha do tema surgiu de uma situação experienciada pelos pesquisadores, quando uma criança de seu convívio descobriu que era portadora de DM1. Os pais só obtiveram o diagnóstico da criança quando ela teve uma hiperglicemia e precisou de assistência hospitalar de emergência. Eles relataram ser muito difícil a adaptação à nova realidade de vida da criança, porém fazem de tudo para que ela tenha uma boa qualidade de vida. Sabe-se que essa doença gera mudanças no cotidiano dos pacientes e suas famílias e, portanto, torna-se necessária a adaptação às novas condições de vida e a aderência ao tratamento.

O objetivo da pesquisa é evidenciar o papel do enfermeiro na atenção primária no tratamento dos pacientes com DM1 com foco na qualidade de vida. Para conduzir a busca de artigos, foi elaborada a questão norteadora: Como é a atuação do enfermeiro na assistência à criança com diabetes tipo 1 com foco na qualidade de vida? 
Esta investigação foi delineada como uma revisão de literatura do tipo integrativa. Foram atendidas as seis etapas da metodologia: 1) Identificação do tema e seleção da questão norteadora, 2) Estabelecimento dos critérios de inclusão, amostra e buscas, 3) Definição de informações a serem extraídas dos artigos selecionados e categorização dos estudos, 4) Avaliação dos artigos, 5) Interpretação dos resultados e 6) Apresentação da síntese do conhecimento científico.

A pesquisa foi realizada nos meses de agosto e setembro de 2020, utilizou-se o acesso eletrônico das seguintes bases de dados: Sistema Latino-Americano e do Caribe de Informação em Ciências da Saúde (Lilacs), Banco de Dados em Enfermagem (Bdenf) e Scientific Electronic Library Online (SciELO).

Para identificação e seleção das publicações, foram utilizados os descritores em português cadastrados nos Descritores em Ciências da Saúde (DeCS): "Diabetes Mellitus", "Criança" "Atenção Primária”, "Qualidade de vida", "Papel do enfermeiro" e "Familiares", que foram combinados por meio do conector booleano "AND" nas referidas bases de dados.

Os critérios de inclusão definidos para a busca em todas as bases de dados foram: artigos que destacassem a atuação do enfermeiro na assistência à criança com DM1, focando a qualidade de vida; idioma português; publicados nos últimos cinco anos (2015 a 2020), com texto completo e gratuitos. Artigos indexados em mais de uma base de dados foram considerados apenas uma vez. Utilizaram-se também documentos oficiais, como os da Sociedade Brasileira de Diabetes, do Ministério da Saúde, do Coren/Cofen e da Associação Americana de Diabetes.

Foram excluídos artigos publicados antes de 2015; artigos que não respondiam à questão norteadora da pesquisa e aqueles que não contribuíram para a discussão e o alcance do objetivo investigado. Após o cruzamento dos descritores, o número total de artigos encontrados nas três bases de dados, de acordo com a Figura 1, foi de 228 artigos. Aplicando os critérios de inclusão e exclusão, desse total, foram selecionadas sete publicações da SciELO, 13 da Lilacs e seis da Bdenf, totalizando 20 artigos para análise neste estudo, pois foram excluídos seis artigos duplicados. 
Figura 1 - Diagrama do resultado da aplicação dos critérios de inclusão e exclusão
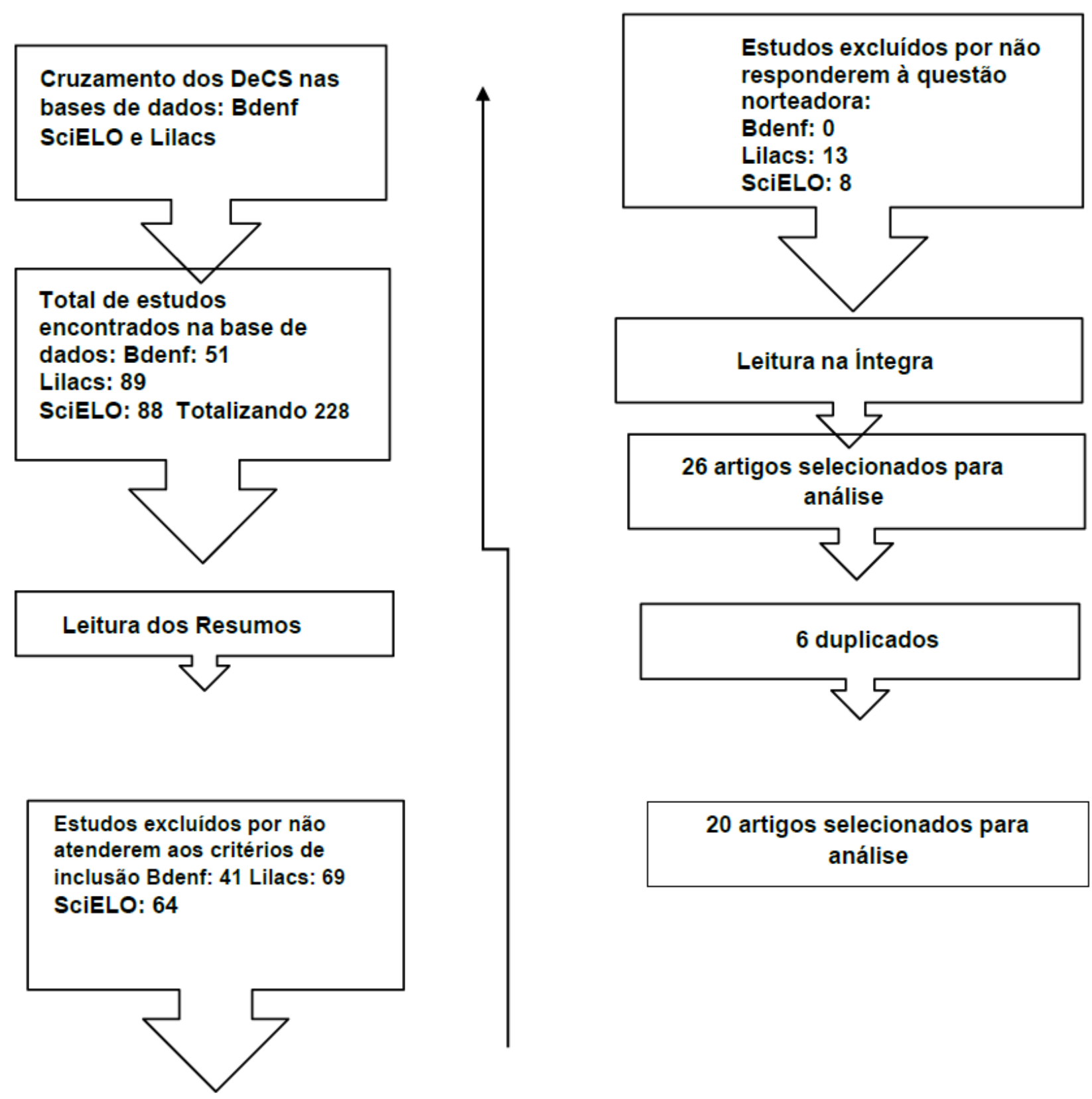

Fonte: As autoras,2020.

\section{DESENVOLVIMENTO}

A partir da análise dos dados coletados, os 20 artigos selecionados foram organizados no Microsoft Office Word 2010 por: autor, periódico, ano, título, objetivos e resultados dos estudos, de acordo com o Quadro 1, para facilitar a sua análise. Os resultados foram interpretados e discutidos a fim de atingir o objetivo deste estudo e contribuir cientificamente para a prática clínica da enfermagem. 
Quadro 1 - Artigos selecionados para a revisão bibliográfica.

\begin{tabular}{|c|c|c|c|}
\hline $\begin{array}{c}\text { Autores/ Periódicos/ } \\
\text { Ano }\end{array}$ & Título & Objetivos & Resultados \\
\hline $\begin{array}{c}\text { WOLKERS, P.C.B.; } \\
\text { PINA, J.C.; WERNET, M.; } \\
\text { FURTADO, M.C.C.;MELLO, } \\
\text { D.F. } \\
\text { Texto e Contexto } \\
\text { Enfermagem, } 2019 .\end{array}$ & $\begin{array}{c}\text { Crianças com } \\
\text { diabetes mellitus } \\
\text { tipo 1: } \\
\text { vulnerabilidade, } \\
\text { cuidado e acesso à } \\
\text { saúde. }\end{array}$ & $\begin{array}{l}\text { Investigar atrajetória } \\
\text { da saúde da criança } \\
\text { com diabetes } \\
\text { mellitus tipo } 1 \text { na } \\
\text { atenção dos serviços } \\
\text { públicos de saúde. }\end{array}$ & $\begin{array}{l}\text { Relatou sofrimento, } \\
\text { desafio e fez } \\
\text { apontamentos de } \\
\text { como é a doença. } \\
\text { Acesso pouco } \\
\text { resolutivo e } \\
\text { insegurança nas } \\
\text { situações de } \\
\text { urgência e } \\
\text { emergência. }\end{array}$ \\
\hline $\begin{array}{l}\text { COLLET, N; BATISTA, } \\
\text { A.F.M.B; NÓBREGA, } \\
\text { V.M; SOUZA, M.H.N; } \\
\text { FERNANDES, L.T.B } \\
\text { Revista da Escola de } \\
\text { Enfermagem da USP,2018. }\end{array}$ & $\begin{array}{l}\text { Autocuidado } \\
\text { apoiado no } \\
\text { manejo da } \\
\text { diabetes tipo } 1 \\
\text { durante a } \\
\text { transição da } \\
\text { infância para } \\
\text { adolescência. }\end{array}$ & $\begin{array}{l}\text { Observar a gestão } \\
\text { do pré-adolescente } \\
\text { em relação ao seu } \\
\text { autocuidado. }\end{array}$ & \begin{tabular}{|c|} 
Constatou a fragilidade \\
emocional do jovem \\
com o tratamento e \\
evidenciou anecessidade \\
de planos de cuidado \\
mais efetivos para que \\
os efeitos do \\
tratamento sejam \\
menos incômodos, \\
ainda mais na transição \\
para \\
adolescência.
\end{tabular} \\
\hline $\begin{array}{l}\text { KANETO, L.A.; DAMIÃO, } \\
\text { E.B.C.; VERISSIMO, } \\
\text { M.L.R.; ROSSATO, L.M.; }\end{array}$ & $\begin{array}{l}\text { Oficina educativa } \\
\text { baseada em } \\
\text { atividades lúcidas }\end{array}$ & $\begin{array}{l}\text { Avaliar o método } \\
\text { educativo baseado } \\
\text { em atividades }\end{array}$ & \begin{tabular}{|l|} 
Foi encontrada uma \\
maior frequência no \\
AMG, na troca da \\
\end{tabular} \\
\hline $\begin{array}{l}\text { TORIYAMA, A.T.M.;SZYLIT, } \\
\text { R. } \\
\text { Revista Latino-Americanade } \\
\text { Enfermagem, } 2018 .\end{array}$ & $\begin{array}{l}\text { melhora o } \\
\text { automonitoramento } \\
\text { glicêmico entre } \\
\text { crianças. }\end{array}$ & $\begin{array}{l}\text { lúcidas para melhoria n } \\
\text { técnicade } \\
\text { automonitoramento } \\
\text { glicêmico (AMG) de } \\
\text { crianças com DM1. }\end{array}$ & \begin{tabular}{l|l} 
lanceta, na variação \\
dos locais de punção, \\
na calibração e \\
verificação periódica \\
de data e hora do \\
monitor da glicemia.
\end{tabular} \\
\hline
\end{tabular}




\begin{tabular}{|c|c|c|c|}
\hline $\begin{array}{l}\text { WOLKERS, P.C.B.; } \\
\text { YAKUWA, M.S.; } \\
\text { PANCIERI, L.; } \\
\text { RODRIGUES, C.M.; } \\
\text { FURTADO, M.C.C.; } \\
\text { MELLO, D.F. } \\
\text { Revista Escola de } \\
\text { Enfermagem da USP,2017. }\end{array}$ & $\begin{array}{l}\text { Crianças com } \\
\text { diabetes mellitus } \\
\text { tipo 1: acesso aos } \\
\text { imunológicos } \\
\text { especiais e à } \\
\text { puericultura. }\end{array}$ & $\begin{array}{l}\text { Avaliar o cuidado } \\
\text { infantil, como se } \\
\text { encontra a vacinação e } \\
\text { o motivo para não } \\
\text { vacinação. } \\
\text { As mães ou } \\
\text { responsáveis mostram } \\
\text { interessesobre o } \\
\text { direito a vacinas } \\
\text { especiais } \\
\text { para crianças comDM1. }\end{array}$ & $\begin{array}{l}\text { Os participantes } \\
\text { relataram usar } \\
\text { serviços mais } \\
\text { especializados e } \\
\text { poucos utilizavam a } \\
\text { saúde básica. Havia } \\
\text { vacinação } \\
\text { incompleta, atraso } \\
\text { das vacinas anuais, } \\
\text { falta da carteira de } \\
\text { vacinação. }\end{array}$ \\
\hline $\begin{array}{l}\text { WOLKERS, P.C.B.; } \\
\text { MACEDO, J.C.B.; } \\
\text { RODRIGUES, C.M.; } \\
\text { FURTADO, M.C.C.; } \\
\text { MELLO, D.F. } \\
\text { Acta Paulista } \\
\text { Enfermagem ,2017. }\end{array}$ & $\begin{array}{l}\text { Atenção primária à } \\
\text { criança com diabetes } \\
\text { mellitus tipo 1: } \\
\text { perspectiva de } \\
\text { cuidadores. }\end{array}$ & $\begin{array}{l}\text { Avaliar como funciona a } \\
\text { qualidade da atenção } \\
\text { primária a crianças com } \\
\text { DM1. }\end{array}$ & $\begin{array}{l}\text { Os participantes } \\
\text { manifestaram } \\
\text { insatisfação com a } \\
\text { maior parte dos } \\
\text { serviços da atenção } \\
\text { primária à saúde, } \\
\text { inclusive nos escores } \\
\text { geral e essencial. }\end{array}$ \\
\hline $\begin{array}{l}\text { VENANCIO, J.M.P.; BANCA, } \\
\text { R.O.; RIBEIRO,C.A. } \\
\text { Escola Anna Nery, } 2017 .\end{array}$ & $\begin{array}{l}\text { Benefícios da } \\
\text { participação em um } \\
\text { acompanhamento no } \\
\text { autocuidado de } \\
\text { crianças e } \\
\text { adolescentes com } \\
\text { diabetes: percepção } \\
\text { das mães. }\end{array}$ & $\begin{array}{l}\text { Acompanhar como é a } \\
\text { rotina das mãesem } \\
\text { relação aos benefícios } \\
\text { do autocuidado, após } \\
\text { terem participado de um } \\
\text { acampamento para } \\
\text { jovens diabéticos. }\end{array}$ & $\begin{array}{l}\text { Relataram a } \\
\text { importância do } \\
\text { acampamento para a } \\
\text { promoção do } \\
\text { autocuidado da/o } \\
\text { criança/adolescente } \\
\text { com diabetes. }\end{array}$ \\
\hline $\begin{array}{l}\text { CRUZ, D.S.M.; COLLET, } \\
\text { N.; ANDRADE, E.M.C.; } \\
\text { NÓBREGA, V.M.; NÓBREGA, } \\
\text { M.M.L. } \\
\text { Escola Anna Nery, } 2017 .\end{array}$ & $\begin{array}{l}\text { Vivências de mãesde } \\
\text { crianças diabéticas. }\end{array}$ & $\begin{array}{l}\text { Entender a rotinadas } \\
\text { mães de crianças com } \\
\text { diabetes. }\end{array}$ & $\begin{array}{l}\text { Esse estudo chama } \\
\text { atenção para o } \\
\text { familiar que mais } \\
\text { cuida da criança, que } \\
\text { é a mãe. O cuidado } \\
\text { precisa ser } \\
\text { multiprofissional, } \\
\text { pois a mãe também } \\
\text { precisa de apoio e } \\
\text { orientação sobre } \\
\text { como cuidar de seu } \\
\text { filho, } \\
\text { principalmente na } \\
\text { quanto à alimentação. }\end{array}$ \\
\hline
\end{tabular}




\begin{tabular}{|c|c|c|c|}
\hline $\begin{array}{l}\text { PENNAFORT, V.P.S.; } \\
\text { QUEIROZ, M.V.O.; } \\
\text { NASCIEMENTO, L.C.; } \\
\text { GUEDES, M.V.C. } \\
\text { Revista Brasileira de } \\
\text { Enfermagem, 2016. }\end{array}$ & $\begin{array}{l}\text { Rede de apoio social } \\
\text { no cuidado familiar } \\
\text { da criançacom } \\
\text { diabetes. }\end{array}$ & $\begin{array}{l}\text { Abranger a influência } \\
\text { da redede apoio social } \\
\text { nocuidado ao paciente } \\
\text { infantil com DM1. }\end{array}$ & $\begin{array}{l}\text { A rede de apoio } \\
\text { social no cuidado à } \\
\text { criança com DM1 } \\
\text { favoreceu o } \\
\text { acompanhamento de } \\
\text { informações, } \\
\text { promovendo bem- } \\
\text { estar e confiança no } \\
\text { cuidado da criança } \\
\text { com a doença. }\end{array}$ \\
\hline $\begin{array}{l}\text { QUEIROS, M.V.O.; } \\
\text { BRITO, L.M.M.C; } \\
\text { PENNAFORT, V.P.S; } \\
\text { BEZERRA, F.S.M. } \\
\text { Escola Anna Nery, } 2016 .\end{array}$ & $\begin{array}{l}\text { Sensibilizando a } \\
\text { criança com } \\
\text { diabetes para o } \\
\text { cuidado de si: } \\
\text { contribuição à } \\
\text { prática educativa }\end{array}$ & $\begin{array}{l}\text { Verificar a sensibilidade } \\
\text { da criança com seu } \\
\text { autocuidado no } \\
\text { tratamento de sua } \\
\text { doença }\end{array}$ & $\begin{array}{l}\text { Os cuidados com a } \\
\text { criança são realizados } \\
\text { pelas mães, e as } \\
\text { criançasnão têm } \\
\text { muita independência } \\
\text { sobre isso. Elas se } \\
\text { sentem muito } \\
\text { incomodadas com o } \\
\text { tratamento e a } \\
\text { pesquisa evidenciou } \\
\text { que o enfermeiro } \\
\text { cuida da criança de } \\
\text { forma mais lúdica, } \\
\text { aumentando a } \\
\text { sensibilidade da } \\
\text { criança e diminuindo } \\
\text { seu sofrimento. }\end{array}$ \\
\hline $\begin{array}{l}\text { BRANCAGLIONIA, } \\
\text { B.C.A; RODRIGUES, } \\
\text { G.C;DAMIÃO, E.B.C; } \\
\text { QUEIROZ, M.S; NERY, } \\
\text { M. } \\
\text { Revista Gaúcha } \\
\text { Enfermagem, } 2016 .\end{array}$ & $\begin{array}{l}\text { Crianças e } \\
\text { adolescentes que } \\
\text { convivem } \\
\text { com diabetes e } \\
\text { doença celíaca }\end{array}$ & $\begin{array}{l}\text { Entender como as } \\
\text { crianças com DM1e } \\
\text { doença celíaca } \\
\text { convivem com o } \\
\text { tratamento da doença } \\
\text { e suas particularidades. }\end{array}$ & $\begin{array}{l}\text { As análises feitas } \\
\text { mostraram a } \\
\text { dificuldade de se } \\
\text { adaptar a duas } \\
\text { doenças crônicas. As } \\
\text { crianças que já } \\
\text { tinham o diagnóstico } \\
\text { da DM1 tiveram que } \\
\text { passar por novas } \\
\text { restrições } \\
\text { alimentares com a } \\
\text { retirado do glúten } \\
\text { da sua dieta. }\end{array}$ \\
\hline $\begin{array}{l}\text { HERMES, T.S.V; VIEIRA,C.S; } \\
\text { RODRIGUES, R.M; TOSO, } \\
\text { B.R.G.O; FONSECA, L.M.M. } \\
\text { Saúde Debate Rio deJaneiro, } \\
2018\end{array}$ & $\begin{array}{l}\text { Criança diabéticado } \\
\text { tipo } 1 \text { e o convívio } \\
\text { familiar: } \\
\text { repercussões no } \\
\text { manejo da doença. }\end{array}$ & $\begin{array}{l}\text { Compreender o manejo } \\
\text { da doençapela criança e } \\
\text { sua família: como esses } \\
\text { familiares lidam com a } \\
\text { patologia. }\end{array}$ & $\begin{array}{l}\text { O diagnóstico } \\
\text { ameaça a rotina da } \\
\text { família inteira. Cada } \\
\text { família reage de uma } \\
\text { forma, dependendo } \\
\text { bastante do nível } \\
\text { social e financeiro. } \\
\text { Com base na } \\
\text { avaliação do } \\
\text { funcionamento }\end{array}$ \\
\hline
\end{tabular}




\begin{tabular}{|c|c|c|c|}
\hline & & & $\begin{array}{l}\text { familiar da criança, } \\
\text { o enfermeiro } \\
\text { decide sobre como } \\
\text { ajudar. }\end{array}$ \\
\hline $\begin{array}{l}\text { CUNHA, G.H; BARBOSA, } \\
\text { R.V.A; FONTENELE, M.S.M; } \\
\text { LIMA, M.A.C; } \\
\text { FRANCO,K.B;FECHINEL,F.V. } \\
\text { Revista Brasileira de } \\
\text { Enfermagem, } 2017 .\end{array}$ & $\begin{array}{l}\text { Resíduos de } \\
\text { insulinoterapia } \\
\text { produzidos no } \\
\text { domicílio de } \\
\text { diabéticos } \\
\text { acompanhados na } \\
\text { Atenção Primária }\end{array}$ & $\begin{array}{l}\text { Verificar com os } \\
\text { pacientes de DM1 } \\
\text { descartam os resíduos } \\
\text { perfurocortantes }\end{array}$ & $\begin{array}{l}\text { Metade dos } \\
\text { pacientes tinham } \\
\text { recebido orientações } \\
\text { e } 90 \% \text { foram } \\
\text { orientados pelo } \\
\text { enfermeiro sobre o } \\
\text { descarte correto, a } \\
\text { outra metade } \\
\text { descartava todos os } \\
\text { perfurocortantes em } \\
\text { lixos comuns e nunca } \\
\text { tinham } \\
\text { recebido orientação } \\
\text { sobre isso. }\end{array}$ \\
\hline $\begin{array}{l}\text { ORTIZ, L.O.M; DAMIÃO, } \\
\text { E.B.C; } \\
\text { ROSSATO, L.M; } \\
\text { ALVES, R.C.P. } \\
\text { Revista Eletrônica de } \\
\text { Enfermagem, } 2017\end{array}$ & $\begin{array}{l}\text { Melhores práticas de } \\
\text { enfermagem em } \\
\text { educação em } \\
\text { diabetes à criança } \\
\text { hospitalizada: uma } \\
\text { revisão integrativa }\end{array}$ & $\begin{array}{l}\text { Verificar a atuação da } \\
\text { equipe de enfermagem } \\
\text { noprocesso educacional } \\
\text { e práticas com as } \\
\text { crianças diagnosticadas } \\
\text { com DM1. }\end{array}$ & $\begin{array}{l}\text { Prover o enfermeiro } \\
\text { da educação em } \\
\text { diabetes durante a } \\
\text { hospitalização da } \\
\text { criança e no restante } \\
\text { do seu tratamento, } \\
\text { envolvendo a } \\
\text { família e todo seu } \\
\text { aspecto social. }\end{array}$ \\
\hline $\begin{array}{l}\text { BATISTA, A.F.M.B; } \\
\text { NÓBREGA, V.M; } \\
\text { GOMES, G.L.L; } \\
\text { SANTOS, M.M; } \\
\text { FERNANDES, L.T.B; } \\
\text { COLLET, N. } \\
\text { Saúde e Pesquisa,2020. }\end{array}$ & $\begin{array}{l}\text { Gestão do diabetes } \\
\text { Tipo 1: necessidades } \\
\text { de autocuidado } \\
\text { apoiado na transição } \\
\text { para adolescência }\end{array}$ & $\begin{array}{l}\text { Analisar a falha da } \\
\text { equipe de saúde no } \\
\text { manejo do autocuidado } \\
\text { em todo o seu cotidiano } \\
\text { nessa transição por que } \\
\text { as crianças passam. }\end{array}$ & $\begin{array}{l}\text { Os profissionais de } \\
\text { saúde não foram } \\
\text { eficazes ao abordar o } \\
\text { autocuidado com os } \\
\text { pré-adolescentes a } \\
\text { fim de estes se } \\
\text { tornarem } \\
\text { independentes no seu } \\
\text { tratamento. } \\
\text { Nessa fase, o } \\
\text { emocional pode } \\
\text { ficar mais abalado } \\
\text { devido às mudanças } \\
\text { próprias da idade, e } \\
\text { a faltade cuidado da } \\
\text { enfermagem gera } \\
\text { ainda mais } \\
\text { dificuldades na } \\
\text { prevenção de } \\
\text { complicações. }\end{array}$ \\
\hline
\end{tabular}




\begin{tabular}{|c|c|c|c|}
\hline $\begin{array}{l}\text { ROSSANEIS, A.M; } \\
\text { ANDRADE, S.M; } \\
\text { GVOZD, R; }\end{array}$ & $\begin{array}{l}\text { Fatores associados } \\
\text { ao controleglicêmico }\end{array}$ & $\begin{array}{l}\text { Investigar como } \\
\text { são os fatores } \\
\text { glicêmicos dos }\end{array}$ & $\begin{array}{l}\text { Indivíduos com } \\
\text { outros tipos de } \\
\text { problemas, como }\end{array}$ \\
\hline $\begin{array}{l}\text { PISSINATI, P.S.C;HADDAD, } \\
\text { M.C.L. } \\
\text { Ciência \& Saúde } \\
\text { Coletiva, } 2019\end{array}$ & $\begin{array}{l}\text { de pessoas com } \\
\text { diabetes mellitus }\end{array}$ & $\begin{array}{l}\text { pacientes com diabetes } \\
\text { mellitus esuas } \\
\text { variações }\end{array}$ & $\begin{array}{l}\text { obesidade, } \\
\text { apresentavam índices } \\
\text { de hemoglobina } \\
\text { glicada mais altos. A } \\
\text { conclusão é de que o } \\
\text { enfermeiro precisa } \\
\text { dar maior atenção } \\
\text { para esses pacientes } \\
\text { pelo riscode maiores } \\
\text { complicações. }\end{array}$ \\
\hline $\begin{array}{l}\text { SANTOS, A.L; MARCON,S.S; } \\
\text { TESTON, E.F; BACK, I R;LINO, } \\
\text { I.G.T; BATISTA, V.C; } \\
\text { MATSUDA, L.M; } \\
\text { HADDAD, M.C.F.L. } \\
\text { Revista Min Enfermagem, } \\
2020\end{array}$ & $\begin{array}{l}\text { Adesão ao } \\
\text { tratamento de } \\
\text { diabetes mellitus e } \\
\text { relação com a } \\
\text { assistência na } \\
\text { atenção primária }\end{array}$ & $\begin{array}{l}\text { Analisar como o } \\
\text { tratamento } \\
\text { medicamentoso e o não } \\
\text { medicamentoso agem } \\
\text { com a assistência na } \\
\text { atenção primária }\end{array}$ & $\begin{array}{l}\text { O resultado foi } \\
\text { positivo em relação } \\
\text { ao tratamento } \\
\text { medicamentoso e à } \\
\text { atenção do } \\
\text { enfermeiro no } \\
\text { atendimento } \\
\text { primário, mas a } \\
\text { adesão a medidas } \\
\text { não farmacológicas } \\
\text { foi mais baixa. Assim, } \\
\text { o estudo reforça que } \\
\text { o enfermeiro precisa } \\
\text { estimular mais seus } \\
\text { pacientes, visando ao } \\
\text { tratamento do } \\
\text { diabetes com } \\
\text { medidas não } \\
\text { medicamentosas e } \\
\text { mudanças no estilode } \\
\text { vida para a melhoria } \\
\text { na qualidade de vida } \\
\text { destes. }\end{array}$ \\
\hline
\end{tabular}




\begin{tabular}{|c|c|c|c|}
\hline $\begin{array}{l}\text { OKIDO, A.C.C; } \\
\text { ALMEIDA. A; VIEIRA, } \\
\text { M.M; NEVES, E.T; } \\
\text { MELLO, D.F; LIMA } \\
\text { R.A.G. } \\
\text { Escola Anna Nery, } 2017\end{array}$ & $\begin{array}{l}\text { As demandas de } \\
\text { cuidado das crianças } \\
\text { com diabetes } \\
\text { mellitustipo } 1\end{array}$ & $\begin{array}{l}\text { Conhecer relatos e } \\
\text { experiências de } \\
\text { familiares acerca dos } \\
\text { cuidados relacionado } \\
\text { à qualidade de vida } \\
\text { das crianças } \\
\text { portadoras de DM1. }\end{array}$ & $\begin{array}{l}\text { Apresentou a } \\
\text { experiência das } \\
\text { famílias com base } \\
\text { em seu contexto } \\
\text { social. } \\
\text { Participaram do } \\
\text { estudo dez crianças. } \\
\text { O tempo para } \\
\text { descoberta do } \\
\text { diagnóstico variou } \\
\text { de dois a seis anos. } \\
\text { A insulinoterapia mais } \\
\text { utilizada foi } \\
\text { associação de NPH e } \\
\text { regular, com } \\
\text { intercorrências de } \\
\text { hiperglicemia e } \\
\text { hipoglicemia na }\end{array}$ \\
\hline & & & maioria dos casos. \\
\hline $\begin{array}{l}\text { MENEZES, M; Leo } \\
\text { LACERDA, } \\
\text { L.L.V;BORELLA, J; } \\
\text { ALVES, T.P. } \\
\text { Psicologia: Teoria e } \\
\text { Pesquisa, } 2019\end{array}$ & $\begin{array}{l}\text { Qualidade de vida e } \\
\text { diabetes mellitus: } \\
\text { atopercepção de } \\
\text { adolescentes de uma } \\
\text { cidade do sul do } \\
\text { Brasil. }\end{array}$ & $\begin{array}{l}\text { Avaliar a qualidade } \\
\text { de vida de } \\
\text { adolescentes com } \\
\text { DM1 como } \\
\text { pacientes na } \\
\text { atenção primária. }\end{array}$ & $\begin{array}{l}\text { Os resultados obtidos } \\
\text { indicaram que os } \\
\text { adolescentes da } \\
\text { amostra } \\
\text { apresentaram uma } \\
\text { boa visão de QVRS.O } \\
\text { único ponto negativo } \\
\text { foi a prática de } \\
\text { atividade física, que é } \\
\text { negligenciada pelos } \\
\text { jovens }\end{array}$ \\
\hline $\begin{array}{l}\text { CRUZ, D.S.M; COLLET,N; } \\
\text { NÓBREGA, V. } \\
\text { Ciência \& Saúde } \\
\text { Coletiva, } 2018 .\end{array}$ & $\begin{array}{l}\text { Qualidade de vida } \\
\text { relacionada à } \\
\text { saúde de } \\
\text { adolescentes com } \\
\text { DM1 - revisão } \\
\text { integrativa. }\end{array}$ & $\begin{array}{l}\text { Avaliar aQVRS } \\
\text { de } \\
\text { adolescentes } \\
\text { portadores da } \\
\text { DM1. }\end{array}$ & $\begin{array}{l}\text { O estudo ressaltou } \\
\text { que o tema QVRS de } \\
\text { adolescentes tem } \\
\text { sido pesquisado com } \\
\text { frequência } \\
\text { internacionalmente, } \\
\text { porém, no Brasil, não } \\
\text { se tem dado a devida } \\
\text { importância ao } \\
\text { assunto. } \\
\text { Concluiu que a ajuda } \\
\text { dos pais e dos } \\
\text { profissionais desaúde } \\
\text { ameniza o medo que } \\
\text { a doençacausa nos } \\
\text { adolescentes de ter } \\
\text { uma hipoglicemia, e } \\
\text { a ansiedade } \\
\text { interfere nos índices } \\
\text { metabólicos. }\end{array}$ \\
\hline
\end{tabular}




\begin{tabular}{|l|l|l|l|}
\hline $\begin{array}{l}\text { PEREIRA, M. F. V; } \\
\text { FIGUEIREDO, A. M. } \\
\text { SALUSVITA, 2017 }\end{array}$ & $\begin{array}{l}\text { A importância do } \\
\text { diagnóstico da } \\
\text { diabetes } \\
\text { mellitus tipos } \\
1 \text { e 2 na infância. }\end{array}$ & $\begin{array}{l}\text { Fazer uma revisão } \\
\text { de literatura acerca } \\
\text { da prevenção e dos } \\
\text { fatores de risco da } \\
\text { DM1. }\end{array}$ & $\begin{array}{l}\text { Os primeiros sinaise } \\
\text { sintomas precisam } \\
\text { ser devidamente } \\
\text { observados para que } \\
\text { os controles } \\
\text { alimentares e } \\
\text { atividades físicas } \\
\text { sejam monitorados } \\
\text { pelos pais para não } \\
\text { haver alguma } \\
\text { complicação. }\end{array}$ \\
\hline
\end{tabular}

Fonte: As autoras, 2020

Com relação ao ano de publicação dos estudos selecionados, oito artigos (40\%) são do ano de 2017, quatro (20\%) de 2018, três (15\%) de 2016, três (15\%) de 2019 e duas publicações (10\%) são de 2020.

No que tange aos periódicos nos quais os artigos científicos selecionados foram publicados, pode-se verificar que a Escola Anna Nery se destacou, com quatro (20\%) publicações, seguida por Revista Brasileira de Enfermagem; Revista Escola de Enfermagem da USP e Revista Ciência \& Saúde Coletiva, com dois artigos (10\%) cada; Psicologia - Teoria e Pesquisa, Saúde e Pesquisa, Revista Eletrônica de Enfermagem, Saúde Debate Rio de Janeiro, Revista Gaúcha de Enfermagem, Acta Paul Enfermagem, Revista Min Enfermagem, Revista Latino-Americana de Enfermagem, Texto e Contexto Enfermagem, SALUSVITA com um artigo cada (5\%).

Quanto ao conteúdo dos artigos, evidenciou-se que o conhecimento produzido congregou temas principais, como qualidade de vida das crianças com DM1, vivência das mães e familiares que lidam com a doença, autocuidado das crianças e ações do enfermeiro mediante a patologia e orientações.

\subsection{O DIABETES MELLITUS: CONCEITO, DIAGNÓSTICO E TRATAMENTO}

A Sociedade Brasileira de Diabetes (2020) e Cunha et al. (2017) afirmam que a Diabetes Mellitus (DM) é caracterizada como um distúrbio metabólico, baseado em hiperglicemia persistente, tendo como deficiência a produção de insulina ou a ação dela, ou até mesmo ambos os mecanismos. A hiperglicemia se associa a complicações crônicas micro e macrovasculares, aumento de morbidade, redução da qualidade de vida e alto índice de mortalidade. Os fatores responsáveis pelos principais tipos de DM são: genéticos, biológicos e ambientais. Existem três tipos de diabetes mellitus: Diabetes Mellitus Gestacional (DMG), Diabetes Mellitus tipo 2 (DM2) e Diabetes Mellitus tipo 1 (DM1). Mundialmente, cerca de 425 milhões de pessoas vivem com DM. 
Pereira e Figueiredo (2017) ressaltam que a DM é um importante e progressivo problema de saúde em nível mundial, sendo indiferente se o país é mais desenvolvido ou menos. Essa doença está inclusa no grupo de enfermidades crônicas que se responsabilizam por $60 \%$ de todo o peso resultante de doenças no mundo todo, tornando-se uma grande dificuldade na saúde mundial e representando 72\% das causas de morte. O DM no Brasil acomete aproximadamente 10\% da população entre 30 e 69 anos, cerca de 9 a 10 milhões de pessoas, destas, 5 a 6 milhões já foram diagnosticadas, o que é considerado um índice baixo de diagnóstico.

O DMG ocorre por causa de uma intolerância a carboidratos de gravidade variante, tendo início ou sendo diagnosticado durante a gestação. O DMG oferece riscos para mãe, feto e neonato, podendo ser diagnosticado geralmente no segundo ou terceiro trimestre da gestação. O DMG pode durar ou persistir após o parto, sendo assim, é um grande fator de risco para o desenvolvimento da DM2. Alguns fatores de risco para a DMG são: idade materna avançada, sobrepeso, obesidade ou ganho excessivo de peso na gravidez, história familiar de diabetes em parentes de primeiro grau, hipertensão ou préeclâmpsia na gestação, entre outros. Dependendo da população estudada e do critério diagnosticado, cerca de 1 a $14 \%$ podem ter DMG (SBD, 2020).

O DM2 equivale de $90 \%$ a 95\% de todos os casos de DM. Geralmente o DM2 acomete mais indivíduos que estão passando da fase adulta para a terceira idade, porém, em alguns países, já há um índice alto de DM2 em crianças e adolescentes. É uma doença com forte fator genético, mas também decorrente de fatores ambientais. Hábitos como inatividade física, alimentação inadequada favorecem a ocorrência de obesidade, destacando-se como principais fatores de risco. Geralmente o DM2 é uma doença assintomática e seu diagnóstico é realizado em laboratórios de rotina ou em manifestações de complicações. Os principais sintomas do DM2 são: poliúria, polidipsia, polifagia e emagrecimento inexplicável. Em $80 \%$ a 90\% dos casos, o DM2 está associado ao excesso de peso e a outros componentes metabólicos (SBD, 2020; ROSSANEIS et al., 2019).

A SBD (2020) e Pereira e Figueiredo (2017) afirmam que a DM1 é uma doença autoimune, poligênica, sendo causada pela destruição das células beta do pâncreas e, por conta disso, ocasiona deficiência completa na produção de insulina. De acordo com a Internacional Diabetes Federation, cerca de 88 mil brasileiros possuem a DM1, ocupando o terceiro lugar em prevalência da doença no mundo. Mesmo com a prevalência de DM1 aumentada, este tipo corresponde a apenas $5 \%$ a 10\% de todos os casos de DM. É o tipo de diabetes que se encontra mais em crianças e jovens entre a faixa etária dos 10 aos 14 anos, não descartando a possibilidade de, em alguns casos, estar presente em adultos 
também, porém sua prevalência é mais comum na infância, com aproximadamente 1.500 pessoas com DM1 aos 12 anos de idade.

Conforme a SBD (2020), a DM1 ainda pode ser classificada em dois tipos, A e B. O tipo A é quando é criada uma deficiência de insulina por autodestruição das células $\beta$, e o tipo B é a deficiência de insulina sem uma causa comprovada.

O DM1 tem seu início, principalmente, na infância e adolescência, e exige uma rotina de tratamento que requer muita atenção e cuidado (BRANCAGLIONI et al., 2016). Essa enfermidade se associa a complicações em longo prazo, afetando a qualidade de vida e ainda tendo um índice alto de morbimortalidade (WOLKERS et al., 2017).

O diagnóstico da DM na infância se pauta nos mesmos requisitos utilizados para o diagnóstico em outras idades. Quase todos os clientes são diagnosticados com sintomas associados a glicemia >200 $\mathrm{mg} / \mathrm{dL}$. Em outros casos, pode-se detectar a partir de glicemia de jejum $\geq 126 \mathrm{mg} / \mathrm{dL}$, em dois momentos. Em crianças, é menos comum a solicitação d e teste de tolerância à glicose oral (TTGO), porém, se necessário, a dose que deve ser administrada à criança é de $1,75 \mathrm{~g} / \mathrm{kg}$, sendo o máximo de 75g. Às vezes, os sintomas de poliúria (aumento da produção de urina) e polidipsia (ingestão excessiva de água por dia) e perda de peso não são percebidos pelos responsáveis e profissionais da saúde (PEREIRA; FIGUEIREDO, 2017; SBD, 2020).

Os sintomas não percebidos a tempo fazem com que a criança chegue à avaliação em estado avançado de descompensação metabólica, em vários estágios de cetoacidose, desidratação grave, acidose e até mesmo em coma. A hipoglicemia é a complicação aguda que mais ocorre em pacientes com DM1, que é uma queda significativa na taxa de açúcar no sangue. Quando isso ocorre, podem surgir sintomas como: palidez, confusão mental, desmaio, baixa coordenação motora, fraqueza e dor de cabeça (PEREIRA; FIGUEIREDO, 2017; SBD, 2020).

O Protocolo de Atenção à Saúde (2012) cita a metodologia do tratamento, que tem como objetivo deixar o índice de HbA1c mais baixo para que sejam evitadas as complicações agudas e crônicas, ou seja, desenvolvimento de cegueira, necessidade de amputação de membros inferiores, infarto agudo do miocárdio (IAM) e acidente vascular cerebral (AVC). Estas também possuem como fatores de risco a obesidade, hiperglicemia e resistência à insulina.

O risco de um cliente com DM adquirir doenças crônicas é bem superior ao de pessoas que não possuem a patologia, sendo comum que clientes com DM tenham complicações como nefropatia e 
retinopatia. Em clientes com DM, patologias como doença coronariana, cerebrovascular e arterial periférica tornam-se mais graves e são tidas como principal causa de morbimortalidade. Em comparação a indivíduos que não são portadores de DM, os diabéticos possuem risco de adquirir cegueira 30 vezes maior, 40 vezes para amputações de membros inferiores, duas a cinco vezes para um infarto agudo do miocárdio (IAM) e têm duas a três vezes mais chance de sofrer um acidente vascular cerebral (AVC). Fatores como obesidade, hiperglicemia e resistência à ação da insulina cooperam para que o cliente venha a ter essas doenças de risco (PAS, 2012).

De acordo com PAS (2012), a cetoacidose é uma complicação grave, seu foco é a falta parcial ou completa de insulina, tendo índice de mortalidade próximo a 5\%. É mais comum ocorrer em pessoas com DM1 e é apontada como o primeiro sintoma da doença.

O paciente com DM também tem como fator de risco a manifestação de complicações agudas que requerem socorro imediato, uma vez que, em determinadas situações, o indivíduo corre risco de vida. A hipoglicemia é outra complicação para cujos sintomas os portadores de DM devem estar sempre atentos, tais como tremores, visão turva, ocasionando desmaios. Isso ocorre quando a glicemia fica abaixo de 60mg/dL (PAS, 2012).

O oposto à hipoglicemia, denominado hiperglicemia, quando a glicemia está acima de $250 \mathrm{mg} / \mathrm{dL}$ também requer bastante cuidado e é necessário aplicação imediata de insulina. Quando a glicose alcança um índice muito elevado, chegando a $800 \mathrm{mg} / \mathrm{dL}$, e o paciente entra em estado de confusão mental, além de outros sintomas, trata-se de síndrome hiperosmolar não ciótica, que acontece apenas na DM2 e normalmente em pacientes mais idosos, nos quais se eleva o grau de mortalidade (PAS, 2018).

Segundo a SDB (2020), o tratamento são as três medidas protocoladas: insulinoterapia, dieta alimentar e prática de atividade física, que devem ser administradas imediatamente após o diagnóstico, especialmente a insulina, caso o paciente esteja hospitalizado.

Cunha et al. (2017) apontam que tratamento para o DM acontece por meio de medidas farmacológicas e não farmacológicas, tendo como principal objetivo conciliar as duas medidas para que controlem os níveis de glicemia. Assim, o cliente continuará assintomático e evitando complicações agudas, proporcionando uma boa qualidade de vida a fim de reduzir a mortalidade.

A medida farmacológica mais utilizada é a insulinoterapia, uma fonte que produz resíduos, constituída por agulhas, lancetas, algodão, seringas e fitas reagentes. O cliente com DM1 pode fazer uso de 
insulina mais de uma vez ao dia, dependendo do caso, e pode averiguar a glicemia capilar. É sempre importante lembrar que tanto o cliente quanto o seu familiar devem ser orientados sobre a administração da insulina e o descarte dos resíduos (CUNHA et al., 2017; PAS, 2012). A glicemia capilar deve ser monitorada pelo menos três vezes ao dia metodicamente, antes do almoço, antes do jantar e ao deitar e, consequentemente, devem ser feitas as aplicações de insulina após o resultado da monitorização.

O Protocolo de Atenção à Saúde (2012) diz que o tratamento não farmacológico é de grande importância no cuidado dessas doenças, evitando-se diversos fatores de risco que se associam a DM. Clientes com DM necessitam de um acompanhamento específico, realizado por nutricionista que entenda do assunto e que seja bastante experiente. Ele irá explicar ao cliente sobre a quantidade adequada de carboidratos na alimentação, além de ensinar a medir e estimar o tamanho das porções. As pessoas que possuem diabetes, mesmo que realizem a contagem de carboidratos, devem evitar fazer uso de bebidas açucaradas e alimentos. Se o indivíduo seguir as orientações profissionais, evitará riscos de doenças cardiovasculares e esteatose hepática (SBD, 2020).

De acordo com o Protocolo de Atenção à Saúde (2012) e Kaneto et al. (2018), medidas não farmacológicas, como desenvolver atividade educativas por meio de contações de histórias, quebracabeças, jogos de memória relacionados a DM, auxiliam no tratamento. Tanto para crianças quanto para adultos a prática de atividades físicas, associada a uma alimentação saudável, é essencial ao tratamento, buscando a manutenção do peso.

No que tange à faixa etária da primeira infância, a SBD (2020) destaca a importância da monitorização da glicemia, que seja feita pelo menos quatro vezes por dia, para que a correção com a insulina possa ser feita mais rapidamente se estiver alterada, evitando assim hiper ou hipoglicemia. Esse processo facilita um melhor ajuste ao tratamento.

\subsection{A CRIANÇA E O DIABETES MELLITUS}

Para a criança, o entendimento das mudanças de hábitos que a presença da patologia trará para seu cotidiano é bastante complexo. Ela ainda não consegue assimilar com exatidão o porquê dessas mudanças, só consegue enxergá-las como algo ruim, que traz medo e insegurança. No entanto, o apoio de quem ela mais ama, que são a família e os amigos, pode torná-la mais confiante. A escola, os amigos ajudam bastante no processo de melhora da autoestima, que afeta diretamente o controle da diabetes (PENAFORT et al., 2016). 
A família é muito importante durante o processo pós-diagnóstico da criança, visto que a descoberta da doença é um sofrimento muito grande para ambas as partes. A criança ainda não tem compreensão a respeito da sua condição de saúde, e as formas de cuidado podem afetá-la muito, gerando raiva, tristeza, angústia por ainda não entender a respeito da sua doença e da necessidade de cuidados a partir do diagnóstico, como restrições alimentares, insulinoterapia e monitorização glicêmica (HERMES et al., 2018).

Segundo Wolkers et al. (2017), na transição da infância para adolescência, a descoberta de uma doença crônica pode ser um período de risco em relação ao tratamento, pois este requer aceitação da enfermidade, visto que, além do autocuidado, também é preciso cuidado com a família, uma vez que o diagnóstico afeta todos os envolvidos. Durante essa fase, existem fatores de desequilíbrio no manejo do tratamento, como o esquecimento de administrar ou até mesmo erro na dosagem da insulina, também se pode citar a falta de exercícios físicos e o desconhecimento de alimentos nutritivos. Com isso, acaba ocorrendo o baixo controle dos níveis glicêmicos, o que acarreta episódios de hiperglicemia e/ou hipoglicemia.

Práticas educativas ajudam bastante a criança no autocuidado, facilitando a compreensão e a aceitação dessa nova rotina. Essas práticas são realizadas por meio de brincadeiras motivacionais que fazem com que a criança aprenda a lidar com a doença, melhorando sua qualidade de vida (KANETO et al., 2018; VENANCIO; BANCA; RIBEIRO, 2017).

De acordo com o estudo de Ortiz et al. (2017), a equipe multiprofissional de saúde deve ajudar a família e a criança no processo de educação em saúde. Esse processo tem como finalidade diminuir a ansiedade, o medo e o estresse, proporcionando um melhor conhecimento para o cuidado. Após a descoberta das doenças, é fundamental a família estar presente e auxiliar a criança no manejo do autocuidado. Além disso, o processo de educação em saúde cria um vínculo entre a família e a equipe de saúde, fazendo com a criança sinta confiança nos profissionais e familiares.

Ortiz et al. (2017) relatam que é importante que a criança seja encorajada a ter o manejo na aplicação de insulina, assim ela irá se orgulhar de seu autocuidado. A equipe multiprofissional deve prezar pelo conhecimento, a fim de estar sempre proporcionando qualidade de vida e efetividade no processo de educação em saúde da criança, estando disponível para fornecer informações para a família e o cliente.

A equipe multiprofissional em saúde, incluindo o enfermeiro, a fim de ajudar os familiares e a criança com DM, estabelece um plano de cuidados que comprende cinco etapas: avaliação, identificação, 
conhecimento, comportamento, vida-social/histórico de saúde e aconselhamento (BATISTA et al., 2020).

Wolkers et al. (2017) destacam a importância da vacinação dessas crianças, vista como um fator primordial em suas vidas. Com a caderneta de vacinação em dia, a criança fica livre de certas doenças que, junto com DM1, podem debilitar ainda mais sua saúde. Crianças portadoras de doenças crônicas, incluindo a DM1, possuem direito às vacinas do Programa Nacional de Imunização (PNI), que é disponibilizado para todos os brasileiros, e aos imunobiológicos especiais, que estão disponíveis nos Centros de Referência de Imunobiológicos Especiais (Cries).

A criança portadora de doença crônica vive em constantes variações por ser de grupo de risco vulnerável para outras doenças. Obtém estabilidade se for dada atenção especial ao tratamento, porém a instabilidade pode ocorrer. Nesse sentido, toda prevenção contra outras doenças é essencial, particularmente a mudança no estilo de vida (WOLKERS, 2019).

Os familiares das crianças com DM1, além de enfrentar a nova rotina, eles ainda precisam manter os níveis sanguíneos adequados de glicose da criança, a fim de prevenir complicações e dar continuidade ao tratamento, adquirindo conhecimento e manejo da doença (WOLKERS et al., 2017; CRUZ et al., 2017).

\subsection{ATUAÇÃO DO ENFERMEIRO DA ATENÇÃO PRIMÁRIA NA ASSISTÊNCIA À CRIANÇA COM DM1 VISANDO À QUALIDADE DE VIDA}

A Atenção Primária à Saúde (APS) é a porta de entrada para os cuidados aos pacientes portadores de doenças crônicas. É o local ao qual eles terão acesso com

mais facilidade por ser próximo à sua moradia. Os profissionais farão um planejamento de cuidados para o controle da doença (SANTOS et al., 2020).

Ademais, a instituição de APS tem como princípio trabalhar em conjunto com uma equipe multidisciplinar, contando com profissionais como enfermeiro, técnico de enfermagem, agente de saúde, nutricionista, psicólogo, médico, que irão implementar um tratamento para obter um melhor resultado do controle da patologia (SANTOS et al.,2020).

Na APS, o profissional que mais lida com o paciente é o enfermeiro, por conseguinte, com o tempo, vai-se criando um vínculo entre eles, que proporciona maior confiança e também resulta em segurança para o tratamento, motivo pelo qual a APS é tão valorizada pelos pacientes. Devido às suas condições 
de acesso, ela é capaz de resolver situações de forma mais rápida e eficaz, apesar de ser identificada por cuidados básicos, ou seja, que exijam poucos recursos tecnológicos. O enfermeiro na APS identifica os fatores de risco no suporte de decisão com toda atenção voltada aos portadores de doenças crônicas (SANTOS et al., 2020; WOLKERS, 2019; BRASIL, 2018).

A consulta de enfermagem na APS é determinante quando se trata de diabetes mellitus. A busca ativa pelos pacientes tem como objetivo melhorar a sua qualidade de vida, efetuando estratégias de tratamento baseadas no nível social de cada um, de autocuidado e de prevenção de complicações crônicas. Por essa razão, a American Diabetes Association (ADA) recomenda apoio, orientação e cuidado aos portadores para melhoria do seu bem-estar (ROSANEISS et al.,2017).

De acordo com o Coren SC (2017), a Sistematização da Assistência de Enfermagem (SAE) objetiva a melhora no atendimento de populações que necessitam de saúde pública. A SAE estabelece a organização no processo de trabalho do enfermeiro, de forma que as atividades são realizadas por etapas. Ela é um instrumento metodológico que auxilia o profissional de enfermagem no cuidado, fortalecendo a importância da equipe de enfermagem na atenção ao cliente.

A Resolução do Cofen 358/2009 determina que o enfermeiro zele pela organização em busca de estar sempre preparado para realizar seu trabalho a partir da Sistematização de Assistência de Enfermagem (SAE). A SAE, juntamente com diretrizes, normativas e orientações, possibilita o manejo do processo de enfermagem. Tem como finalidade orientar o profissional de enfermagem sobre o cuidado na prática, mostrando o quão importante é o cuidado da enfermagem na vida da população (COREN, 2017).

A SAE disponibiliza uma ferramenta que é o Processo de Enfermagem (PE), que é privativo do enfermeiro e é composto de cinco etapas: histórico de enfermagem, diagnóstico de enfermagem, planejamento de enfermagem, implementação e avaliação de enfermagem. O enfermeiro na APS, utilizando-se do PE durante a consulta de enfermagem, pode solicitar alguns exames laboratoriais para acompanhar o andamento do controle da doença, como exames de glicemia em jejum, creatina sérica, exames de urina e HbA1C (glicose glicada). Além disso, pode verificar as dificuldades que a criança e família desta possam estar enfrentando no manejo da doença para oferecer-Ihes educação em saúde (COREN, 2017). Collet et al. (2018) salientam que o autocuidado é muito importante na vida de um cliente com DM, tornando-se uma ação de extrema responsabilidade e atenção do enfermeiro junto com a população. 
Não é fácil para a família receber a notícia de que a criança é portadora de DM1, porém, quando a mesma acolhe a criança, oferecendo-lhe suporte por meio da educação, juntas encaram a doença e assim a criança vai aumentando seu conhecimento e adquirindo autocuidado, estando ciente da importância do tratamento para a doença (PENNAFORT et al.,2016).

É de extrema relevância que a equipe de saúde acolha essa família e que esteja partilhando das mesmas questões sobre o tratamento. Nesse contexto, o enfermeiro é o educador, oferecendo planejamento de cuidados e orientações por meio dos quais a família consiga dar atendimento à criança dentro dos objetivos propostos (ORTIZ et al., 2017).

Diferentemente do atendimento a um adulto para passar orientações sobre os cuidados, a DM1 traz um desafio ao enfermeiro, que é conduzir uma criança em um autocuidado tão complexo. Nesse sentido, esse profissional pode aplicar algumas táticas para amenizar as dificuldades impostas pela doença (CRUZ et al.,2016).

O enfermeiro que se propõe a ajudar essa criança a ter autonomia no seu cuidar na rede de APS pode construir maneiras de melhorar a qualidade de vida e entendimento de autocuidado para esses pacientes. Assim como já existem rodas de conversas para portadores de doenças crônicas nas Unidades Básicas de Saúde (UBSs), podem promover minicursos, debates infantis de forma lúdica e divertida, a fim de que as crianças aprendam mais sobre a DM1 e não a vejam como um fantasma que as assombra (CRUZ et al., 2016).

O enfermeiro tem a possibilidade de proporcionar a essa criança o seu próprio cuidado. Logo após o diagnóstico, as mães normalmente tomam para si o cuidado medicamentoso e não farmacológico de seus filhos, principalmente se forem bem pequenos. Porém, assim que a criança for se acostumando com a sua doença e a entendendo melhor, ela pode adquirir independência no seu tratamento, seguindo toda a orientação do enfermeiro que, nesse processo, é quem irá guiar a sua autossuficiência (COLLET et al., 2018).

Ter um bom conhecimento, procedente da orientação de enfermagem, saber manejar as técnicas, possuindo um controle eficaz para o DM1 na infância, envolve vários fatores, como aceitação da própria criança e a busca dos familiares por ajuda dos profissionais da saúde para equilíbrio biológico, psíquico e social. Todos esses fatores contribuirão para favorecer boas estratégias para o cuidado da criança com DM1 (HERMES et al., 2018). 
Uma outra forma é acompanhamento mensal na Unidade Básica de Saúde (UBS) para checagem glicêmica e contagem de carboidratos de acordo com as orientações recebidas, controle de peso e estatura por 12 meses a partir do início do tratamento (CRUZ et al., 2016). O enfermeiro deve estimular a família da criança com DM1 a fazer uma terapia psicológica para ajudar a criança na aceitação da doença e do tratamento, além de procurar apoio nutricional para orientação devida, segundo a SBD (2020), que aponta a importância de se estabelecer um plano alimentar e a contagem de carboidratos, fazendo correção com a insulina junto com o monitoramento, o que traz um resultado bem efetivo para o crescimento do paciente.

O apoio emocional faz o tratamento ser mais eficaz e mais estabilizado. As crianças nunca esperam que terão que passar por todo esse processo de uma patologia que não tem cura e que necessitarão de cuidados para o resto da vida. O enfermeiro precisa estar atento à estrutura familiar dessa criança e, com base nela, ajudar os responsáveis pela criança a tornarem o ambiente mais estável para que ela possa viver com mais segurança (MENEZES, 2018).

Cabe ressaltar que o transtorno e o incômodo das aplicações doloridas, das restrições alimentares são muito sofridos para as crianças e demora um tempo para que elas adquiram maturidade de assimilar o porquê dessas privações. O enfermeiro pode auxiliá-las a cada consulta de enfermagem, buscando o entendimento delas acerca desse processo, com a finalidade que até façam suas próprias restrições no seu autocuidado (MENEZES, 2018).

Além disso, a SBD (2020) destaca que a atividade física é fundamental, pois contribui para a redução dos níveis glicêmicos. Porém, deve ser praticada com uma preparação com a ingesta de carboidratos e administração da insulina antes, que pode ser feita com dosagem menor. Se a atividade é realizada por mais tempo, faz-se necessário consumir algum alimento para evitar a ocorrência de hipoglicemia. No entanto a monitorização glicêmica precisa ser feita horas depois dado o risco de hipoglicemia por mais tempo.

Os resultados do estudo de Menezes et al. (2019) apontaram que a prática de atividades físicas não é muito procurada como tratamento auxiliar para DM1, por isso deve ser reforçada sua importância no momento de orientação profissional, pois essas atividades são fundamentais para para manutenção dos níveis de glicose mais baixos. Além da prática de atividades físicas, devem-se recomendar restrições alimentares, devidamente acompanhadas por um nutricionista, monitorização frequente de glicose e aplicações diárias de insulina. 
Cabe salientar que, na linha de cuidados secundários do DM na rede de atenção à saúde, a APS conta com o Departamento de Saúde da Criança e do Adolescente, que possui uma equipe multiprofissional e outros recursos que não são da competência da APS. É feita uma triagem dos pacientes cadastrados no programa para acompanhar a necessidade de cada um, segundo a linha de tratamento e de profissionais que irão conduzir os cuidados. Os métodos não farmacológicos e a educação em saúde são as principais estratégias do enfermeiro na assistência à criança com DM1 na APS.

\section{CONSIDERAÇÕES FINAIS}

Ao fazer a pesquisa dos artigos com foco na criança com diabetes mellitus Tipo 1, percebeu-se a importância dos aspectos de tratamento, cuidado e planejamento do enfermeiro. A DM1 é uma doença muito grave e envolve questões familiares, financeiras, além do fato de seus portadores principais serem crianças. Existe uma dificuldade grande de reconhecimento dos primeiros sintomas. Os pais raramente pensam que os filhos, tão jovens, podem adquirir uma doença crônica nessa idade.

O mais significante na pesquisa é constatar que o enfermeiro tem um papel determinante no atendimento dessas crianças e de suas famílias e um campo bastante amplo de orientação, que pode fazer toda a diferença no tratamento desses pacientes.

O suporte profissional que o enfermeiro emprega mais exclusivamente na Atenção Primária à Saúde reside na confiança estabelecida pelo vínculo entre criança e enfermeiro, resultando em um planejamento do cuidado mais eficaz. Isso se dá uma vez que o paciente consegue entender melhor seu tratamento, é bem capacitado para saber realizar o seu próprio autocuidado, devido à excelente orientação que lhe foi prestada, o que ocasiona a melhora na qualidade de vida.

O diagnóstico de DM1 na infância não é uma sentença tão negativa, tem sim seus impasses, as adversidades do tratamento, a forma incômoda da doença e os medos, mas é possível ter uma boa qualidade de vida com o acolhimento do enfermeiro e da equipe de saúde, com os métodos terapêuticos e acompanhamentos corretos. O paciente tem o prognóstico para ter uma vida longa e saudável, sem que tenha que se submeter a grandes intervenções no decorrer da vida.

Demonstra-se uma atenção para o incentivo do autocuidado da própria criança, em que o enfermeiro atua bastante no ensino e orientação para que esse paciente possa ter autonomia com a devida cautela, dependendo da idade em que o paciente foi acometido pela doença.

Nesta investigação, constatou-se a escassez de estudos relacionados ao tema. É notório que o assunto não é muito abordado em publicações, principalmente na área da enfermagem. É certo que nem todos 
os profissionais de enfermagem compreendem a importância que têm no tratamento de pacientes Diabéticos Tipo 1. Nesse sentido, é fundamental que busquem protagonizar o atendimento de pessoas com essa patologia, pois muitos acreditam que esses cuidados envolvem somente os profissionais médicos. Destaca-se a importância da atenção primária, onde os enfermeiros têm mais vínculo com os familiares e com a criança, tornando-se, assim, o planejamento de enfermagem mais bem implantado e resolutivo.

Atingiu-se o objetivo da pesquisa, apresentando os pontos em que a qualidade de vida dessas crianças pode ser melhorada, com o amparo da da enfermagem, especificamente dentro da atenção primária. 


\section{REFERÊNCIAS}

Atlas IDF 2017 - Diabetes no brasil - Número de pessoas com diabetes no mundo e por região em 2017 e em 2045 (20-79 anos). Disponível em:

https://www.diabetes.org.br/profissionais/images/2018/poster-atlas-idf-2017.pdf.Acesso: 27 de setembro de 2020.

BRANCAGLIONI, B.C.A.; RODRIGUES, G.C.; DAMIÃO, E.B.C.; QUEIROZ, M.S.;

NERY, M. Crianças e adolescentes que convivem com diabetes e doença celíaca. Revista Gaúcha de Enfermagem, Porto Alegre, v.37, n.1, mar. 2016.

Disponívelem:<https://www.scielo.br/scielo.php?script=sci_arttext\&pid=S198314472016000100411 \&lng=pt\&tlng=pt>. Acesso em: 14 de outubro de 2020.

BRASILIA, 15 out. 2009. Resolução COFEN 358/2009. Disponível em:

http://www.cofen.gov.br/resoluo-cofen-3582009_4384.html. Acesso em: 30 de outubro de 2020.

BATISTA, A.F.M.; NÓBREGA, V.M.; GOMES, G.L.L.; SANTOS, M.M.;

FERNANDES, L.T.B.; COLLET, N. Gestão do diabetes tipo: necessidades de autocuidado apoiado na transição para adolescência. Saúde e Pesquisa, Maringá, v.13, n.2, p.363-375, abr./jun. 2020. Disponível em:

<https://periodicos.unicesumar.edu.br/index.php/saudpesq/article/view/7523/6287>. Acesso em: 19 de outubro de 2020.

COLLET, N.; BATISTA, A.F.M.B.; NÓBREGA, V.M.; SOUZA, M.H.N.; FERNANDES,

L.T.B. Autocuidado apoiado no manejo da diabetes tipo 1 durante a transição da infância para adolescência. Revista da Escola de Enfermagem da USP, São Paulo, v. 52, nov. 2018. Disponível em:

$<$ https://www.scielo.br/scielo.php?script=sci_arttext\&pid=S0080-

62342018000100461\&lng=en\&tlng=en>. Acesso em: 17 de setembro de 2020.

CONSELHO REGIONAL DE ENFERMAGEM DE SANTA CATARINA. Protocolo de

Enfermagem - Hipertensão, diabetes e outros fatores associados a doenças cardiovasculares. Versão 1. Florianópolis, agosto de 2017. Disponível em: http://www.corensc.gov.br/wpcontent/uploads/2017/08/Protocolo-Enfermagem-vol1- v1-5-07082017-Versa\%CC\%83o-Ebook6.pdf. Acesso em: 26 de outubro 2020.

CRUZ, D.S.M.; COLLET, N.; ANDRADE, E.M.C.; NÓBREGA, V.M.; NÓBREGA,

M.M.L. Vivências de mães de crianças diabéticas. Escola Anna Nery, Rio de Janeiro, v.21, n.1, jan. 2017. Disponível em:

<https://www.scielo.br/scielo.php?script=sci_abstract\&pid=S141481452017000100202\&lng=en\&nr $\mathrm{m}=\mathrm{i}$ so\&tlng=pt>. Acesso em: 22 de outubro de 2020. 
CRUZ, D.S.M.; COLLET, N.; NÓBREGA, V.M. Qualidade de vida relacionada à saúde de adolescentes com DM 1- revisão integrativa. Ciência e Saúde Coletiva, Rio de Janeiro, v.23, n.3, p. 973-989. 2018. Disponível em:

< https://www.scielo.br/scielo.php?pid=S1413-81232018000300973\&script=sci_abstract\&tlng=pt>. Acesso em: 17 de outubro 2020.

CUNHA, G.H.; BARBOSA, R.V.A.; FONTENELE, M.S.M.; LIMA, M.A.C.; FRANCO,

K.B.; FECHINE, F.V. Resíduos de insulinoterapia produzidos no domicílio de diabético acompanhados na atenção primária. Revista Brasileira de Enfermagem, Brasília, v.70, n.3, p.646-653, mai./jun. 2017. Disponível em:

$<$ https://www.scielo.br/scielo.php?script=sci_arttext\&pid=S0034-

$71672017000300618 \&$ Ing=pt\&tlng=pt>. Acesso em: 14 de setembro de 2020.

\section{DISTRITO FEDERAL - SECRETÁRIA DE ESTADO DE SAÚDE. PROTOCOLO DE}

ENFERMAGEM Diabetes Mellitus. Brasília, janeiro de 2012. Disponível em: https://corendf.gov.br/site/wp-

content/uploads/2012/03/Protocolo\%20de\%20Fluxo\%20para\%20Diabetes.pdfAcess o em: 22 de outubro de 2020.

HERMES, T.S.V.; VIEIRA, C.S.; RODRIGUES, R.M.; TOSO, B.R.G.O.; FONSECA,

L.M.M. Criança diabética do tipo 1 e o convívio familiar: repercussões no manejo da doença. Saúde Debate, Rio de Janeiro, v.42, n.119, p.927-939, out./dez. 2018. Disponível em: <https://www.scielo.br/scielo.php?script=sci_abstract\&pid=S0103-

$11042018000400927 \&$ Ing=en\&nrm=iso\&tlng=pt>. Acesso em: 19 de outubro de 2020.

KANETO, L.A.; DAMIÃO, E.B.C.; VERISSIMO, M.L.R.; ROSSATO, L.M.;

TORIYAMA, A.T.M.; SZYLIT, R. Oficina educativa baseada em atividades lúdicas melhora o automonitoramento glicêmico entre crianças. Revista Latino-Americana de Enfermagem, São Paulo, V.26, out. 2018. Disponível em:

<https://www.scielo.br/scielo.php?pid=S0104- 11692018000100364\&script=sci_abstract\&tlng=pt>. Acesso em: 19 de outubro de 2020.

MENEZES, M.; LACERDA, L.L.V.; BORELLA, J.; ALVES, T.P. Qualidade de vida e

diabetes mellitus: autopercepção de adolescentes de uma cidade do Sul do Brasil. Psicologia: Teoria e Pesquisa, Brasília, v.35. 2019. Disponível em:

<https://www.scielo.br/scielo.php?pid=S1413- $81232018000300973 \&$ script=sci_abstract\&tlng=pt>. Acesso em: 15 de outubro de 2020.

OKIDO, A.C.C.; ALMEIDA, A.; VIEIRA, M.T.; NEVES, E.T.; MELLO, D.F.; LIMA,

R.A.G. As demandas de cuidado das crianças com diabetes mellitus tipo. Escola Anna Nery, Rio de Janeiro, v.21, n.2, 2017. Disponível em: 
$<$ https://www.scielo.br/scielo.php?script=sci_abstract\&pid=S1414-

$81452017000200206 \&$ Ing=pt\&nrm=iso\&tlng=pt>. Acesso em: 14 de setembro de 2020.

ORTIZ, L.O.M.; DAMIÃO, E.B.C.; ROSSATO, L.M.; L.M.; ALVES, R.C.P. Melhores

práticas de enfermagem em educação em diabetes à criança hospitalizada: uma revisão integrativa.

Revista Eletrônica de Enfermagem, Goiás, v.19. Disponível em: <https://www.revistas.ufg.br/fen/article/view/45655>. Acesso em: 21 de setembro de 2020.

PEREIRA, M.F.; FIGUEIREDO, A.M. A importância do diagnóstico da diabetes mellitus tipo 1 e 2 na infância. Salusvita, Bauru, v.26, n.2, p. 601-614. 2017.

Disponível em: <https://pesquisa.bvsalud.org/portal/resource/pt/biblio-1016313>. Acesso em: 14 de outubro de 2020.

PENNAFORT, V.P.S.; QUEIROZ, M.V.O.; NASCIMENTO, L.C.; GUEDES, M.V.C.

Rede de apoio social no cuidado familiar da criança com diabetes. Revista Brasileira de Enfermagem, Brasília, v.69, n.5, p. 912-919, set./out. 2016. Disponível em: $<$ https://www.scielo.br/scielo.php?script=sci_arttext\&pid=S0034-

$71672016000500912 \&$ Ing=pt\&tlng=pt>. Acesso em: 19 de outubro de 2020.

PIMENTEL, Isabela. "Taxa de incidência de diabetes cresceu 61,8\% nos últimos 10 anos". 2018. Disponível em: https://portal.fiocruz.br/noticia/taxa-de-incidencia-de- diabetes-cresceu-618-nosultimos-10-anos. Acesso em: 14 de setembro de 2020.

QUEIROZ, M.V.O.; BRITO, L.M.M.C.; PENNAFORT, V.P.S.; BEZERRA, F.S.M.

Sensibilizando a criança com diabetes para o cuidado de si: contribuição à prática educativa. Escola Anna Nery, Rio de Janeiro, v.20, n.2, p. 337-343, abr./jun. 2016. Disponível em : <https://www.scielo.br/scielo.php?pid=S1414- 81452016000200337\&script=sci_abstract\&tlng=pt>. Acesso em: 17 de setembro de 2020.

RIO DE JANEIRO, 07 mar.1997. O parecer de Relator $n^{\circ}$ 12/1997. Disponível em: http://www.cofen.gov.br/parecer-de-relator-no-012_4159.html. Acesso em: 22 de outubro de 2020.

ROSSANEIS, M.A.; ANDRADE, S.M.; GVOZD, R.; PISSINATI, P.S.C.; HADDAD,

M.C.L. Fatores associados ao controle glicêmico de pessoas com diabetes mellitus. Ciência e Saúde Coletiva, Rio de Janeiro, v.24, n.3, p. 997-1005. 2019. Disponível em: <https://www.scielo.br/scielo.php?pid=S1413- 81232019000300997\&script=sci_abstract $>$. Acesso em: 19 de outubro de 2020.

SANTOS, A.L.; MARCON, S.S.; TESTON, E.F.; BACK, I.R.; LINO, I.G.T.; BATISTA,V.C.; MATSUDA, L.M.; HADDAD, M.C.F.L. Adesão ao tratamento de diabetes mellitus e relação com a assistência na atenção primária. Revista Mineira deEnfermagem, Minas Gerais, v.24. 2020. Disponível em:

<http://reme.org.br/artigo/detalhes/1425>. Acesso em: 26 de outubro de 2020.

SOCIEDADE BRASILEIRA DE DIABETES. Diretrizes 2019-2020. Brasil, 2019. 
Disponível em: https://www.diabetes.org.br/profissionais/images/DIRETRIZES- COMPLETA-20192020.pdf. Acesso em: 14 de setembro de 2020.

VENANCIO, J.M.P.; LA BANCA, R.O.; RIBEIRO, C.A. Benefícios da participação em um acampamento no autocuidado de crianças e adolescentes com diabetes: percepção das mães. Escola Anna Nery, Rio de Janeiro, v.21, n.1, jan. 2017.

Disponível em:

<https://www.scielo.br/scielo.php?pid=S1414- 81452017000100204\&script=sci_abstract\&tlng=pt>. Acesso em: 19 de outubro de 2020.

WOLKERS, P.C.B.; MACEDO, J.C.B.; RODRIGUES, C.M.; FURTADO, M.C.C.;

MELLO, D.F. Atenção primária à criança com diabetes mellitus tipo 1: perspectiva de cuidadores. Acta Paulista de Enfermagem, São Paulo, v.30, n.5, p.451-457, set./out. 2017. Disponível em:

<https://www.scielo.br/scielo.php?script=sci_arttext\&pid=S0103$21002017000500451 \&$ lng=pt\&tlng=pt>. Acesso em: 22 de outubro de 2020.

WOLKERS, P.C.B.; PINA, J.C.; WERNET, M.; FURTADO, M.C.C.; MELLO, D.F.

Crianças com diabetes mellitus tipo 1: vulnerabilidade, cuidado e acesso à saúde. Texto e Contexto Enfermagem, Santa Catarina, v.28, abr. 2019. Disponível em:

<https://www.scielo.br/scielo.php?script=sci_arttext\&pid=S0104-07072019000100309\&tlng=en>. Acesso em: 14 de outubro de 2020.

WOLKERS, P.C.B.; YAKUWA, M.S.; PANCIERI, L.; RODRIGUES, C.M.; FURTADO,

M.C.C.; MELLO, D.F. Crianças com diabetes tipo 1: acesso aos imunológicos especiais e à puericultura. Revista da Escola de Enfermagem da USP, São Paulo, v.51, out. 2017. Disponível em:

$<$ https://www.scielo.br/scielo.php?script=sci_arttext\&pid=S0080-

$62342017000100448 \&$ Ing=en\&nrm=iso\&tlng=pt>. Acesso em: 19 de outubro de 2020. 